NIST NCSTAR 1-3B

Federal Building and Fire Safety Investigation of the World Trade Center Disaster

\title{
Steel Inventory and Identification
}

Stephen W. Banovic 


\section{Federal Building and Fire Safety Investigation of the World Trade Center Disaster}

\section{Steel Inventory and Identification}

Stephen W. Banovic

Materials Science and Engineering Laboratory

National Institute of Standards and Technology

September 2005

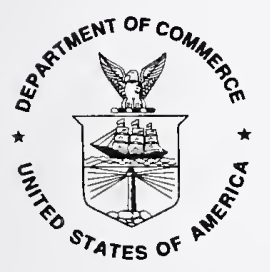

U.S. Department of Commerce

Carlos M. Gutierrez, Secretary

Technology Administration

Michelle O'Neill, Acting Under Secretary for Technology

National Institute of Standards and Technology

William Jeffrey, Director 


\title{
Disclaimer No. 1
}

Certain commercial entities, equipment, products, or materials are identified in this document in order to describe a procedure or concept adequately or to trace the history of the procedures and practices used. Such identification is not intended to imply recommendation, endorsement, or implication that the entities, products, materials, or equipment are necessarily the best available for the purpose. Nor does such identification imply a finding of fault or negligence by the National Institute of Standards and Technology.

\section{Disclaimer No. 2}

The policy of NIST is to use the International System of Units (metric units) in all publications. In this document, however, units are presented in metric units or the inch-pound system, whichever is prevalent in the discipline.

\section{Disclaimer No. 3}

Pursuant to section 7 of the National Construction Safety Team Act, the NIST Director has determined that certain evidence received by NIST in the course of this Investigation is "voluntarily provided safety-related information" that is "not directly related to the building failure being investigated" and that "disclosure of that information would inhibit the voluntary provision of that type of information" (15 USC 7306c).

In addition, a substantial portion of the evidence collected by NIST in the course of the Investigation has been provided to NIST under nondisclosure agreements.

\section{Disclaimer No. 4}

NIST takes no position as to whether the design or construction of a WTC building was compliant with any code since, due to the destruction of the WTC buildings, NIST could not verify the actual (or as-built) construction, the properties and condition of the materials used, or changes to the original construction made over the life of the buildings. In addition, NIST could not verify the interpretations of codes used by applicable authorities in determining compliance when implementing building codes. Where an Investigation report states whether a system was designed or installed as required by a code provision, NIST has documentary or anecdotal evidence indicating whether the requirement was met, or NIST has independently conducted tests or analyses indicating whether the requirement was met.

\section{$\underline{\text { Use in Legal Proceedings }}$}

No part of any report resulting from a NIST investigation into a structural failure or from an investigation under the National Construction Safety Team Act may be used in any suit or action for damages arising out of any matter mentioned in such report (15 USC 281a; as amended by P.L. 107-231).

National Institute of Standards and Technology National Construction Safety Team Act Report 1-3B Natl. Inst. Stand. Technol. Natl. Constr. Sfty. Tm. Act Rpt. 1-3B, 112 pages (September 2005) CODEN: NSPUE2

\author{
U.S. GOVERNMENT PRINTING OFFICE \\ WASHINGTON: 2005
}

For sale by the Superintendent of Documents, U.S. Government Printing Office

Internet: bookstore.gpo.gov - Phone: (202) 512-1800 - Fax: (202) 512-2250

Mail: Stop SSOP, Washington, DC 20402-0001 
As a result of the recovery efforts of the Structural Engineers Association of New York, Federal Emergency Management Agency/American Society of Civil Engineers, and the National Institute of Standards and Technology (NIST), NIST possesses 236 structural steel elements from the World Trade Center (WTC) buildings. These samples include full exterior column panels, core columns, portions of the floor truss members, channels used to attach the floor trusses to the interior columns, and other smaller structural components (e.g., bolts, diagonal bracing straps, aluminum façade). Many significant pieces were recovered from the impact and fire-affected floors. Additionally, the recovered structural elements have yielded sufficient representative samples, with respect to the determination of the quality and mechanical properties of the steel, for all 12 grades of exterior panel material, 2 grades of the core column material (representing 99 percent, by total number, of the columns), and both grades for the floor truss material. The lack of WTC 7 steel precludes tests on actual material from the structure; however, WTC 7 was constructed of three grades of conventional steel ( $36 \mathrm{ksi}, 42 \mathrm{ksi}$, and $50 \mathrm{ksi}$ ), and literature values may be used to estimate properties.

Keywords: Identification, inventory, recovered, steel, structural elements, World Trade Center. 
This page intentionally left blank. 


\section{TABLE OF CONTENTS}

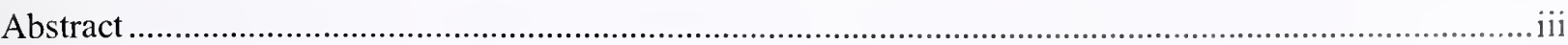

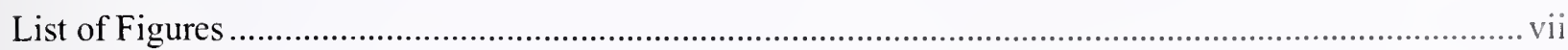

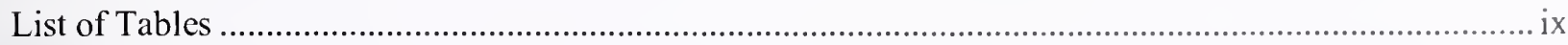

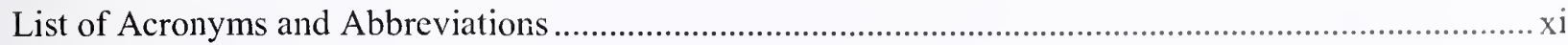

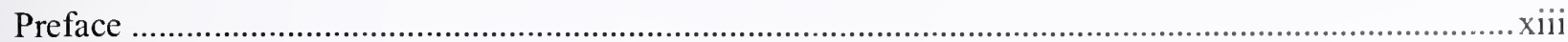

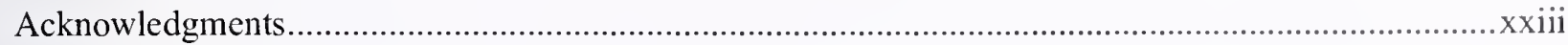

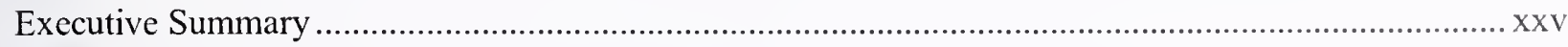

\section{Chapter 1}

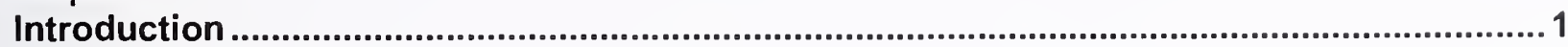

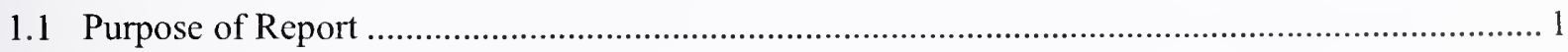

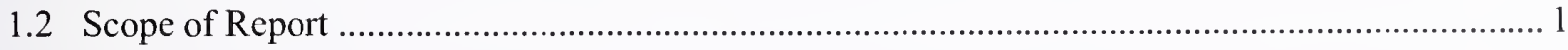

\section{Chapter 2}

Background Information Related to Recovery of WTC Structural Steel..............................3

\section{Chapter 3}

Structural Elements Recovered from the WTC Buildings................................................5

3.1 Present Location and Labeling of Structural Steel Elements .................................................... 5

3.2 Identification of WTC Structural Steel Elements .................................................................. 7

\section{Chapter 4}

Structural Steel Elements of Special Importance .......................................................4 47

4.1 Samples Located in or Around the Floors Impacted by the Airplane ........................................ 47

4.2 Samples Representing the Various Types of Steel Specified in the Design Drawings................. 49

\section{Chapter 5}

Summary.

Chapter 6

References

\section{Appendix A}

Data on Recovered WTC Steel 
This page intentionally left blank. 


\section{LIST OF FIGURES}

Figure $\mathrm{P}-1$. The cight projects in the federal building and fire safety investigation of the WTC disaster.

Figure 3-1. Characteristic "overall" view of the samples taken for cach piece received. Sample shown here is $\mathrm{C}-14$.....

Figure 3-2. Location of the exterior panels recovercd from the top third of WTC 1 and WTC 2.......... 9

Figure 3-3. Example of stampings on the interior basc of the middle column for each pancl.

Figure 3-4. Example of stampings placed on one end of a core column.

Figure 3-5. (a) Example of stamping placed on flangc indicating the column typc (120), and (b) schematic indicating the various plates corresponding to Table $3-5$.....

Figure 3-6. (a) Characteristic stenciling found on the lower portions of the cxterior column panels for sample C-14. (b) Charactcristic stenciling found on an interior core column for sample B-6152.

Figure 3-7. Schematic showing derrick divisions that hoisted the specific columns for (a) WTC 1 and (b) WTC 2. The " $\mathrm{x}$ " signifies the information that was not readable.

Figure 3-8. Schematic showing the sample M-10 as two separate exterior column panels, M-10a and $\mathrm{M}-10 \mathrm{~b}$.

Figure 3-9. Schematics displaying the various types of exterior column panels.

Figure 3-10. Exterior column panel maps indicating the portion of the specific exterior column panel section recovered from WTC 1 .

Figure 3-11. Exterior column panel maps indicating the portion of the specific exterior column panel section recovered from WTC 2 .

Figure 3-12. Core columns recovered from WTC 1. a) B-1011 (508A: 51-54), lower $2 \mathrm{ft}$ to $3 \mathrm{ft}$ of built-up box column, b) B-6152-1 (803A: 15-18), lower $3 \mathrm{ft}$ of built-up box column.

Figure 3-13. Core columns recovered from WTC 2. a) C-88a (801B: 80-83), lower $16 \mathrm{ft}$ of builtup box column and C-88b (801B: 77-80), upper $8 \mathrm{ft}$ of built-up box column.

Figure 3-14. Structural element composed of three wide flange sections bolted together. The component was found to be from the framed floor area outside of the core on the 107 th floor of WTC 1 (sample was C-26).

Figure 4-1. Interpreted column damage, from photographic evidence, to WTC 1, with overlay of samples in NIST's possession. Samples shown represent recovered portions. Core columns 603 and 605 are in the second row from the north face of WTC 1.

Figure 4-2. Interpreted column damage, from photographic evidence, to WTC 2, with overlay of samples in NIST's possession. 
This page intentionally left blank. 


\section{LIST OF TABLES}

Table P-1. Federal building and fire safety investigation of the WTC disaster............................... xiv

Table P-2. Public meetings and briefings of the WTC Investigation. xvii

Table 3-1. Identified exterior column panel pieces from WTC 1 and WTC 2 …........................... 8

Table 3-2. Partially identified extcrior column panel from WTC 1 or WTC 2 ................................ 9

Table 3-3. Identified pieces of core column material from WTC 1 and WTC 2 ............................ 10

Table 3-4. Other built-up box columns and wide flange sections from WTC 1 and WTC 2 with ambiguous stampings and/or markings.............................................................. 10

Table 3-5. Examples of column types with corresponding plate gauges. ......................................... 14

Table 3-6. Specified and observed minimum yield strengths for positively identified exterior

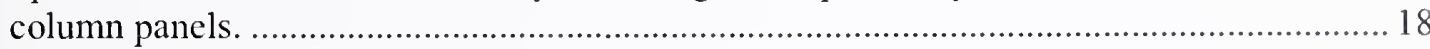

Table 3-7. Specified and observed column types for positively identified exterior column panels....... 19

Table 3-8. Specified minimum yield strengths from WTC 1 and WTC 2, along with the observed stampings, used to positively identify some exterior column panels.

Table 3-9. Specified column types of exterior panels from WTC 1 and WTC 2, along with the observed stampings, used to positively identify some exterior column panels....................2 21

Table 3-10. Information used to determine the identification of exterior panel ASCE-2 .....................22

Table 3-11. Information used to determine the identification of exterior panel M-2 ......................... 24

Table 4-1. Listing of recovered exterior column panels with specified minimum yield strengths and thickness for columns and spandrels. 51

Table 4-2. Strength/gauge combinations of perimeter columns recovered by NIST. 52

Table 4-3. Strength/gauge combinations of spandrels recovered by NIST. 
This page intentionally left blank. 


\section{LIST OF ACRONYMS AND ABBREVIATIONS}

\section{Acronyms}

\begin{tabular}{|c|c|}
\hline AISC & American Institute of Steel Construction \\
\hline ASCE & American Society of Civil Enginecrs \\
\hline ASTM & ASTM International \\
\hline BOCA & Building Officials and Codc Administrators \\
\hline $\mathrm{BOCA} / \mathrm{BBC}$ & BOCA Basic Building Code \\
\hline DTAP & dissemination and technical assistance program \\
\hline FEMA & Federal Emergency Management Agency \\
\hline GMS, LLP & Gilsanz Murray Steficek, LLP \\
\hline JFK & John F. Kennedy International Airport \\
\hline LERA & Leslie E. Robertson Associates \\
\hline LES & Large Eddy Simulation \\
\hline NIST & National Institute of Standards and Technology \\
\hline P.L. & Public Law \\
\hline PANYNJ & Port Authority of New York and New Jersey \\
\hline PONYA & Port of New York Authority \\
\hline $\mathrm{R} \& \mathrm{D}$ & research and development \\
\hline SEAoNY & Structural Engineers Association of New York \\
\hline USC & United States Code \\
\hline WF & $\begin{array}{l}\text { wide flange (a type of structural steel shape now usually called a W-shape). ASTM A } 6 \\
\text { defines them as "doubly-symmetric, wide-flange shapes with inside flange surfaces that } \\
\text { are substantially parallel." }\end{array}$ \\
\hline WTC & World Trade Center \\
\hline WTC 1 & World Trade Center 1 (North Tower) \\
\hline WTC 2 & World Trade Center 2 (South Tower) \\
\hline WTC 7 & World Trade Center 7 \\
\hline
\end{tabular}




\section{Abbreviations}

$\mathrm{ft}$

foot

$F_{y}$

yield strength (AISC usage)

in.

inch

$\mathrm{kg}$

kilogram

$\mathrm{ksi}$

1,000 pounds per square inch

m

meter 


\section{PREFACE}

\section{Genesis of This Investigation}

Immediately following the terrorist attack on the World Trade Center (WTC) on September 11, 2001, the Federal Emergeney Management Agency (FEMA) and the American Society of Civil Engineers bcgan planning a building performance study of the disaster. The weck of Oetober 7, as soon as the rescue and search efforts ceased, the Building Performance Study Team went to the sitc and began its assessment. This was to be a brief effort, as the study team consisted of experts who largely voluntecred their timc away from their other professional commitments. The Building Pcrformanee Study Team issued its report in May 2002, fulfilling its goal "to determine probable failure meehanisms and to identify areas of future investigation that could lead to practical measures for improving the damage resistance of buildings against such unforeseen events."

On August 21, 2002, with funding from the U.S. Congress through FEMA, the National Institute of Standards and Technology (NIST) announced its building and fire safety investigation of the WTC disaster. On October 1, 2002, the National Construction Safety Team Act (Public Law 107-231), was signed into law. The NIST WTC Investigation was conducted under the authority of the National Construction Safety Team Act.

The goals of the investigation of the WTC disaster were:

- To investigate the building construction, the materials used, and the technical conditions that contributed to the outcome of the WTC disaster.

- To serve as the basis for:

- Improvements in the way buildings are designed, constructed, maintained, and used:

- Improved tools and guidance for industry and safety officials;

- Recommended revisions to current codes, standards, and practices; and

- Improved public safety.

The specific objectives were:

1. Determine why and how WTC 1 and WTC 2 collapsed following the initial impacts of the aircraft and why and how WTC 7 collapsed;

2. Determine why the injuries and fatalities were so high or low depending on location, including all technical aspects of fire protection, occupant behavior, evacuation, and emergency response;

3. Determine what procedures and practices were used in the design, construction, operation, and maintenance of WTC 1,2, and 7; and

4. Identify, as specifically as possible, areas in current building and fire codes, standards, and practices that warrant revision. 
NIST is a nonregulatory agency of the U.S. Department of Commerce's Technology Administration. The purpose of NIST investigations is to improve the safety and structural integrity of buildings in the United States, and the focus is on fact finding. NIST investigative teams are authorized to assess building performance and emergency response and evacuation procedures in the wake of any building failure that has resulted in substantial loss of life or that posed significant potential of substantial loss of life. NIST does not have the statutory authority to make findings of fault nor negligence by individuals or organizations. Further, no part of any report resulting from a NIST investigation into a building failure or from an investigation under the National Construction Safety Team Act may be used in any suit or action for damages arising out of any matter mentioned in such report (15 USC 281a, as amended by Public Law 107-231).

\section{Organization of the Investigation}

The National Construction Safety Team for this Investigation, appointed by the then NIST Director, Dr. Arden L. Bement, Jr., was led by Dr. S. Shyam Sunder. Dr. William L. Grosshandler served as Associate Lead Investigator, Mr. Stephen A. Cauffman served as Program Manager for Administration, and Mr. Harold E. Nelson served on the team as a private sector expert. The Investigation included eight interdependent projects whose leaders comprised the remainder of the team. A detailed description of each of these eight projects is available at http:/wtc.nist.gov. The purpose of each project is summarized in Table $\mathrm{P}-1$, and the key interdependencies among the projects are illustrated in Fig. $\mathrm{P}-1$.

Table P-1. Federal building and fire safety investigation of the WTC disaster.

\begin{tabular}{|c|c|}
\hline Technical Area and Project Leader & $\begin{array}{l}\text { Project Purpose } \\
\end{array}$ \\
\hline $\begin{array}{l}\text { Analysis of Building and Fire Codes and } \\
\text { Practices; Project Leaders: Dr. H. S. Lew } \\
\text { and Mr. Richard W. Bukowski }\end{array}$ & $\begin{array}{l}\text { Document and analyze the code provisions, procedures, and } \\
\text { practices used in the design, construction, operation, and } \\
\text { maintenance of the structural, passive fire protection, and } \\
\text { emergency access and evacuation systems of WTC } 1,2 \text {, and } 7 \text {. }\end{array}$ \\
\hline $\begin{array}{l}\text { Baseline Structural Performance and } \\
\text { Aircraft Impact Damage Analysis; Project } \\
\text { Leader: Dr. Fahim H. Sadek }\end{array}$ & $\begin{array}{l}\text { Analyze the baseline performance of WTC } 1 \text { and WTC } 2 \text { under } \\
\text { design, service, and abnormal loads, and aircraft impact damage on } \\
\text { the structural, fire protection, and egress systems. }\end{array}$ \\
\hline $\begin{array}{l}\text { Mechanical and Metallurgical Analysis of } \\
\text { Structural Steel; Project Leader: Dr. Frank } \\
\text { W. Gayle }\end{array}$ & $\begin{array}{l}\text { Determine and analyze the mechanical and metallurgical properties } \\
\text { and quality of steel, weldments, and connections from steel } \\
\text { recovered from WTC } 1,2 \text {, and } 7 \text {. }\end{array}$ \\
\hline $\begin{array}{l}\text { ion of Active Fire Protection } \\
\text { Project Leader: Dr. David } \\
\text { Dr. William Grosshandler }\end{array}$ & $\begin{array}{l}\text { Investigate the performance of the active fire protection systems in } \\
\text { WTC } 1,2 \text {, and } 7 \text { and their role in fire control, emergency response, } \\
\text { and fate of occupants and responders. }\end{array}$ \\
\hline $\begin{array}{l}\text { Reconstruction of Thermal and Tenability } \\
\text { Environment; Project Leader: Dr. Richard } \\
\text { G. Gann }\end{array}$ & $\begin{array}{l}\text { Reconstruct the time-evolving temperature, thermal environment, } \\
\text { and smoke movement in WTC } 1,2 \text {, and } 7 \text { for use in evaluating the } \\
\text { structural performance of the buildings and behavior and fate of } \\
\text { occupants and responders. }\end{array}$ \\
\hline $\begin{array}{l}\text { Structural Fire Response and Collapse } \\
\text { Analysis; Project Leaders: Dr. John } \\
\text { L. Gross and Dr. Therese P. McAllister }\end{array}$ & $\begin{array}{l}\text { Analyze the response of the WTC towers to fires with and without } \\
\text { aircraft damage, the response of WTC } 7 \text { in fires, the performance } \\
\text { of composite steel-trussed floor systems, and determine the most } \\
\text { probable structural collapse sequence for WTC } 1,2 \text {, and } 7 \text {. }\end{array}$ \\
\hline $\begin{array}{l}\text { Occupant Behavior, Egress, and Emergency } \\
\text { Communications; Project Leader: Mr. Jason } \\
\text { D. Averill }\end{array}$ & $\begin{array}{l}\text { Analyze the behavior and fate of occupants and responders, both } \\
\text { those who survived and those who did not, and the performance of } \\
\text { the evacuation system. }\end{array}$ \\
\hline $\begin{array}{l}\text { Emergency Response Technologies and } \\
\text { Guidelines; Project Leader: Mr. J. Randall } \\
\text { Lawson }\end{array}$ & $\begin{array}{l}\text { Document the activities of the emergency responders from the time } \\
\text { of the terrorist attacks on WTC } 1 \text { and WTC } 2 \text { until the collapse of } \\
\text { WTC } 7 \text {, including practices followed and technologies used. }\end{array}$ \\
\hline
\end{tabular}




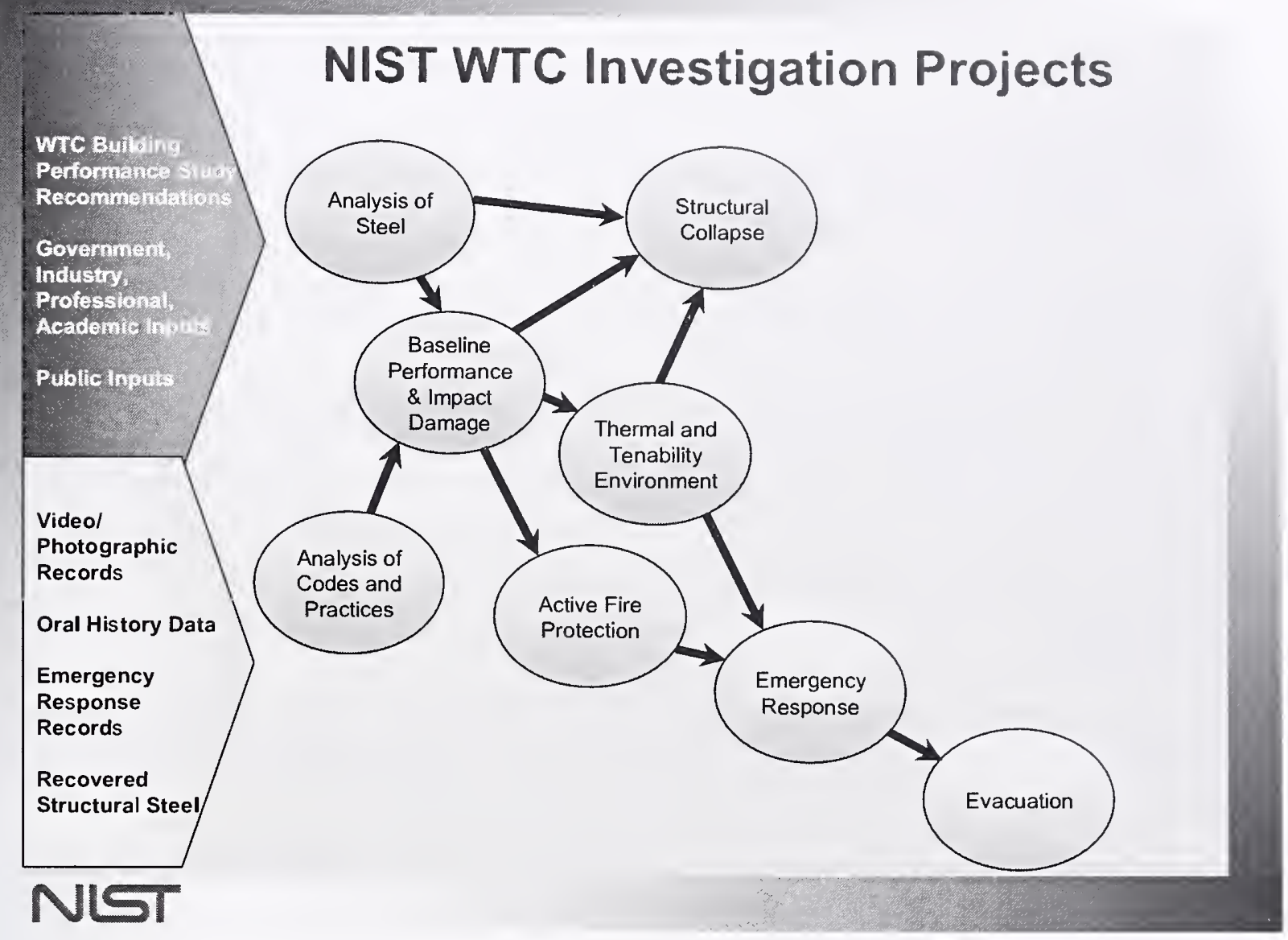

Figure P-1. The eight projects in the federal building and fire safety investigation of the WTC disaster.

\section{National Construction Safety Team Advisory Committee}

The NIST Director also established an advisory committee as mandated under the National Construction Safety Team Act. The initial members of the committee were appointed following a public solicitation. These were:

- Paul Fitzgerald, Executive Vice President (retired) FM Global, National Construction Safety Team Advisory Committee Chair

- John Barsom, President, Barsom Consulting, Ltd.

- John Bryan, Professor Emeritus, University of Maryland

- David Collins, President, The Preview Group, Inc.

- Glenn Corbett, Professor, John Jay College of Criminal Justice

- Philip DiNenno, President, Hughes Associates, Inc. 
- Robert Hanson, Professor Emeritus, University of Michigan

- Charles Thornton, Co-Chairman and Managing Principal, The Thornton-Tomasetti Group, Inc.

- Kathleen Tierney, Director, Natural Hazards Research and Applications Information Center, University of Colorado at Boulder

- Forman Williams, Director, Center for Energy Research, University of California at San Diego

This National Construction Safety Team Advisory Committee provided technical advice during the Investigation and commentary on drafts of the Investigation reports prior to their public release. NIST has benefited from the work of many people in the preparation of these reports, including the National Construction Safety Team Advisory Committee. The content of the reports and recommendations, however, are solely the responsibility of NIST.

\section{Public Outreach}

During the course of this Investigation, NIST held public briefings and meetings (listed in Table P-2) to solicit input from the public, present preliminary findings, and obtain comments on the direction and progress of the Investigation from the public and the Advisory Committee.

NIST maintained a publicly accessible Web site during this Investigation at http://wtc.nist.gov. The site contained extensive information on the background and progress of the Investigation.

\section{NIST's WTC Public-Private Response Plan}

The collapse of the WTC buildings has led to broad reexamination of how tall buildings are designed, constructed, maintained, and used, especially with regard to major events such as fires, natural disasters, and terrorist attacks. Reflecting the enhanced interest in effecting necessary change, NIST, with support from Congress and the Administration, has put in place a program, the goal of which is to develop and implement the standards, technology, and practices needed for cost-effective improvements to the safety and security of buildings and building occupants, including evacuation, emergency response procedures, and threat mitigation.

The strategy to meet this goal is a three-part NIST-led public-private response program that includes:

- A federal building and fire safety investigation to study the most probable factors that contributed to post-aircraft impact collapse of the WTC towers and the 47-story WTC 7 building, and the associated evacuation and cmergency response experience.

- A research and development (R\&D) program to (a) facilitate the implementation of recommendations resulting from the WTC Investigation, and (b) provide the technical basis for cost-effective improvements to national building and fire codes, standards, and practices that enhance the safety of buildings, their occupants, and emergency responders. 
Table P-2. Public meetings and briefings of the WTC Investigation.

\begin{tabular}{|c|c|c|}
\hline Date & Location & Principal Agenda \\
\hline June 24, 2002 & New York City, NY & $\begin{array}{l}\text { Public meeting: Public comments on the Draft Plan for the } \\
\text { pending WTC Investigation. }\end{array}$ \\
\hline August 21, 2002 & Gaithersburg, MD & Media briefing announcing the formal start of the Investigation. \\
\hline December 9, 2002 & Washington, DC & $\begin{array}{l}\text { Media briefing on release of the Public Update and NIST request } \\
\text { for photographs and videos. }\end{array}$ \\
\hline April 8, 2003 & New York City, NY & $\begin{array}{l}\text { Joint public forum with Columbia University on first-person } \\
\text { interviews. }\end{array}$ \\
\hline April 29-30, 2003 & Gaithersburg, MD & $\begin{array}{l}\text { NCST Advisory Committee meeting on plan for and progress on } \\
\text { WTC Investigation with a public comment session. }\end{array}$ \\
\hline May 7,2003 & New York City, NY & Media briefing on release of May 2003 Progress Report. \\
\hline August 26-27, 2003 & Gaithersburg, MD & $\begin{array}{l}\text { NCST Advisory Committee meeting on status of the WTC } \\
\text { investigation with a public comment session. }\end{array}$ \\
\hline September 17, 2003 & New York City, NY & $\begin{array}{l}\text { Media and public briefing on initiation of first-person data } \\
\text { collection projects. }\end{array}$ \\
\hline December 2-3, 2003 & Gaithersburg, MD & $\begin{array}{l}\text { NCST Advisory Committee meeting on status and initial results } \\
\text { and release of the Public Update with a public comment session. }\end{array}$ \\
\hline February 12,2004 & New York City, NY & $\begin{array}{l}\text { Public meeting on progress and preliminary findings with public } \\
\text { comments on issues to be considered in formulating final } \\
\text { recommendations. }\end{array}$ \\
\hline June 18,2004 & New York City, NY & Media/public briefing on release of June 2004 Progress Report. \\
\hline June $22-23,2004$ & Gaithersburg, MD & $\begin{array}{l}\text { NCST Advisory Committee meeting on the status of and } \\
\text { preliminary findings from the WTC Investigation with a public } \\
\text { comment session. }\end{array}$ \\
\hline August 24,2004 & Northbrook, IL & $\begin{array}{l}\text { Public viewing of standard fire resistance test of WTC floor } \\
\text { system at Underwriters Laboratories, Inc. }\end{array}$ \\
\hline October 19-20, 2004 & Gaithersburg, MD & $\begin{array}{l}\text { NCST Advisory Committee meeting on status and near complete } \\
\text { set of preliminary findings with a public comment session. }\end{array}$ \\
\hline November 22, 2004 & Gaithersburg, MD & $\begin{array}{l}\text { NCST Advisory Committee discussion on draft annual report to } \\
\text { Congress, a public comment session, and a closed session to } \\
\text { discuss pre-draft recommendations for WTC Investigation. }\end{array}$ \\
\hline April 5, 2005 & New York City, NY & $\begin{array}{l}\text { Media and public briefing on release of the probable collapse } \\
\text { sequence for the WTC towers and draft reports for the projects on } \\
\text { codes and practices, evacuation. and emergency response. }\end{array}$ \\
\hline June 23,2005 & New York City, NY & $\begin{array}{l}\text { Media and public briefing on release of all draft reports for the } \\
\text { WTC towers and draft recommendations for public comment. }\end{array}$ \\
\hline $\begin{array}{l}\text { September 12-13, } \\
2005\end{array}$ & Gaithersburg, MD & $\begin{array}{l}\text { NCST Advisory Committee meeting on disposition of public } \\
\text { comments and update to draft reports for the WTC towers. }\end{array}$ \\
\hline $\begin{array}{l}\text { September } 13-15 \text {, } \\
2005\end{array}$ & Gaithersburg, MD & $\begin{array}{l}\text { WTC Technical Conference for stakeholders and technical } \\
\text { community for dissemination of findings and recommendations } \\
\text { and opportunity for public to make technical comments. }\end{array}$ \\
\hline
\end{tabular}

- A dissemination and technical assistance program (DTAP) to (a) engage leaders of the construction and building community in ensuring timely adoption and widespread use of proposed changes to practices, standards, and codes resulting from the WTC Investigation and the R\&D program, and (b) provide practical guidance and tools to better prepare facility owners, contractors, architects, engineers, emergency responders, and regulatory authorities to respond to future disasters.

The desired outcomes are to make buildings, occupants, and first responders safer in future disaster events. 


\section{National Construction Safety Team Reports on the WTC Investigation}

A final report on the collapse of the WTC towers is being issued as NIST NCSTAR 1. A companion report on the collapse of WTC 7 is being issued as NIST NCSTAR 1A. The present report is one of a set that provides more detailed documentation of the Investigation findings and the means by which these technical results were achieved. As such, it is part of the archival record of this Investigation. The titles of the full set of Investigation publications are:

NIST (National Institute of Standards and Technology). 2005. Federal Brilding and Fire Safety Investigation of the World Trade Center Disaster: Final Report on the Collapse of the World Trade Center Towers. NIST NCSTAR 1. Gaithersburg, MD, September.

NIST (National Institute of Standards and Technology). 2006. Federal Building and Fire Safety Investigation of the World Trade Center Disaster: Final Report on the Collapse of World Trade Center 7. NIST NCSTAR 1A. Gaithersburg, MD.

Lew, H. S., R. W. Bukowski, and N. J. Carino. 2005. Federal Building and Fire Safety Investigation of the World Trade Center Disaster: Design, Construction, and Maintenance of Strictural and Life Safety Systems. NIST NCSTAR 1-1. National Institute of Standards and Technology. Gaithersburg, MD, September.

Fanella, D. A., A. T. Derecho, and S. K. Ghosh. 2005. Federal Building and Fire Safety Investigation of the World Trade Center Disaster: Design and Construction of Structural Systems. NIST NCSTAR 1-1A. National Institute of Standards and Technology. Gaithersburg, MD, September.

Ghosh, S. K., and X. Liang. 2005. Federal Bnilding and Fire Safety Investigation of the World Trade Center Disaster: Comparison of Building Code Structural Requirentents. NIST NCSTAR 1-1B. National Institute of Standards and Technology. Gaithersburg, MD, September.

Fanella, D. A., A. T. Derecho, and S. K. Ghosh. 2005. Federal Building and Fire Safety Investigation of the World Trade Center Disaster: Maintenance and Modifications to Structural Systems. NIST NCSTAR 1-1C. National Institute of Standards and Technology. Gaithersburg, MD, September.

Grill, R. A., and D. A. Johnson. 2005. Federal Building and Fire Safety Investigation of the World Trade Center Disaster: Fire Protection and Life Safety Provisions Applied to the Design and Construction of World Trade Center 1, 2, and 7 and Post-Construction Provisions Applied after Occupancy. NIST NCSTAR 1-1D. National Institute of Standards and Technology. Gaithersburg, $\mathrm{MD}$, September.

Razza, J. C., and R. A. Grill. 2005. Federal Building and Fire Safety Investigation of the World Trade Center Disaster: Comparison of Codes, Standards, and Practices in Use at the Time of the Design and Construction of World Trade Center 1, 2, and 7. NIST NCSTAR 1-1E. National Institute of Standards and Technology. Gaithersburg, MD, September.

Grill, R. A., D. A. Johnson, and D. A. Fanella. 2005. Federal Building and Fire Safety Investigation of the World Trade Center Disaster: Comparison of the 1968 and Current (2003) New 
York City Building Code Provisions. NIST NCSTAR 1-1F. National Institutc of Standards and Technology. Gaithcrsburg, MD, September.

Grill, R. A., and D. A. Johnson. 2005. Federal Building and Fire Safety Investigation of the World Trade Center Disaster: Amendnemts to tlre Fire Protection and Life Safety Provisions of the New York City Building Code by Local Laws Adopted While World Trade Center 1, 2, and 7 Were in Use. NIST NCSTAR 1-1G. National Institutc of Standards and Tcchnology. Gaithersburg, MD, Septembcr.

Grill, R. A., and D. A. Johnson. 2005. Federal Building and Fire Safety Investigation of the World Trade Center Disaster: Post-Constmction Modifications to Fire Protection and Life Safety Systems of World Trade Center 1 and 2. NIST NCSTAR 1-1H. National Institutc of Standards and Technology. Gaithersburg, MD, September.

Grill, R. A., D. A. Johnson, and D. A. Fanella. 2005. Federal Building and Fire Safety Investigation of the World Trade Center Disaster: Post-Construction Modifications to Fire Protection, Life Safety, and Structural Systems of World Trade Center 7. NIST NCSTAR 1-1I. National Institute of Standards and Technology. Gaithersburg, MD, September.

Grill, R. A., and D. A. Johnson. 2005. Federal Building and Fire Safety Investigation of the World Trade Center Disaster: Design, Installation, and Operation of Fuel Systen for Emergency Power in World Trade Center 7. NIST NCSTAR 1-1J. National Institutc of Standards and Technology. Gaithersburg, MD, September.

Sadek, F. 2005. Federal Building and Fire Safety Investigation of the World Trade Center Disaster: Baseline Structural Performance and Aircraft Impact Damage Analysis of the World Trade Center Towers. NIST NCSTAR 1-2. National Institute of Standards and Technology. Gaithersburg, MD, September.

Faschan, W. J., and R. B. Garlock. 2005. Federal Building and Fire Safety Investigation of the World Trade Center Disaster: Reference Structural Models and Baseline Performance Analysis of the World Trade Center Towers. NIST NCSTAR 1-2A. National Institute of Standards and Technology. Gaithersburg, MD, September.

Kirkpatrick, S. W., R. T. Bocchieri, F. Sadek, R. A. MacNeill, S. Holmes, B. D. Peterson, R. W. Cilke, C. Navarro. 2005. Federal Building and Fire Safety Investigation of the World Trade Center Disaster: Analysis of Aircraft Impacts into the World Trade Center Towers, NIST

NCSTAR 1-2B. National Institute of Standards and Technology. Gaithersburg, MD, September.

Gayle, F. W., R. J. Fields, W. E. Luecke, S. W. Banovic, T. Foecke, C. N. McCowan, T. A. Siewert, and J. D. McColskey. 2005. Federal Building and Fire Safety Investigation of the World Trade Center Disaster: Mechanical and Metallurgical Analys is of Structural Steel. NIST NCSTAR 1-3. National Institute of Standards and Technology. Gaithersburg, MD, September.

Luecke, W. E., T. A. Siewert, and F. W. Gayle. 2005. Federal Building and Fire Safety Investigation of the World Trade Center Disaster: Contemporaneous Structural Steel Specifications. NIST Special Publication 1-3A. National Institute of Standards and Technology. Gaithersburg, MD, September. 
Banovic, S. W. 2005. Federal Building and Fire Safety Imvestigation of the World Trade Center Disaster: Steel Inventory and Identification. NIST NCSTAR 1-3B. National Institute of Standards and Technology. Gaithersburg, MD, September.

Banovic, S. W., and T. Foecke. 2005. Federal Building and Fire Safety Investigation of the World Trade Center Disaster: Damage and Failmre Modes of Strnctural Steel Components. NIST NCSTAR 1-3C. National Institute of Standards and Technology. Gaithersburg, MD, September.

Luecke, W. E., J. D. McColskey, C. N. McCowan, S. W. Banovic, R. J. Fields, T. Foecke, T. A. Siewert, and F. W. Gayle. 2005. Federal Building and Fire Safety Investigation of the World Trade Center Disaster: Mechanical Properties of Structural Steels. NIST NCSTAR 1-3D. National Institute of Standards and Technology. Gaithersburg, MD, September.

Banovic, S. W., C. N. McCowan, and W. E. Luecke. 2005. Federal Building and Fire Safety Investigation of the World Trade Center Disaster: Physical Properties of Structural Steels. NIST NCSTAR 1-3E. National Institute of Standards and Technology. Gaithersburg, MD, September.

Evans, D. D., R. D. Peacock, E. D. Kuligowski, W. S. Dols, and W. L. Grosshandler. 2005. Federal Building and Fire Safety Investigation of the World Trade Center Disaster: Active Fire Protection Systems. NIST NCSTAR 1-4. National Institute of Standards and Technology. Gaithersburg, MD, September.

Kuligowski, E. D., D. D. Evans, and R. D. Peacock. 2005. Federal Bnilding and Fire Safety Investigation of the World Trade Center Disaster: Post-Construction Fires Prior to September 11, 2001. NIST NCSTAR 1-4A. National Institute of Standards and Technology. Gaithersburg, MD, September.

Hopkins, M., J. Schoenrock, and E. Budnick. 2005. Federal Building and Fire Safety Investigation of the World Trade Center Disaster: Fire Sinpression Systems. NIST NCSTAR 1-4B. National Institute of Standards and Technology. Gaithersburg, MD, September.

Keough, R. J., and R. A. Grill. 2005. Federal Building and Fire Safety Investigation of the World Trade Center Disaster: Fire Alarm Systenis. NIST NCSTAR 1-4C. National Institute of Standards and Technology. Gaithersburg, MD, September.

Ferreira, M. J., and S. M. Strege. 2005. Federal Building and Fire Safety Investigation of the World Trade Center Disaster: Smoke Management Systems. NIST NCSTAR 1-4D. National Institute of Standards and Technology. Gaithersburg, MD, September.

Gann, R. G., A. Hamins, K. B. McGrattan, G. W. Mulholland, H. E. Nelson, T. J. Ohlemiller, W. M. Pitts, and K. R. Prasad. 2005. Federal Building and Fire Safety Investigation of the World Trade Center Disaster: Reconstruction of the Fires in the World Trade Center Towers. NIST NCSTAR 1-5. National Institute of Standards and Technology. Gaithersburg, MD, September.

Pitts, W. M., K. M. Butler, and V. Junker. 2005. Federal Building and Fire Safety Investigation of the World Trade Center Disaster: Visual Evidence, Damage Estimates, and Timeline Analysis. NIST NCSTAR 1-5A. National Institute of Standards and Technology. Gaithersburg, MD, September. 
Hamins, A., A. Maranghides, K. B. McGrattan, E. Johnsson, T. J. Ohlcmiller, M. Donnclly, J. Yang, G. Mulholland, K. R. Prasad, S. Kukuck, R. Anlcitner and T. McAllister. 2005. Federal Building and Fire Safety Investigation of the World Trade Center Disaster: Experiments and Modeling of Structural Steel Elements Exposed to Fire. NIST NCSTAR 1-5B. National Institute of Standards and Technology. Gaithersburg, MD, Scptember.

Ohlemiller, T. J., G. W. Mulholland, A. Maranghides, J. J. Filliben, and R. G. Gann. 2005. Federal Building and Fire Safety Investigation of the World Trade Center Disaster: Fire Tests of Single Office Workstations. NIST NCSTAR 1-5C. National Institutc of Standards and Technology. Gaithersburg, MD, September.

Gann, R. G., M. A. Riley, J. M. Repp, A. S. Whittaker, A. M. Reinhorn, and P. A. Hough. 2005. Federal Building and Fire Safety Investigation of the World Trade Center Disaster: Reaction of Ceiling Tile Systems to Shocks. NIST NCSTAR 1-5D. National Institute of Standards and Technology. Gaithersburg, MD, September.

Hamins, A., A. Maranghides, K. B. McGrattan, T. J. Ohlcmiller, and R. Anleitner. 2005. Federal Building and Fire Safety Investigation of the World Trade Center Disaster: Experiments and Modeling of Multiple Workstations Burning in a Compartment. NIST NCSTAR 1-5E. National Institute of Standards and Technology. Gaithersburg, MD, Septembcr.

McGrattan, K. B., C. Bouldin, and G. Forney. 2005. Federal Building and Fire Safety Investigation of the World Trade Center Disaster: Computer Simulation of the Fires in the World Trade Center Towers. NIST NCSTAR 1-5F. National Institute of Standards and Technology. Gaithersburg, MD, September.

Prasad, K. R., and H. R. Baum. 2005. Federal Building and Fire Safety Investigation of the World Trade Center Disaster: Fire Structure Interface and Thermal Response of the World Trade Center Towers. NIST NCSTAR 1-5G. National Institute of Standards and Tcchnology. Gaithersburg, MD, September.

Gross, J. L., and T. McAllister. 2005. Federal Building and Fire Safety Investigation of the World Trade Center Disaster: Structural Fire Response and Probable Collapse Sequence of the World Trade Center Towers. NIST NCSTAR 1-6. National Institute of Standards and Technology. Gaithersburg, MD. September.

Carino, N. J., M. A. Starnes, J. L. Gross, J. C. Yang, S. Kukuck, K. R. Prasad, and R. W. Bukowski. 2005. Federal Building and Fire Safety Investigation of the World Trade Center Disaster: Passive Fire Protection. NIST NCSTAR 1-6A. National Institute of Standards and Technology. Gaithersburg, MD, September.

Gross, J., F. Hervey, M. Izydorek, J. Mammoser, and J. Treadway. 2005. Federal Building and Fire Safety Investigation of the World Trade Center Disaster: Fire Resistance Tests of Floor Truss Systems. NIST NCSTAR 1-6B. National Institute of Standards and Technology. Gaithersburg, MD, September.

Zarghamee, M. S., S. Bolourchi, D. W. Eggers, Ö. O. Erbay, F. W. Kan, Y. Kitane, A. A. Liepins, M. Mudlock, W. I. Naguib, R. P. Ojdrovic, A. T. Sarawit, P. R Barrett, J. L. Gross, and 
T. P. McAllister. 2005. Federal Building and Fire Safety Investigation of the World Trade Center Disaster: Component, Connection, and Subsystem Structural Analysis. NIST NCSTAR 1-6C.

National Institute of Standards and Technology. Gaithersburg, MD, September.

Zarghamee, M. S., Y. Kitane, Ö. O. Erbay, T. P. McAllister, and J. L. Gross. 2005. Federal Building and Fire Safety Investigation of the World Trade Center Disaster: Global Strictural Analysis of the Response of the World Trade Center Towers to Impact Damage and Fire. NIST NCSTAR 1-6D. National Institute of Standards and Technology. Gaithersburg, MD, September.

McAllister, T., R. W. Bukowski, R. G. Gann, J. L. Gross, K. B. McGrattan, H. E. Nelson, L. Phan, W. M. Pitts, K. R. Prasad, F. Sadek. 2006. Federal Building and Fire Safety Investigation of the World Trade Center Disaster: Structural Fire Response and Probable Collapse Sequence of World Trade Center 7. (Provisional). NIST NCSTAR 1-6E. National Institute of Standards and Technology. Gaithersburg, MD.

Gilsanz, R., V. Arbitrio, C. Anders, D. Chlebus, K. Ezzeldin, W. Guo, P. Moloney, A. Montalva, J. Oh, K. Rubenacker. 2006. Federal Building and Fire Safety Investigation of the World Trade Center Disaster: Structural Analysis of the Response of World Trade Center 7 to Debris Damage and Fire. (Provisional). NIST NCSTAR 1-6F. National Institute of Standards and Technology. Gaithersburg, MD.

Kim, W. 2006. Federal Building and Fire Safety Investigation of the World Trade Center Disaster: Analysis of September 11, 2001, Seismogram Data. (Provisional). NIST NCSTAR 1-6G. National Institute of Standards and Technology. Gaithersburg, MD.

Nelson, K. 2006. Federal Building and Fire Safety Investigation of the World Trade Center Disaster: The Con Ed Substation in World Trade Center 7. (Provisional). NIST NCSTAR 1-6H. National Institute of Standards and Technology. Gaithersburg, MD.

Averill, J. D., D. S. Mileti, R. D. Peacock, E. D. Kuligowski, N. Groner, G. Proulx, P. A. Reneke, and H. E. Nelson. 2005. Federal Building and Fire Safety Investigation of the World Trade Center Disaster: Occupant Behavior, Egress, and Emergency Communication. NIST NCSTAR 1-7. National Institute of Standards and Technology. Gaithersburg, MD, September.

Fahy, R., and G. Proulx. 2005. Federal Building and Fire Safety Investigation of the World Trade Center Disaster: Analysis of Published Accounts of the World Trade Center Evacuation. NIST NCSTAR 1-7A. National Institute of Standards and Technology. Gaithersburg, MD, September.

Zmud, J. 2005. Federal Building and Fire Safety Investigation of the World Trade Center Disaster: Technical Documentation for Sirvey Administration. NIST NCSTAR 1-7B. National Institute of Standards and Technology. Gaithersburg, MD, September.

Lawson, J. R., and R. L. Vettori. 2005. Federal Burilding and Fire Safety Investigation of the World Trade Center Disaster: The Enrergency Response Operations. NIST NCSTAR 1-8. National Institute of Standards and Technology. Gaithersburg, MD, September. 


\section{ACKNOWLEDGMENTS}

National Institute of Standards and Technology (NIST) thanks these voluntcers of the Structural Engineers Association of New York for their cfforts in the recovery of the stcel components: Amit Bandyopadhyay, Anamaria Bonilla, Peter Chipchase, Anthony Chuliver, Edward DcPaola, Louis Errichiello, James Fahey, Ramon Gilsanz, Jeffrey Hartman, David Hoy, Dcan Koutsoubis, Andrew McConnell, Rajani Nair, Alan Rosa, David Sharp, Gary Stcficck, and Kevin Terry. Countlcss hours wcre unselfishly spent in the recovery yards searching for these invaluable pieces that arc an integral component of this investigation. Further, the following people are recognized for their outstanding leadership roles throughout the recovery effort: Ramon Gilsanz, primary leader of the recovery cffort; David Sharp, coordinator of volunteer activities and author of the guide used for the selection of suitable pieces; and Audrey Massa of Federal Emergency Management Agcncy (FEMA), leader for documentation and cataloguing of efforts and pieces to be saved.

The FEMA/American Society of Civil Engineers Building Performance Asscssment Team; Professor A. Astaneh-Asl of the University of California, Berkeley, California; and the National Science Foundation are also acknowledged for their help in the rccovery effort.

Blanford Land Development Corporation; Hugo Neu Schnitzer, Inc.; and Mctal Managemcnt, Inc. are thanked for the initial storing of the structural stcel during the clean-up effort of the World Trade Center site and for their assistance and patience during the review, abatement, and final removal of pieces of interest to the investigation.

NIST also thanks the Port Authority of New York and New Jersey for its assistance in surveying, sectioning, and transporting the technically significant structural steel collected by the Port Authority and stored at John F. Kennedy International Airport. 
This page intentionally left blank. 


\section{EXECUTIVE SUMMARY}

As a result of the recovery efforts of the Structural Engineers Association of New York, Fcdcral Emergency Management Agency/American Socicty of Civil Engincers, and the National Institute of Standards and Technology (NIST), NIST posscsses 236 structural stcel elements from the World Tradc Center (WTC) buildings. These pieces represent a small fraction of the enormous amount of stccl examined at the various recovery yards where the debris was sent as the WTC site was clearcd. Elcments located in or near the impact zone and fire damaged regions wcre emphasized in the selection process. These samples include full extcrior column panels, core columns, portions of the floor truss members, channels used to attach the floor trusses to the interior columns, and other smaller structural components (e.g., bolts, diagonal bracing straps, aluminum façade, etc.). These structural components were used for evaluation and/or testing relative to the fire and structural response of the WTC buildings.

Upon arrival at NIST, the samples were catalogued, documented, and when possible, identified as to their precise, as-built location within the buildings. The vast majority of the structural components are from WTC 1 and WTC 2. It is cstimated that roughly 0.25 percent to 0.5 percent of the 200,000 tons of steel used in the construction of the two towers was recovered. The following lists the recovered structural steel elements:

- Out of the 90 exterior panels recovered, the as-built location of 42 distinct sections was unambiguously identified within WTC 1 and WTC 2:

- 26 panels from WTC 1:22 from or near the impact floors, 4 hit directly by the airplane,

- 16 panels from WTC 2: 4 near the impact floors.

- Out of the 55 wide flange sections and built-up box sections recovered, 12 core columns were positively identified from WTC 1 and WTC 2, including:

- Two columns from the fire floors of WTC 1,

- Two columns from the impact zone of WTC 2.

- 23 pieces of floor truss material from WTC 1 and WTC 2 were recovered; however. the asbuilt location of the trusses within the buildings could not be identified.

- 25 pieces of channel material that connected the floor trusses to the core columns in WTC 1 and WTC 2 were recovered; however, the as-built location of the channels within the buildings could not be identified.

- One piece of floor framing from outside the core of the 107 th floor of WTC 1.

- Seven coupons from WTC 5 were removed in the field and sent to NIST.

- $\quad$ No pieces could be unambiguously identified as being from WTC 7. 
The design drawings for WTC 1 and WTC 2 designate 14 different grades (or strengths) of steel for the exterior panels, four different grades for the core columns, and two grades for the floor trusses. From the recovered and identified columns, whether perimeter or core, a one to one correlation was observed between the minimum yield strength specified by the design drawings and the observed stampings and/or stencilings on the samples, with the exception of the $85 \mathrm{ksi}$ and $90 \mathrm{ksi}$ material that was substituted with 100 ksi plate. The recovered structural elements yielded sufficient representative samples for the following:

- All 12 grades of exterior panel material,

- Two grades of the core column material (representing 99 percent, by total number, of the columns),

- Both grades for the floor truss material.

This collection of steel from the WTC towers is sufficient for determining the quality of the steel and for determining mechanical properties as input to models of building performance. The lack of WTC 7 steel precludes tests on actual material from the structure; however, WTC 7 was constructed of three grades of conventional steel ( $36 \mathrm{ksi}, 42 \mathrm{ksi}$, and $50 \mathrm{ksi}$ ), and literature values may be used to estimate properties. 


\section{Chapter 1 \\ INTRODUCTION}

\section{$1.1 \quad$ PURPOSE OF REPORT}

The purpose of analyzing structural stccl available from World Tradc Center (WTC) 1, 2, and 7 is to determine the mctallurgical and mechanical propcrties and quality of the metal, weldments, and connections and to provide these data for other analyses in the National Institute of Standards and Technology (NIST) Investigation. The properties determined wcre uscd in two ways:

- Properties were correlatcd with the design requirements of the buildings to determine if the specified steel was in place in the towers.

- Properties were supplied as input for models of building performance.

\subsection{SCOPE OF REPORT}

The scope of this report covers the inventory and identification of steels recovered from the WTC buildings. Approximately 236 pieces of WTC steel were available for study at NIST. These pieces represent a small fraction of the steel examined at the various recovery yards where the steel was sent as the WTC site was cleared.

For reference throughout this report, NIST NCSTAR 1-3 $\mathrm{A}^{1}$ describes the tower structure and critical structural elements discussed below. This includes the structural design and properties specified by the structural engineers for columns, floor systems, and connections. Further, NIST NCSTAR 1-3A also discusses the contemporaneous (late 1960s era) specifications for various types and grades of stcel designated by ASTM International, the American Institute of Steel Construction (AISC), and other national and international organizations. It also includes information from numerous suppliers of the steel for the structure. 1 This reference is to one of the companion documents from this Investigation. A list of these documents appears in the Preface
to this report. 
This page intentionally left blank. 


\section{Chapter 2 \\ BACKGROUND INFORMATION RELATED TO RECOVERY OF WTC STRUCTURAL STEEL}

Beginning in October 2001, members of the Fcderal Emcrgency Management Agcncy (FEMA), American Society of Civil Engineers (ASCE), Building Pcrformance Study (BPS) Tcam, members of the Structural Engineers Association of New York (SEAoNY), and Professor A. Astaneh-Asl of the University of California, Berkeley, California (Astaneh-Asl 2002), with support from the National Science Foundation, began work to identify and collect World Trade Center (WTC) structural stcel from the various recovery yards where debris, including the steel, was takcn during the cleanup effort.

Dr. J. Gross, a structural engineer at the National Institute of Standards and Technology (NIST) and a member of the FEMA/ASCE BPS Team, was involved in these early efforts.

There were four major sites where debris from the WTC buildings was shippcd during the clean-up effort in which the volunteers worked. These were:

- Hugo Neu Schnitzer, Inc., Fresh Kills Landfill in Staten Island, New Jersey;

- Hugo Neu Schnitzer East, Inc., Claremont Terminal in Jersey City, New Jersey;

- Metal Management, Inc., in Newark, New Jersey; and

- Blanford and Co. in Keasbey, New Jersey.

The volunteers searched through unsorted piles of steel and other debris for pieces from the WTC buildings, specifically searching for (McAllister 2002):

- Exterior column panels and interior core columns from WTC 1 and WTC 2 that were exposed to fire and/or impacted by the aircraft;

- Exterior column panels and interior core columns from WTC 1 and WTC 2 directly above and below the impact zones;

- $\quad$ Badly burned pieces from WTC 7;

- Connections from WTC 1, 2, and 7 (e.g., seat connections, single-shear plates, and column splices);

- Bolts in all conditions;

- Floor trusses, including stiffeners, seats, and other components; and

- Any pieces that in the engineers' professional opinion might be useful. 
Once identified for recovery, the samples were marked as "SAVE" and given an alphanumeric code relative to the recovery yard from which they came and an accession number. Some pieces were not saved in their entirety, but instead, small portions were removed, hereafter called coupons. (Coupons were also removed in the field for WTC 5, held at Gilsanz Murray Steficek, LLP [GMS, LLP], and later brought to NIST.)

Facing concern that the identified steel may not be properly preserved in the recovery yards, NIST arranged for the steel to be shipped to its campus in Gaithersburg, Maryland, starting in March 2002. Professor Astaneh-Asl also granted NIST permission to take custody of the steel that he had personally marked. Before the samples were shipped to the NIST campus, environmental testing for asbestos and analysis of the paint for lead was conducted. Volunteers from SEAoNY, with assistance from additional NIST personnel, continued their presence at the recovery yards and identified, catalogued, and shipped steel specimens to NIST through October 2002. The structural components recovered now constitute the material base from which samples are being removed for further evaluation and or testing relative to the fire and structural response of the WTC buildings as part of the WTC Investigation.

Structural steel elements were also collected and held by the Port Authority of New York and New Jersey (PANYNJ) in Hanger 17 located at John F. Kennedy (JFK) International Airport. The main goal of the PANYNJ project was to decontaminate and preserve the steel, as well as other WTC artifacts, for future exhibits and memorials. A complete listing of the pieces held by PANYNJ can be found in the Preservation and Inventory Report prepared by Voorsanger and Associates Architects, PC. ${ }^{2}$ NIST personnel visited the hanger and identified 12 additional pieces that were considered important to its Investigation. Six of these samples were moved whole to the Gaithersburg campus. The remaining pieces had portions removed and sent to NIST, with the bulk of the structural element remaining at JFK International Airport.

2 Voorsanger and Associates Architects, PC. 2002. WTC Archives Interim Storage Facility, JFK International Airport: Preservation and Inventory Report, Draft 2. New York, NY, November. 


\section{Chapter 3 \\ Structural ELEMENTS RECOVERED FROM THE WTC BUILDINGS}

\subsection{PRESENT LOCATION AND LABELING OF STRUCTURAL STEEL ELEMENTS}

At present, the National Institute of Standards and Technology (NIST) possesses 236 labcled samples from the World Trade Center (WTC) buildings. While the majority of the NIST-hcld samplcs residc on the Gaithersburg campus, some samples were shipped to the Boulder, Colorado, campus for mechanical property testing following initial documentation.

As samples were delivered, overall images of the pieces were taken for record-keeping purposes. An example is shown in Fig. 3-1. Samples are identified by their original alphanumeric idcntification codes assigned by Structural Engineers Association of New York to be consistent with the Federal Emergency Management Agency report. However, there were cases in which two different codes were found on one piece. In these instances, if the pieces were already undergoing documentation procedurcs, the first code noted was used. Samples that arrived lacking a code were labeled as part of the U series. Additionally, samples brought from Hanger 17 at John F. Kennedy International Airport maintained their "B"-series labels provided in the Voorsanger report. ${ }^{2}$

Appendix A, Table A-1, is a complete list of each sample received, in alphanumeric order, with its classification, a brief description of the component, and the location of the piece on the NIST campus. These samples range from full exterior column panels to pieces of bolts and bags of glass and other debris fragments. The pieces were classified into one of eight categories:

\section{Classification}

Exterior column panel sections (flat wall or corner)

Bowtie pieces

Rectangular built-up box column (not perimeter column)

Wide flange sections

Floor trusses

Channels

Coupons from WTC 5

Miscellaneous (isolated bolts, floor hanger components, or other)

$\begin{array}{cc}\text { No. of Pieces } & \text { Symbol } \\ 94 & \text { C, CC, or Cn } \\ 2 & \text { BT } \\ 11 & \text { RB } \\ 44 & \text { W } \\ 23 & \mathrm{~J} \\ 25 & \mathrm{Ch} \\ 7 & \mathrm{Cn} 5 \\ 30 & \text { B,H.O }\end{array}$

Tables A-2 through A-11 list the pieces separated by type, and Figs. A-1 through A-14 displays characteristic photographs of the various pieces. 

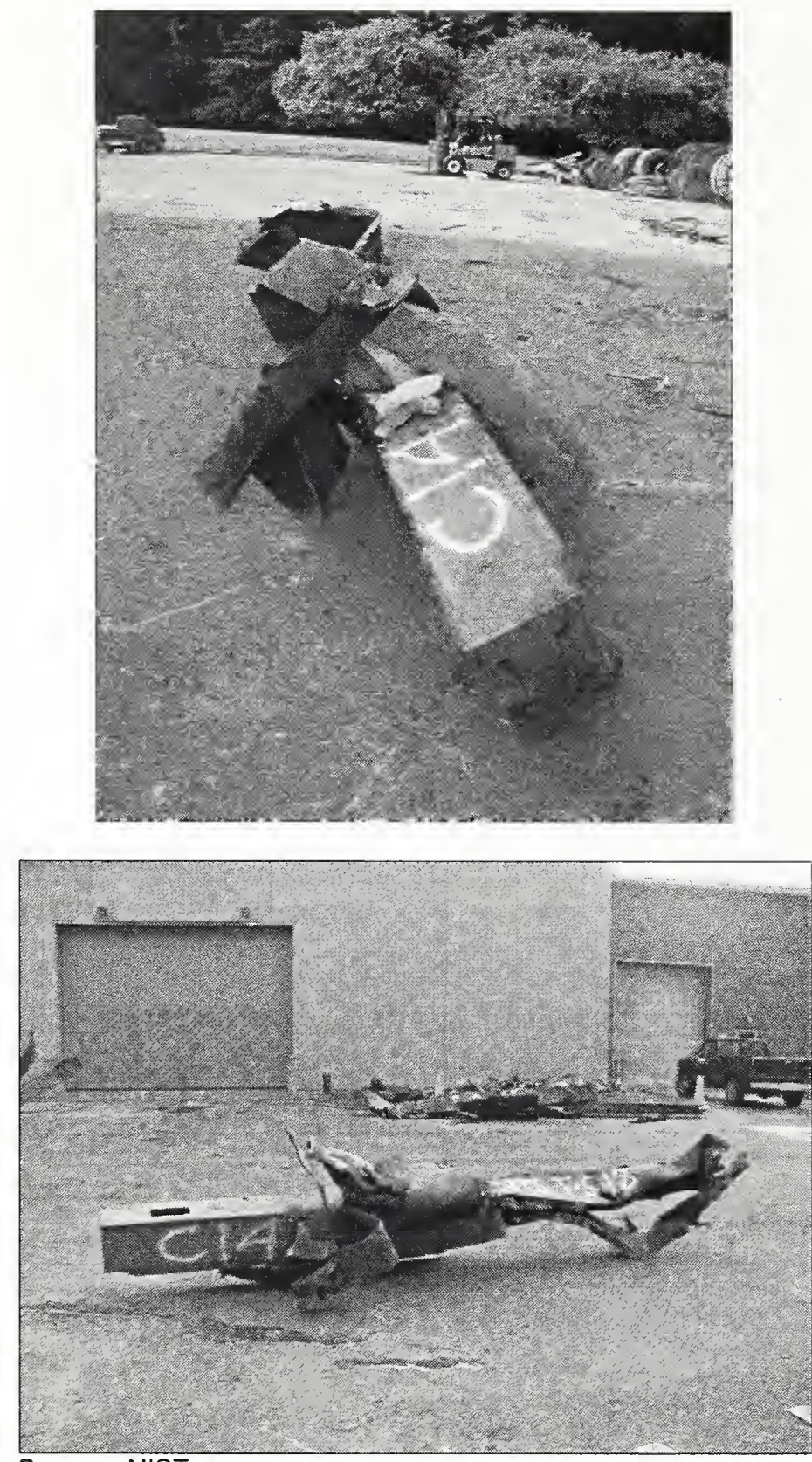

Source: NIST.

Figure 3-1. Characteristic "overall" view of the samples taken for each piece received.

Sample shown here is $\mathrm{C}-14$. 


\subsection{IDENTIFICATION OF WTC STRUCTURAL STEEL ELEMENTS}

Information from Leslie E. Robertson Associates (LERA) indicates that all structural stccl picces in WTC 1 and WTC 2 were uniquely identified by stampings (recessed letters and numbers) and/or paintcd stencils. ${ }^{3}$ NIST has been successful in finding these identification markings on many of the perimetcr panel sections, core columns, and other wide flange members. Of the 94 picces of perimeter pancl labeled in Table A-1, 90 distinct panels werc observed. (The other four picces of pcrimeter column had become separated from the main panel during salvage and were subsequently labclcd C-13a, C-16a. C. 28b, and K-16a.) At this time, of the 90 panels, 42 distinct exterior column pancls have been identificd and 1 partially identified. Tables 3-1 and 3-2 list these samples, respectively, with Fig. 3-2 showing the relative locations of the identified exterior panels within the top third of the buildings. Significantly more pieces were recovered from WTC 1 than WTC 2. Table 3-3 lists the 12 core columns in NIST's possession that have been positively identified through their stampings. An additional samplc, C-83, is also listed in this group. Though no markings were found on the piece, the shape and dimension of this sample are in conformance with the design drawings for core columns and it has a similar appearance to core column C-90. Additionally, there are 13 pieces of wide flange sections that have stampings and/or markings with a different code, Table 3-4. After review of these stampings by staff members from both the Port Authority of New York and New Jersey (PANYNJ) and LERA, no definite correlation between the markings and the contract document member labels was found. It was the opinion of LERA that the stampings/marks are shop marks that may or may not have been indicated in the original shop drawings. LERA believes that it does not have within its possession any shop drawings that are consistent with the members shown. Further, LERA studied the images to determine if the box members could be grouped into a member type typically found in the WTC buildings and was unsuccessful. Therefore, the as-built location of these pieces could not be determined nor could it be confirmed that they were part of the structural steel from the WTC towers.

The positive identification of the structural elements was made possible by deciphering the stampings and/or stencils found on them. During the fabrication process, the exterior panel sections were stamped at the bottom of the center column on the inside face. These stampings indicated the building, center column line number, and floors spanned by the columns. The core columns had stampings placed at the lower end of the component near the connector. The building was typically represented as "A" for WTC 1 and "B" for WTC 2. An example of a stamping found on an exterior column is shown in Fig. 3-3, where the stamping indicates that the piece was from WTC 2, with center column line number 206, spanning floors 83 through 86 . Core column rnaterial was found to have similar markings (Fig. 3-4). Other stampings have also been found on the flanges of the perimeter columns that indicated the column type (Fig. 3-5 and Table 3-5) as well as the specified minimum yield strength of the column. All of these stampings typically reside within $1 \mathrm{~m}$ from the bottom of the column.

3 Faschan, W. 2002. Leslie E. Robertson Associates, New York, NY, personal communication to F. Gayle. Project Leader, World Trade Center Investigation, National Institute of Standards and Technology, Gaithersburg, MD, May 21. 
Table 3-1. Identified exterior column panel pieces from WTC 1 and WTC 2.

\begin{tabular}{|c|c|c|c|c|c|c|}
\hline $\begin{array}{l}\text { NIST } \\
\text { Name }\end{array}$ & Type & Description & Bldg. & Column & Floors & $\begin{array}{l}\text { Derrick } \\
\text { Division }\end{array}$ \\
\hline ASCE 2 & $\mathrm{C}$ & 1 full column & WTC 2 & 330 & $40-43$ & NA \\
\hline B-1024 & $\mathrm{C}$ & Full panel & WTC 2 & 154 & $21-24$ & NA \\
\hline B-1043 & $\mathrm{C}$ & Full panel & WTC 2 & 406 & $40-43$ & NA \\
\hline B-1044 & $\mathrm{C}$ & Full panel & WTC 2 & 409 & $40-43$ & NA \\
\hline $\mathrm{C}-10$ & $\mathrm{C}$ & Full panel & WTC 1 & 451 & $85-88$ & $5 \mathrm{x}$ \\
\hline $\mathrm{C}-13$ & $\mathrm{CC}$ & Rectangular column with spandrel & WTC 2 & 200 & $90-92$ & 569 \\
\hline$C-13 a$ & $\mathrm{C}$ & Partial of single column & WTC 2 & 159 & $90-92$ & 569 \\
\hline $\mathrm{C}-14$ & $\mathrm{C}$ & 1 column, lower $1 / 3$ & WTC 2 & 300 & $85-87$ & 570 \\
\hline $\mathrm{C}-18$ & $\mathrm{C}$ & 3 columns, bottom $2 / 3$ & WTC 2 & 230 & $93-96$ & NA \\
\hline$C-22$ & $\mathrm{C}$ & 3 columns, lower $1 / 2$ & WTC 1 & 157 & $93-96$ & 69 \\
\hline $\mathrm{C}-24$ & $\mathrm{C}$ & 3 columns, upper $1 / 3$ & WTC 2 & 203 & $74-77$ & $\mathrm{NA}$ \\
\hline$C-25$ & $\mathrm{C}$ & 1 column, lower $1 / 2$ & WTC 1 & 206 & $89-92$ & 69 \\
\hline$C-40$ & $\mathrm{C}$ & 2 columns, lower $2 / 3$ & WTC 1 & 136 & 98-101 & $6 x$ \\
\hline $\mathrm{C}-46$ & $\mathrm{C}$ & Nearly full panel & WTC 2 & 157 & $68-71$ & 569 \\
\hline C-48 & $\mathrm{C}$ & Nearly 2 full columns & WTC 2 & 442 & $91-94$ & NA \\
\hline $\mathrm{C}-55$ & $\mathrm{C}$ & 1 column, lower $1 / 3$ & WTC 1 & 209 & $94-97$ & NA \\
\hline C-89 & $\mathrm{C}$ & 2 full columns & WTC 2 & 215 & $12-15$ & NA \\
\hline $\mathrm{C}-92$ & $\mathrm{C}$ & 1 column, lower $1 / 3$ & WTC 2 & 130 & $93-96$ & NA \\
\hline C-93 & $\mathrm{C}$ & 1 column, lower $1 / 3$ & WTC 1 & 339 & $99-102$ & NA \\
\hline $\mathrm{CC}$ & $\mathrm{C}$ & 2 full columns & WTC 1 & 124 & $70-73$ & NA \\
\hline $\mathrm{K}-1$ & $\mathrm{C}$ & 3 columns, lower $1 / 3$ & WTC 1 & 209 & $97-100$ & NA \\
\hline $\mathrm{K}-2$ & $\mathrm{C}$ & 1 column, lower $2 / 3$ & WTC 1 & 236 & $92-95$ & NA \\
\hline M-2 & $\mathrm{C}$ & Full panel & WTC 1 & 130 & $96-99$ & 63 \\
\hline $\mathrm{M}-10 \mathrm{a}$ & $\mathrm{C}$ & 3 columns, middle section $1 / 3$ & WTC 2 & 209 & $82-85$ & NA \\
\hline$M-10 b$ & $\mathrm{C}$ & 3 columns, lower $1 / 2$ & WTC 2 & 206 & $83-86$ & 569 \\
\hline M-20 & $\mathrm{C}$ & 2 columns, lower $1 / 3$ & WTC 1 & 121 & $99-102$ & 63 \\
\hline M-26 & $\mathrm{C}$ & Full panel & WTC 1 & 130 & $90-93$ & $6 \mathrm{x}$ \\
\hline M-27 & $\mathrm{C}$ & 2 columns, lower $3 / 4$ & WTC 1 & 130 & $93-96$ & 63 \\
\hline $\mathrm{M}-28$ & $\mathrm{C}$ & 3 columns, lower $1 / 4$ & WTC 2 & 345 & $98-101$ & NA \\
\hline M-30 & $\mathrm{C}$ & 2 columns, lower $1 / 3$ & WTC 1 & 133 & $94-97$ & 65 \\
\hline $\mathrm{N}-1$ & $\mathrm{C}$ & 2 full columns & WTC 1 & 218 & $82-85$ & NA \\
\hline $\mathrm{N}-7$ & $\mathrm{C}$ & Full panel & WTC 1 & 127 & $97-100$ & NA \\
\hline $\mathrm{N}-8$ & $\mathrm{C}$ & Full panel & WTC 1 & 142 & $97-100$ & 67 \\
\hline $\mathrm{N}-9$ & $\mathrm{C}$ & Nearly full panel & WTC 1 & 154 & $101-104$ & 69 \\
\hline$N-10$ & $\mathrm{C}$ & 2 columns, lower $2 / 3$ & WTC 1 & 115 & $89-92$ & $6 x$ \\
\hline $\mathrm{N}-12$ & $\mathrm{C}$ & 2 full columns & WTC 1 & 206 & $92-95$ & 69 \\
\hline $\mathrm{N}-13$ & $\mathrm{C}$ & 3 columns, lower $1 / 3$ & WTC 1 & 130 & $99-102$ & 63 \\
\hline
\end{tabular}


Table 3-1. Identified exterior column panel pieces from WTC 1 and WTC 2 (continued).

\begin{tabular}{|l|c|l|l|c|c|c|}
\hline $\begin{array}{c}\text { NIST } \\
\text { Name }\end{array}$ & Type & \multicolumn{1}{|c|}{ Description } & BIdg. & Column & Floors & $\begin{array}{c}\text { Derrick } \\
\text { Division }\end{array}$ \\
\hline N-99 & C & Nearly full panel & WTC 1 & 148 & $99-102$ & 67 \\
\hline N-101 & C & Full panel & WTC 1 & 133 & $100-103$ & 65 \\
\hline S-1 & C & 2 columns, lower 1/3 & WTC 1 & 433 & $79-82$ & 47 \\
\hline S-9 & C & Full panel & WTC 1 & 133 & $97-100$ & NA \\
\hline S-10 & C & 2 columns, lower 1/2 & WTC 1 & 224 & $92-95$ & NA \\
\hline S-14 & C & Full panel & WTC 2 & 218 & $91-94$ & 557 \\
\hline
\end{tabular}

Key: NA, information not available.

Note: " $\mathrm{x}$ " in the derrick division column indicates an unreadable number.

Table 3-2. Partially identified exterior column panel from WTC 1 or WTC 2.

\begin{tabular}{|c|c|c|c|c|c|}
\hline $\begin{array}{c}\text { NIST } \\
\text { Name }\end{array}$ & Type & Description & Bldg. & Column & Floors \\
\hline C-117 & C & 3 columns, lower 1/3 & NA & NA & $100-104$ \\
\hline
\end{tabular}

Key: NA, information not available.
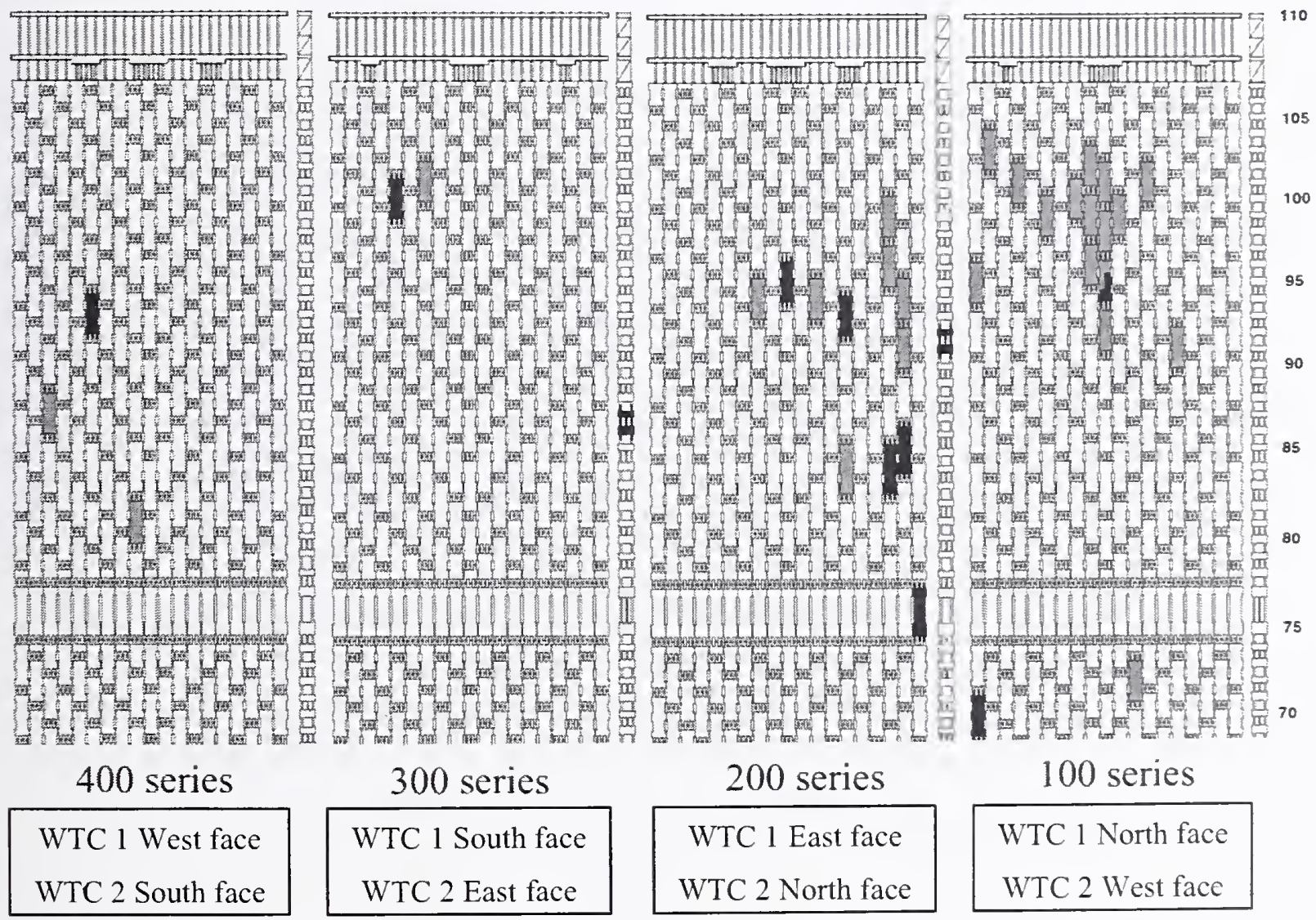

300 series

WTC 1 South face
WTC 2 East face

200 series

WTC 1 East face

WTC 2 North face
100 series

WTC 1 North face

WTC 2 West face

Note: WTC 1 panels are shown in green and WTC 2 panels are in blue.

Figure 3-2. Location of the exterior panels recovered from the top third of WTC 1 and WTC 2. 
Table 3-3. Identified pieces of core column material from WTC 1 and WTC 2.

\begin{tabular}{|l|c|l|l|c|c|c|c|}
\hline NIST Name & Type & \multicolumn{1}{|c|}{ Description } & Bldg. & Column & Floors & $\begin{array}{c}\text { Derrick } \\
\text { Division }\end{array}$ & $\begin{array}{c}F_{\mathbf{y}} \\
\text { (ksi) }\end{array}$ \\
\hline B-1011 & RB & Heavy rectangular column & WTC 1 & 508 & $51-54$ & 55 & 36 \\
\hline B-6152-1 & RB & Heavy rectangular column & WTC 1 & 803 & $15-18$ & 52 & 36 \\
\hline B-6152-2 & RB & Heavy rectangular column & WTC 1 & 504 & $33-36$ & 51 & 36 \\
\hline C-83 & RB & Heavy rectangular column & NA & NA & NA & NA & NA \\
\hline C-88a & RB & Heavy rectangular column & WTC 2 & 801 & $80-83$ & 550 & 42 \\
\hline C-88b & RB & Heavy rectangular column & WTC 2 & 801 & $77-80$ & 550 & 42 \\
\hline C-90 & RB & Heavy rectangular column & WTC 2 & 701 & $12-15$ & 549 & 36 \\
\hline C-30 or S-12 & W & Wide flange section & WTC 2 & 1008 & $104-106$ & NA & 36 \\
\hline C-65 or S-8 & W & Wide flange section & WTC 1 & 904 & $86-89$ & 52 & 36 \\
\hline C-71 & W & Wide flange section & WTC 1 & 904 & $77-80$ & NA & 36 \\
\hline C-80 & W & Wide flange section & WTC 1 & 603 & $92-95$ & 51 & 36 \\
\hline C-155 & W & Wide flange section & WTC 1 & 904 & $83-86$ & 52 & 36 \\
\hline HH or S-2 & W & Wide flange section & WTC 1 & 605 & $98-101$ & 53 & 42 \\
\hline
\end{tabular}

a. C-83 was not positively identified but due to similar size and shape was deemed a core column.

Key: NA, information not available.

Table 3-4. Other built-up box columns and wide flange sections from WTC 1 and WTC 2 with ambiguous stampings and/or markings.

\begin{tabular}{|c|c|c|c|}
\hline NIST Name & Type & Description & Markings \\
\hline $\mathrm{C}-79$ & RB & Thin rectangular column & $101 \mathrm{~A} 81-85-87-9252$ \\
\hline C-101 & $\mathrm{RB}$ & Thin rectangular column & $78 \mathrm{~A} \quad 10 \quad 27 \quad 50$ \\
\hline$C-154$ & RB & Thin rectangular column & 825: $107-108 \quad 52$ \\
\hline $\mathrm{C}-26$ & W & Three connected wide flange sections & $604 / 605 \quad 107 \quad 64 \quad 50$ \\
\hline$C-44$ & W & Wide flange section & $59 \quad \mathrm{~S} \quad 563$ \\
\hline $\mathrm{C}-45$ & W & Wide flange section & $16 \quad \mathrm{~S} 2 \quad 563 \quad F_{y} 50$ \\
\hline$C-60$ & W & Wide flange section & $193 \quad$ S1 69 \\
\hline C-61 & W & Wide flange section & S 69 \\
\hline$C-62$ & W & Wide flange section & $224(\mathrm{~S})<48>F_{y} 50$ \\
\hline $\mathrm{M}-17$ & W & Wide flange section & $163 \quad(9) \quad 62 \quad F_{y} 36$ \\
\hline M-23 & $\mathrm{W}$ & Wide flange section & F 2010 \\
\hline M-37 & W & Wide flange section & $130 \quad(8 x-92)<50>$ \\
\hline M-38 & $\mathrm{W}$ & Wide flange section & $F_{y} 42$ \\
\hline
\end{tabular}

Note: "x" indicates an unreadable number. 

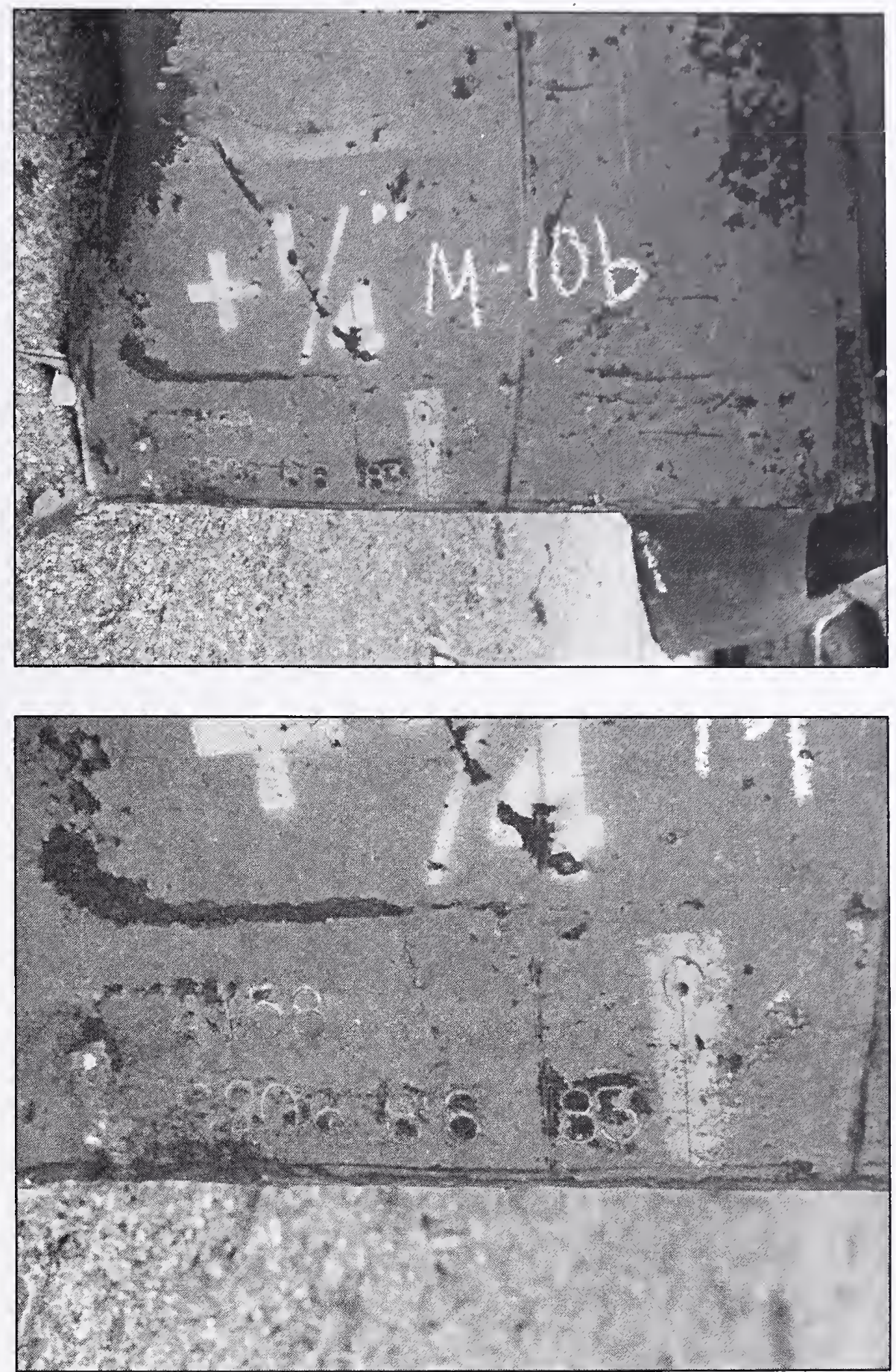

Source: NIST.

Figure 3-3. Example of stampings on the interior base of the middle column for each panel. 


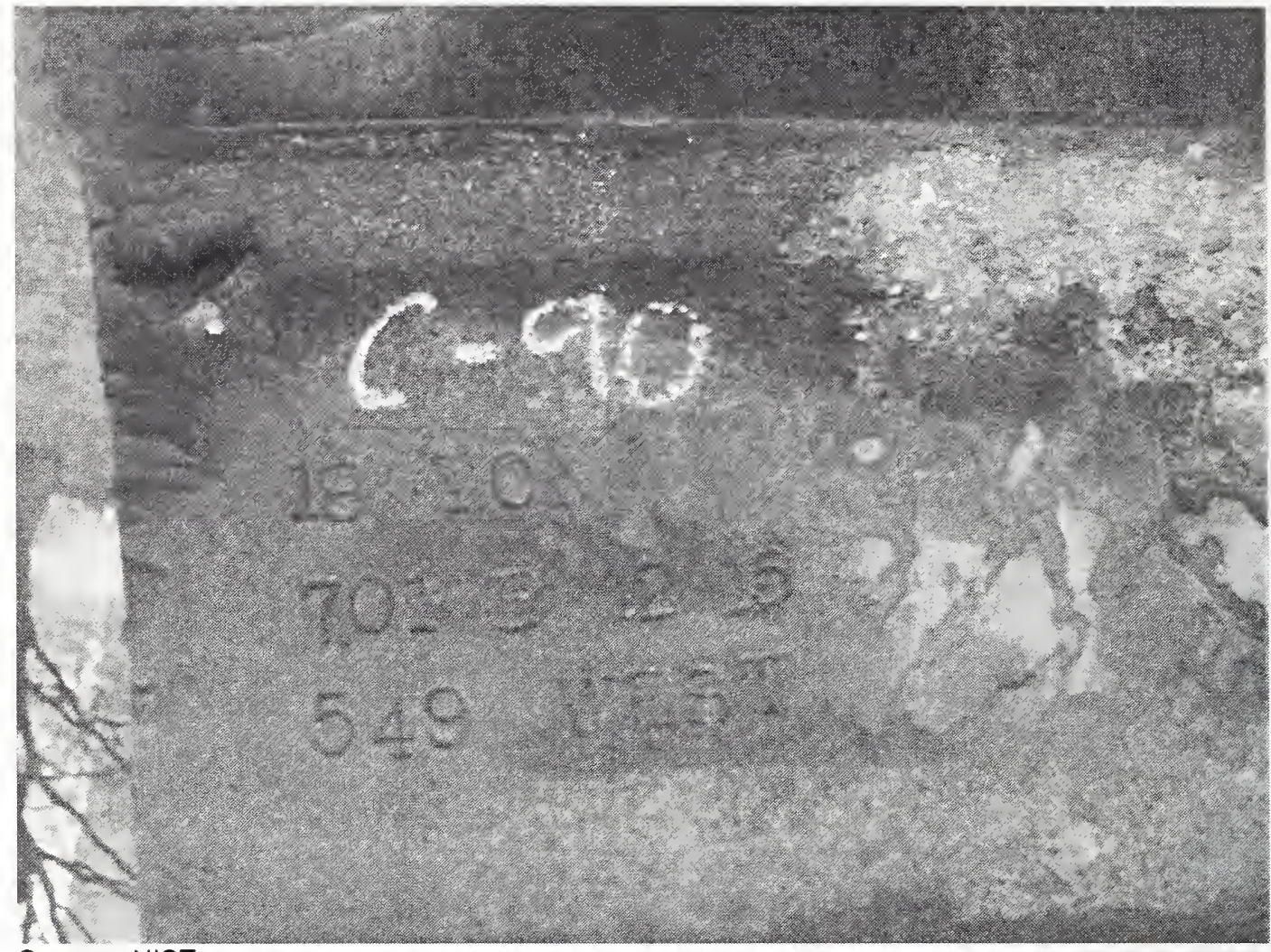

Source: NIST.

Figure 3-4. Example of stampings placed on one end of a core column. 
a)

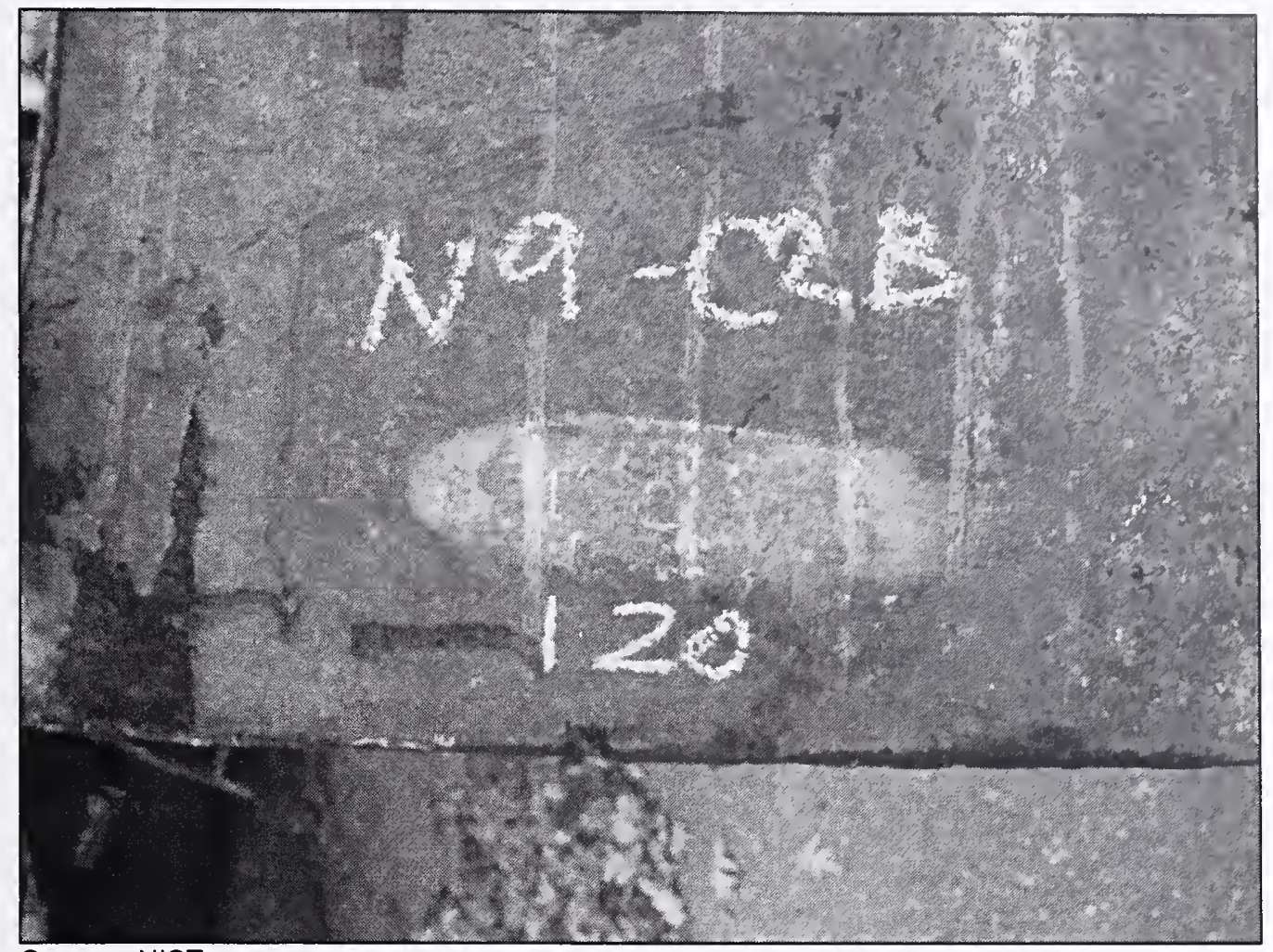

Source: NIST.

Plate 2

b)

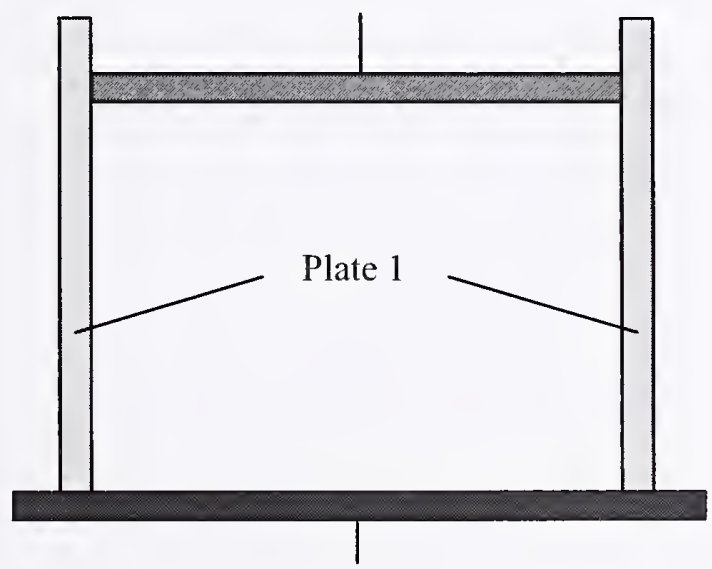

Plate 3

Figure 3-5. (a) Example of stamping placed on flange indicating the column type (120), and (b) schematic indicating the various plates corresponding to Table 3-5. 
Table 3-5. Examples of column types with corresponding plate gauges.

\begin{tabular}{|c|c|c|c|}
\hline Column Type & $\begin{array}{c}\text { Plate } 1 \\
\text { (in.) }\end{array}$ & $\begin{array}{c}\text { Plate } 2 \\
\text { (in.) }\end{array}$ & $\begin{array}{c}\text { Plate } 3 \\
\text { (in.) }\end{array}$ \\
\hline 120 & $1 / 4$ & $1 / 4$ & $1 / 4$ \\
\hline 121 & $5 / 16$ & $1 / 4$ & $1 / 4$ \\
\hline 122 & $3 / 8$ & $1 / 4$ & $1 / 4$ \\
\hline 123 & $7 / 16$ & $1 / 4$ & $1 / 4$ \\
\hline 124 & $1 / 2$ & $1 / 4$ & $1 / 4$ \\
\hline 125 & $9 / 16$ & $1 / 4$ & $1 / 4$ \\
\hline 126 & $5 / 8$ & $1 / 4$ & $1 / 4$ \\
\hline 128 & $3 / 4$ & $1 / 4$ & $1 / 4$ \\
\hline 129 & $13 / 16$ & $5 / 16$ & $5 / 16$ \\
\hline 133 & $11 / 16$ & $3 / 8$ & $3 / 8$ \\
\hline 149 & $21 / 16$ & $11 / 16$ & $11 / 16$ \\
\hline 150 & $21 / 8$ & $3 / 4$ & $3 / 4$ \\
\hline 152 & $21 / 4$ & $3 / 4$ & $3 / 4$ \\
\hline 334 & $11 / 8$ & $3 / 8$ & $3 / 8$ \\
\hline 335 & $13 / 16$ & $7 / 16$ & $7 / 16$ \\
\hline 520 & $1 / 4$ & $1 / 4$ & $1 / 4$ \\
\hline 522 & $3 / 8$ & $1 / 4$ & $1 / 4$ \\
\hline
\end{tabular}

Each of the structural elements was additionally stenciled in white or yellow lettering with similar building information. For the exterior panel sections, the stenciling was located on or near the lower spandrel on the interior face. Figure 3-6 (a) shows a typical stenciling found on a perimeter panel, indicating this piece was in WTC 2, with center column line number 300, spanning floors 85 through 87. For the core columns, both stenciling and handwritten codes have been observed on the recovered pieces. Figure 3-6 (b) shows one of these stencilings from a core column located in WTC 1.

Also seen in Fig. 3-6 (a) are two other indicators, 3T and $\langle 570\rangle$, found on the exterior panel sections. These markings are the estimated piece tonnage ( 1 ton equals approximately $907 \mathrm{~kg}$ ) and the erector's derrick division number, respectively. This information was also stamped on some of the core column pieces (see Fig. 3-4). The erector, Karl Koch Erecting Co., Inc., assigned derrick divisions 47 through 70 for WTC 1 and derrick divisions 547 through 570 for WTC 2. ${ }^{4}$ Each division was assigned to a specific area of the building and shared a crane with other nearby derrick divisions. Therefore, a single crane may have lifted pieces from derrick divisions 65, 67, and 69. Figure 3-7 shows the derrick division numbers that hoisted the specific columns for both buildings, according to the derrick numbers found on structural elements with positive identification (also shown in Tables 3-2 and 3-3).

${ }^{4}$ PONYA (Port of New York Authority). 1967. Communication to Steel Fabricators, Detailers, and Erectors, Shop drawing procedures and marking systems, May 1. 
a)

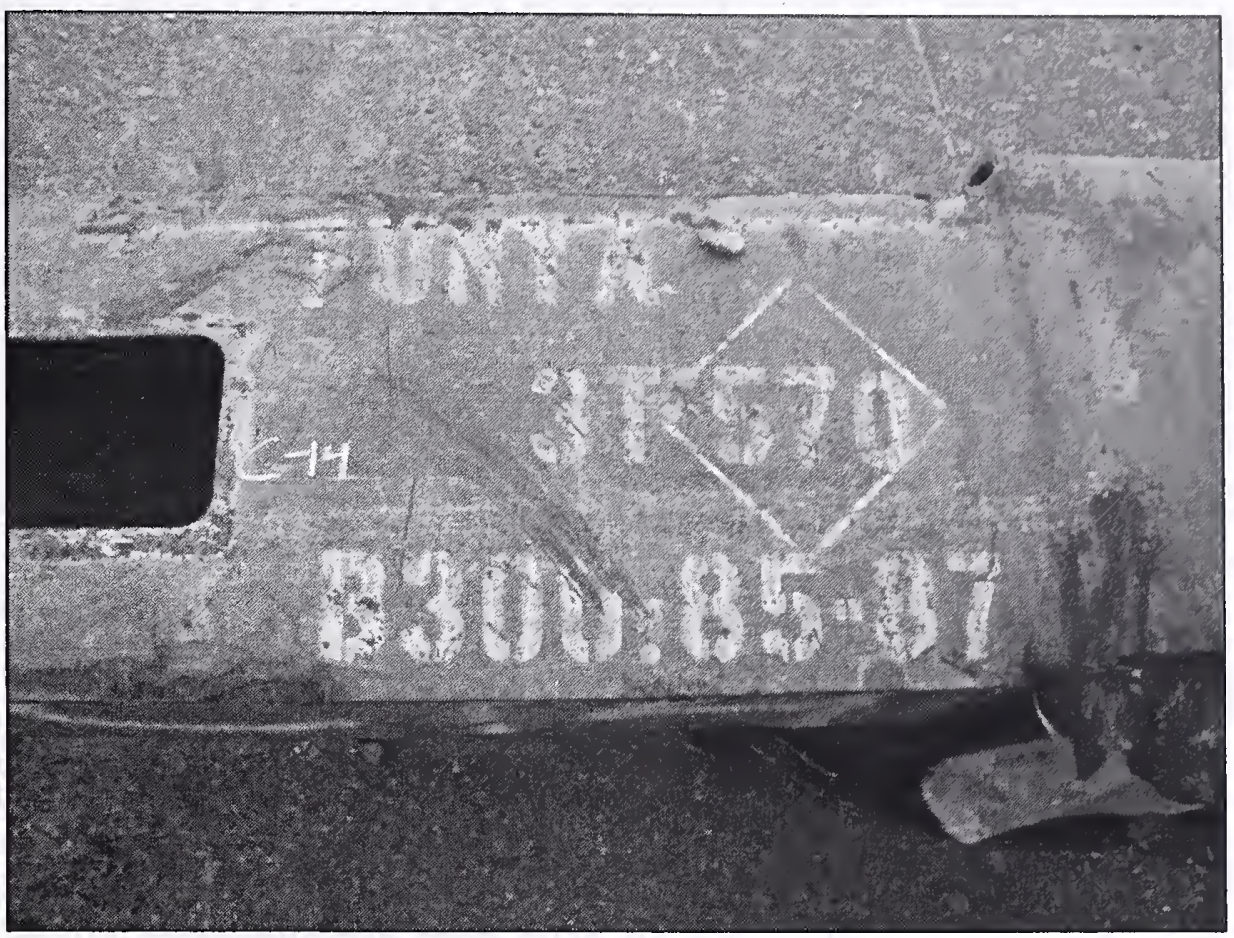

b)

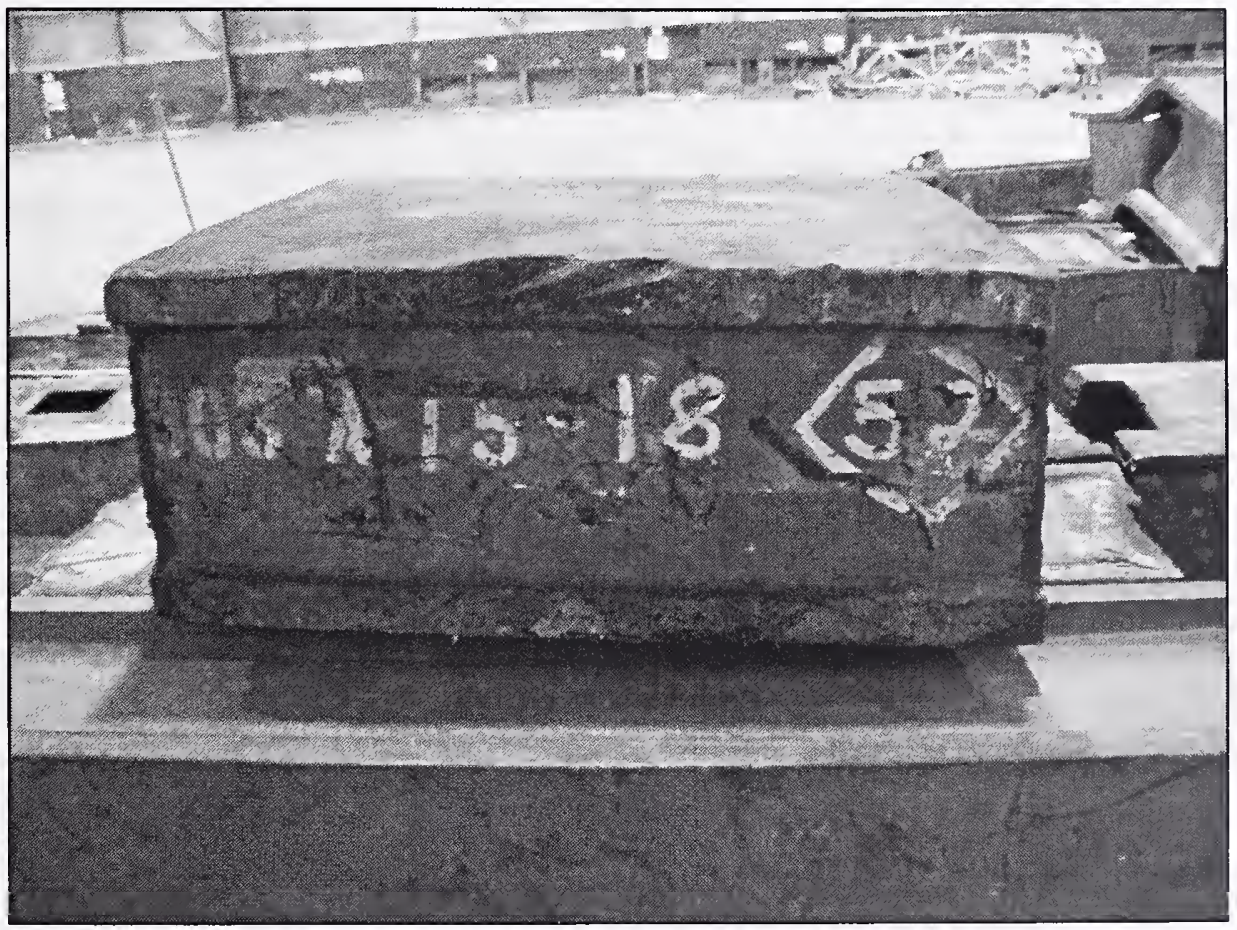

Source: NIST.

Figure 3-6. (a) Characteristic stenciling found on the lower portions of the exterior column panels for sample C-14. (b) Characteristic stenciling found on an interior core column for sample B-6152. 


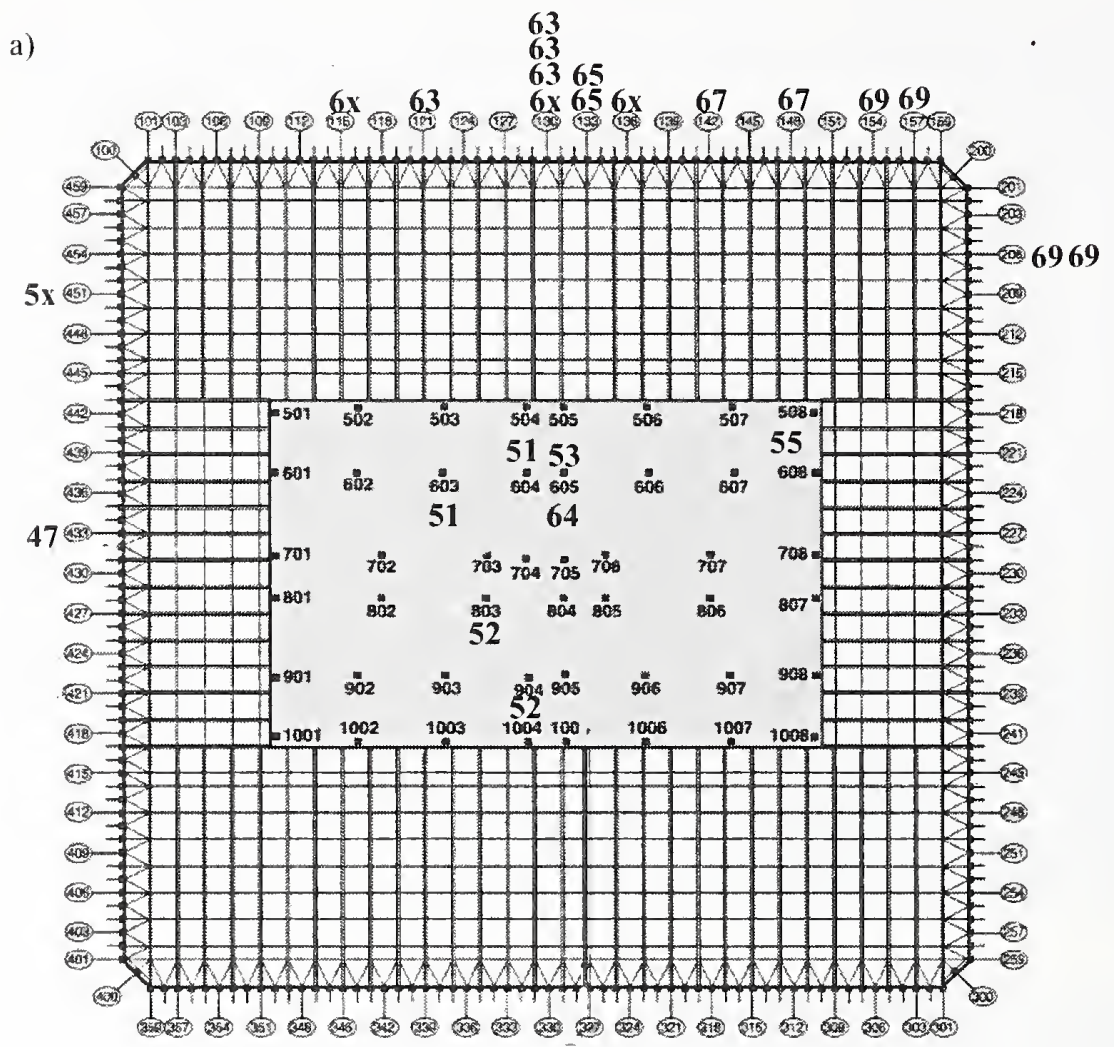

b)

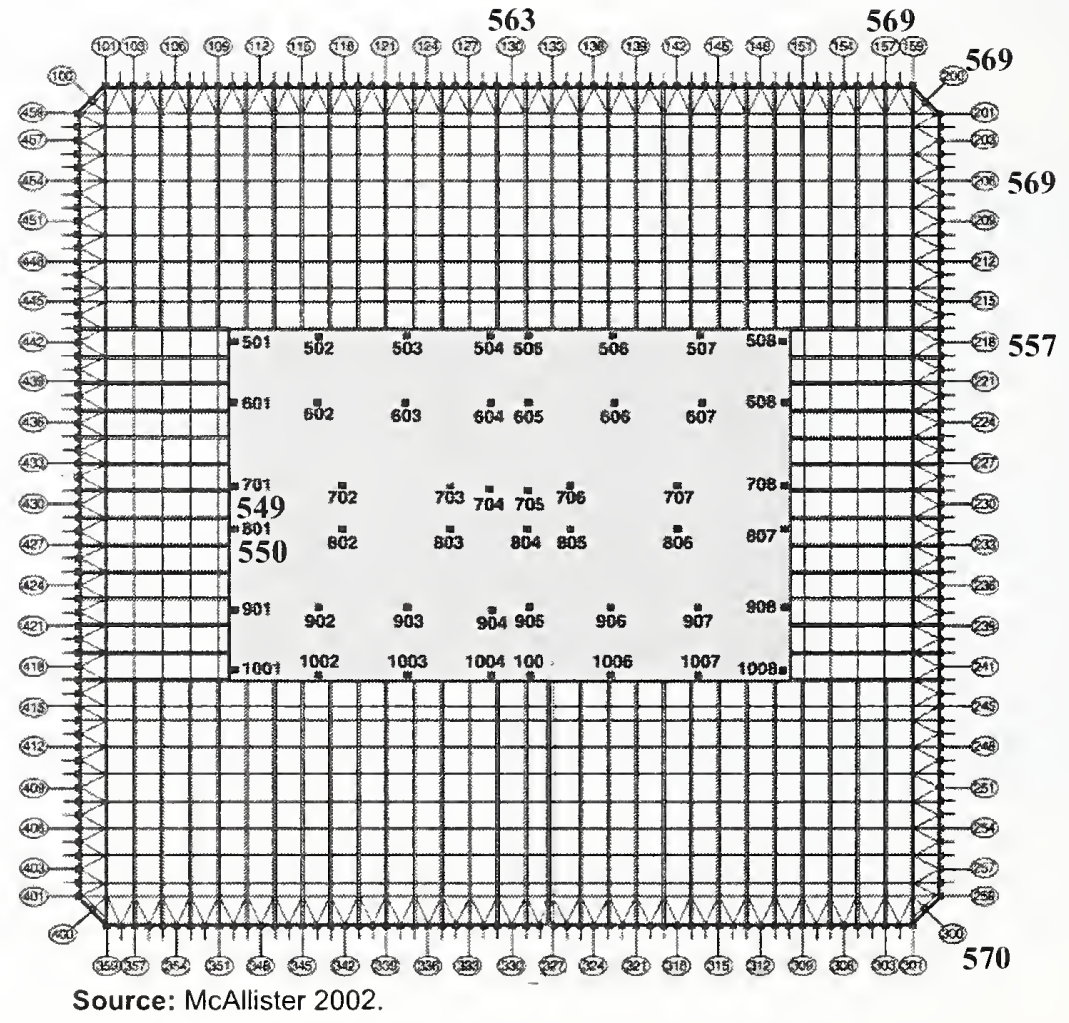

Figure 3-7. Schematic showing derrick divisions that hoisted the specific columns for (a) WTC 1 and (b) WTC 2. The " $x$ " signifies the information that was not readable. 
Of the 42 positively identified exterior panels, 25 had specific markings giving all the information needed (building, column, floors) to locate the structural elentent within the buildings from one or both codes (i.e., stampings or stencils). The flange stampings, which indicated the specified yicld strength and column type, were used to confirm the findings (Tables 3-6 and 3-7). The only deviation noted was that $100 \mathrm{ksi}$ steel was substituted for the $85 \mathrm{ksi}$ and $90 \mathrm{ksi}$ grades that were specificd. This ean be observed in Table 3-6 for samples B-1043, B-1044, C-10, and M-10b. This substitution is consistent with PANYNJ documents of the construction period, indicating that $100 \mathrm{ksi}$ stecl was used for all steel specificd as $85 \mathrm{ksi}$ or 90 ksi. (See NIST NCSTAR 1-3A, Contemporaneous Structural Steel Specifications.)

Seventeen other panels were positively identified using a combination of the stampings, including the specified minimum yield strength (Table 3-8) and column type (Table 3-9), the stenciled derrick division number (Table 3-8), or association to another panel, as follows:

- $\quad$ ASCE-2: No information was available signifying the panel identification as only the one outer column was recovered. The flange stampings indicated that the column was of the 356 type with $F_{y} 50 \mathrm{ksi}$ steel. The column had large floor truss seats that fit seat detail 4410 or 4424. Reviewing the building design drawings, seven panels meet the criterion that the leftmost column (when viewed from inside the building looking out) of the panel had the $356-$ 50 combination (Table 3-10). Of these, only one panel had the proper floor truss seat identifying the panel as B330: 40-43.

- $\quad$-10: The stampings indicated that the eenter column line number was 451 and the panel spanned floors 85 through 88 , but the building identification information was obscured by a weld bead. The building can be identified by a derrick division number in the 50 series, which corresponds to WTC 1 (Fig. 3-7). (Note that the flange stampings indicated that the steel used is $100 \mathrm{ksi}$, while the building design drawings indicated that $85 \mathrm{ksi}$ was specified. As mentioned above, substitution of the specified $85 \mathrm{ksi}$, as well as the $90 \mathrm{ksi}$ grades, by $100 \mathrm{ksi}$ steel was approved.)

- C-24: This piece was readily identifiable as a mechanical or service floor due to the nonuniform width of the columns. Unfortunately, only the upper portion of the panel was recovered, and thus no stampings were found. However, the end connections to these floors were welded in addition to the typical bolting. In doing so, the end plate and a small portion of the column from the panel above this piece remained after the collapse, and the stamping of "B $20377-78$ " identifying the panel above this sample was clearly visible.

- C-55: The stampings indicated that the center column line number was 209 and the panel spanned floors 94 through 97, however, no building information was observed. By reviewing the flange stampings (Table 3-8), the piece was determined to belong to WTC 1.

- C-92: Stenciling on the piece indicated that it was from WTC 2, floors 93 through 96. However, the center column line number was partially obscured, with $13 x$ visible. By reviewing the flange stampings (Tables 3-8 and 3-9), the piece center column line number was determined to be 130 . 
Table 3-6. Specified and observed minimum yield strengths for positively identified exterior column panels. ${ }^{\mathrm{a}}$

\begin{tabular}{|c|c|c|c|c|c|c|c|c|c|}
\hline \multirow{2}{*}{ NIST Name } & \multirow{2}{*}{ Bldg } & \multirow{2}{*}{ Column } & \multirow{2}{*}{ Floors } & \multicolumn{3}{|c|}{ Specified Minimum Yield (ksi) } & \multicolumn{3}{|c|}{ Stamping Observed } \\
\hline & & & & Column 1 & Column 2 & Column 3 & Column 1 & Column 2 & Column 3 \\
\hline$A \mathrm{SCE}-2$ & WTC 2 & 329 & $40-43$ & 50 & 50 & 50 & 50 & $N A_{L}$ & NA \\
\hline B-1024 & WTC 2 & 154 & $21-24$ & 50 & 50 & 50 & NA & 50 & NA \\
\hline B-1043 & WTC 2 & 406 & $40-43$ & 85 & 90 & 90 & 100 & 100 & 100 \\
\hline E-1044 & WTC 2 & 409 & $40-43$ & 85 & 80 & 85 & 100 & 80 & 100 \\
\hline $\mathrm{C}-10$ & WTC 1 & 451 & $85-88$ & 85 & 85 & 90 & 100 & 100 & 100 \\
\hline $\begin{array}{c}\mathrm{C}-13 \text { or } \mathrm{S}-11 \text { and } \\
\mathrm{C} 13 \mathrm{a} \text { or } \mathrm{S}-19\end{array}$ & WTC 2 & 200 & $90-92$ & 100 & 100 & 100 & 100 & NA & $\mathrm{NA}$ \\
\hline C-14 or $S-18$ & WTC 2 & 300 & $85-87$ & 100 & 100 & 100 & NA & $N A_{2}$ & $\mathrm{NA}$ \\
\hline C.18 & WTC 2 & 230 & $93-96$ & 55 & 55 & 55 & 55 & 55 & 55 \\
\hline C-22 & WTC 1 & 157 & $93-96$ & 80 & 75 & 80 & 80 & $N A$ & 80 \\
\hline$C-24$ & WTC 2 & 203 & $74-77$ & 100 & 100 & 100 & $\mathrm{NA}$ & NA & NA \\
\hline C. 25 & WTC 1 & 206 & $89-92$ & 80 & 80 & 80 & 80 & NA & $\mathrm{NA}$ \\
\hline C- 40 & WTC 1 & 136 & $98-101$ & 60 & 60 & 55 & NA & 60 & 55 \\
\hline C- 46 & WTC 2 & 157 & $68-71$ & 80 & 70 & 65 & 80 & $N A$ & 65 \\
\hline C-48 or S- 5 & WTC 2 & 442 & $91-94$ & 65 & 65 & 65 & $\mathrm{NA}$ & 65 & $\mathrm{NA}$ \\
\hline C- 55 & WTC 1 & 209 & $94-97$ & 70 & 70 & 70 & $N A$ & 70 & NA \\
\hline C- 89 & WTC 2 & 215 & $12-15$ & 50 & 50 & 55 & $\mathrm{NA}$ & $N A$ & $N A$ \\
\hline C-92. & WTC 2 & 130 & $93-96$ & 60 & 60 & 60 & 60 & NA & NA \\
\hline$C-93$ & WTC 1 & 339 & $99-102$ & 60 & 60 & 60 & $N A_{-}$ & 60 & $N A$ \\
\hline $\mathrm{CC}$ & WTC 1 & 124 & $70-73$ & 50 & 50 & 50 & NA & 50 & 50 \\
\hline $\mathrm{K}-1$ or $\mathrm{K}-13$ & WTC 1 & 209 & $97-100$ & 60 & 60 & 60 & 60 & 60 & 60 \\
\hline$K-2$ or $K-40$ & WTC 1 & 236 & $92-95$ & 65 & 65 & 65 & NA & 65 & $N A$ \\
\hline$M-2$ & WTC 1 & 130 & $96-99$ & 55 & 55 & 55 & 55 & 55 & 55 \\
\hline M-10a & WTC 2 & 209 & 82.85 & 85 & 85 & 85 & NA & $N A$ & $N A$ \\
\hline$M-10 b$ & WTC 2 & 206 & $83-86$ & 85 & 85 & 85 & 100 & 100 & $\mathrm{NA}$ \\
\hline $\mathrm{M}-20$ & WTC 1 & 121 & $99-102$ & 55 & 55 & 55 & $\mathrm{NA}$ & 55 & 55 \\
\hline $\mathrm{M}-26$ & WTC 1 & 130 & $90-93$ & 50 & 55 & 50 & NA & 55 & 50 \\
\hline $\mathrm{M}-27$ & WTC 1 & 130 & 93.96 & 50 & 55 & 55. & 50 & 55 & NA \\
\hline $\mathrm{M}-28$ & WTC 2 & 345 & $98-101$ & 70 & 70 & 70 & NA & NA & $\mathrm{NA}$ \\
\hline $\mathrm{M}-30$ & WTC 1 & 133 & $94-97$ & 55 & 55 & 55 & NA & 55 & 55 \\
\hline$N-1$ & WTC 1 & 218 & $82-85$ & 70 & 75 & 75 & 70 & 75 & $N A$ \\
\hline $\mathrm{N}-7$ or $\mathrm{M}-3$ & WTC 1 & 127 & $97-100$ & 55 & 55 & 60 & 55 & 55 & 60 \\
\hline $\mathrm{N}-8$ or $\mathrm{M}-7$ & WTC 1 & 142 & $97-100$ & 60 & 60 & 60 & $N A$ & 60 & NA \\
\hline $\mathrm{N}-9$ or $\mathrm{M}-8$ & WTC 1 & 154 & $101-104$ & 55 & 55 & 55 & 55 & 55 & $N A_{L}$ \\
\hline $\mathrm{N}-10$ or $\mathrm{M}-15$ & WTC 1 & 115 & $89-92$ & 55 & 55 & 55 & NA & 55 & 55 \\
\hline $\mathrm{N}-12$ or $\mathrm{M}-13$ & WTC 1 & 206 & $92-95$ & 75 & 75 & 75 & NA & 75 & 75 \\
\hline $\mathrm{N}-13$ or $\mathrm{M}-14$ & WTC 1 & 130 & $99-102$ & 55 & 55 & 55 & $N A_{-}$ & NA & $\mathrm{NA}$ \\
\hline $\mathrm{N}-99$ or $\mathrm{M}-16$ & WTC 1 & 148 & $99-102$ & 65 & 65 & 65 & 65 & 65 & $\mathrm{NA}$ \\
\hline $\mathrm{N}-101$ or $\mathrm{M}-21$ & WTC 1 & 133. & $100-103$ & 55 & 55 & 55 & 55 & 55 & 55 \\
\hline $\mathrm{S}-1$ or $\mathrm{EE}$ & WTC 1 & 433 & $79-82$ & 70 & 70 & 70 & $\mathrm{NA}$ & 70 & 70 \\
\hline S-9 or C- 63 & WTC 1 & 133 & $97-100$ & 55 & 55 & 55 & 55 & 55 & 55 \\
\hline $\mathrm{S}-10$ or $\mathrm{C}-17$ & WTC 1 & 224 & $92-95$ & 70 & 70 & 70 & 70 & 70 & $\mathrm{NA}$ \\
\hline $\mathrm{S}-14$ or $\mathrm{C}-20$ & WTC 2 & 218 & $91-94$ & 65 & 65 & 70 & 65 & 65 & 70 \\
\hline
\end{tabular}

a. Columns 1,2, and 3 are viewed left to right as viewed from the inside of the building.

Key: NA, information not available. 
Table 3-7. Specified and observed column types for positively identified exterior column panels. ${ }^{\mathrm{a}}$

\begin{tabular}{|c|c|c|c|c|c|c|c|c|c|}
\hline \multirow{2}{*}{ NIST Name } & \multirow{2}{*}{ Bldg } & \multirow{2}{*}{ Column } & \multirow{2}{*}{ Floors } & \multicolumn{3}{|c|}{ Specified Column Type } & \multicolumn{3}{|c|}{ Stamping Observed } \\
\hline & & & & Column 1 & Column 2 & Column 3 & Column 1 & Columur 2 & Columa 3 \\
\hline$\overline{A S C E}-2$ & WTC2 & 329 & $40-43$ & 356 & 356 & 356 & 356 & $H A_{2}$ & NA \\
\hline B-1024 & WTC 2 & 154 & $21-24$ & 149 & 150 & 152 & 149 & 150 & 152 \\
\hline B-1043 & WTC 2 & 406 & $40-43$ & 335 & 334 & 334 & 335 & 334 & 334 \\
\hline B-1044 & WTC 2 & 409 & $40-43$ & 335 & 335 & 335 & 335 & 335 & 335 \\
\hline$C-10$ & WTC 1 & 451 & $85-88$ & 120 & 120 & 120 & 120 & 120 & 120 \\
\hline $\begin{array}{c}\mathrm{C}-13 \text { or } \mathrm{S}-11 \text { and } \\
\mathrm{C} 13 \mathrm{a} \text { or } \mathrm{S}-19\end{array}$ & WTC 2 & 200 & $90-92$ & 120 & 520 & 120 & 120 & $1 H A$ & $\mathrm{NA}$ \\
\hline C-14 or S-18 & WTC 2 & 300 & $85-87$ & 122 & 522 & 120 & $N A$ & $1 \mathrm{H} A$ & WA \\
\hline C-18 & WTC 2 & 230 & $93-96$ & 120 & 120 & 120 & 120 & 120 & 120 \\
\hline$C-22$ & WTC 1 & 157 & $93-96$ & 120 & 120 & 120 & 120 & NA & 120 \\
\hline C- 24 & WTC 2 & 203 & $74-77$ & 325 & 325 & 325 & \multicolumn{3}{|c|}{ Bottoms missing } \\
\hline C-25 & WTC 1 & 206 & $89-92$ & 120 & 120 & 120 & 120 & NA & NA \\
\hline$C-40$ & WTC 1 & 136 & $98-101$ & 121 & 121 & 121 & NA & 121 & 121 \\
\hline$C-46$ & WTC 2 & 157 & $68-71$ & 126 & 128 & 129 & 126 & NA & 129 \\
\hline C- 48 or S-5 & WTC 2 & 442 & $91-94$ & 120 & 120 & 120 & $\mathrm{NA}$ & 120 & N. $A_{2}$ \\
\hline C- 55 & WTC 1 & 209 & $94-97$ & 120 & 120 & 120 & NA & 120 & $\mathrm{NA}$ \\
\hline C- 89 & WTC 2 & 215 & $12-15$ & 147 & 145 & 143 & $\mathrm{NA}$ & $1 \mathrm{~A} \Delta$ & N $A_{2}$ \\
\hline C- 92 & WTC 2 & 130 & $93-96$ & 124 & 123 & 123 & 124 & $\mathrm{NA}$ & NA \\
\hline C-93 & WTC 1 & 339 & $99-102$ & 121 & 121 & 121 & $N A_{A}$ & 121 & $\mathrm{~N} \mathrm{~A}_{2}$ \\
\hline $\mathrm{CC}$ & WTC 1 & 124 & $70-73$ & 133 & 133 & 133 & $\mathrm{~N} A$ & 133 & 133 \\
\hline $\mathrm{K}-1$ or $\mathrm{K}-13$ & WTC 1 & 209 & $97-100$ & 120 & 120 & 120 & 120 & 120 & 120 \\
\hline$K-2$ or $K-40$ & WTC 1 & 236 & $92-95$ & 120 & 120 & 120 & $N A$ & 120 & $\mathrm{NA}$ \\
\hline $\mathrm{M}-2$ & WTC 1 & 130 & $96-99$ & 122 & 122 & 122 & 122 & 122 & 122 \\
\hline$M-10 a$ & WTC 2 & 209 & $82-85$ & 120 & 120 & 120 & $N A$ & $N A$ & NA \\
\hline$M-10 b$ & WTC 2 & 206 & $83-86$ & 120 & 120 & 120 & 120 & 120 & $N A_{2}$ \\
\hline M-20 & WTC 1 & 121 & $99-102$ & 120 & 120 & 120 & $N A$ & 120 & 120 \\
\hline M-26 & WTC 1 & 130 & $90-93$ & 125 & 125 & 125 & $\mathrm{NA}$ & 125 & 125 \\
\hline M-27 & WTC 1 & 130 & $93-96$ & 124 & 123 & 123 & 124 & 123 & $N A$ \\
\hline M-28 & WTC 2 & 345 & $98-101$ & 120 & 120 & 120 & $N A$ & $N A$ & $N A$ \\
\hline$M-30$ & WTC 1 & 133 & $94-97$ & 123 & 123 & 123 & NA & 123 & 123 \\
\hline $\mathrm{N}-1$ & WTC 1 & 218 & $82-85$ & 123 & 123 & 123 & 123 & 123 & $N A_{-}$ \\
\hline $\mathrm{N}-7$ or $\mathrm{M}-3$ & WTC 1 & 127 & $97-100$ & 121 & 121 & 121 & 121 & 121 & 121 \\
\hline $\mathrm{N}-8$ or $\mathrm{M}-7$ & WTC 1 & 142 & $97-100$ & 121 & 121 & 121 & $N A$ & 121 & NA \\
\hline $\mathrm{N}-9$ or $\mathrm{M}-8$ & WTC 1 & 154 & 101-104 & 120 & 120 & 120 & 120 & 120 & $\mathrm{NA}$ \\
\hline $\mathrm{N}-10$ or $\mathrm{M}-15$ & WTC 1 & 115 & $89-92$ & 125 & 125 & 125 & $N A_{2}$ & 125 & 125 \\
\hline $\mathrm{N}-12$ or $\mathrm{M}-13$ & WTC 1 & 206 & $92-95$ & 120 & 120 & 120 & NA & 120 & 120 \\
\hline $\mathrm{N}-13$ or $\mathrm{M}-14$ & WTC 1 & 130 & $99-102$ & 121 & 121 & 120 & $\mathrm{NA}$ & $N A$ & $\mathrm{NA}$ \\
\hline $\mathrm{N}-99$ or $\mathrm{M}-16$ & WTC 1 & 148 & $99-102$ & 120 & 120 & 120 & 120 & 120 & $\mathrm{NA}$ \\
\hline $\mathrm{N}-101$ or $\mathrm{M}-21$ & WTC 1 & 133 & $100-103$ & 120 & 120 & 120 & 120 & 120 & 120 \\
\hline S-1 or EE & WTC 1 & 433 & $79-82$ & 123 & 123 & 123 & NA & 123 & 123 \\
\hline$S-9$ or $C-63$ & WTC 1 & 133 & $97-100$ & 122 & 122 & 122 & 122 & 122 & 122 \\
\hline S- 10 or $C-17$ & WTC 1 & 224 & $92-95$ & 120 & 120 & 120 & 120 & 120 & NA \\
\hline S- 14 or C- 20 & WTC 2 & 218 & $91-94$ & 120 & 120 & 120 & 120 & 120 & 120 \\
\hline
\end{tabular}

a. Columns 1,2 , and 3 are viewed left to right as viewed from the inside of the building.

Key: NA, information not available. 


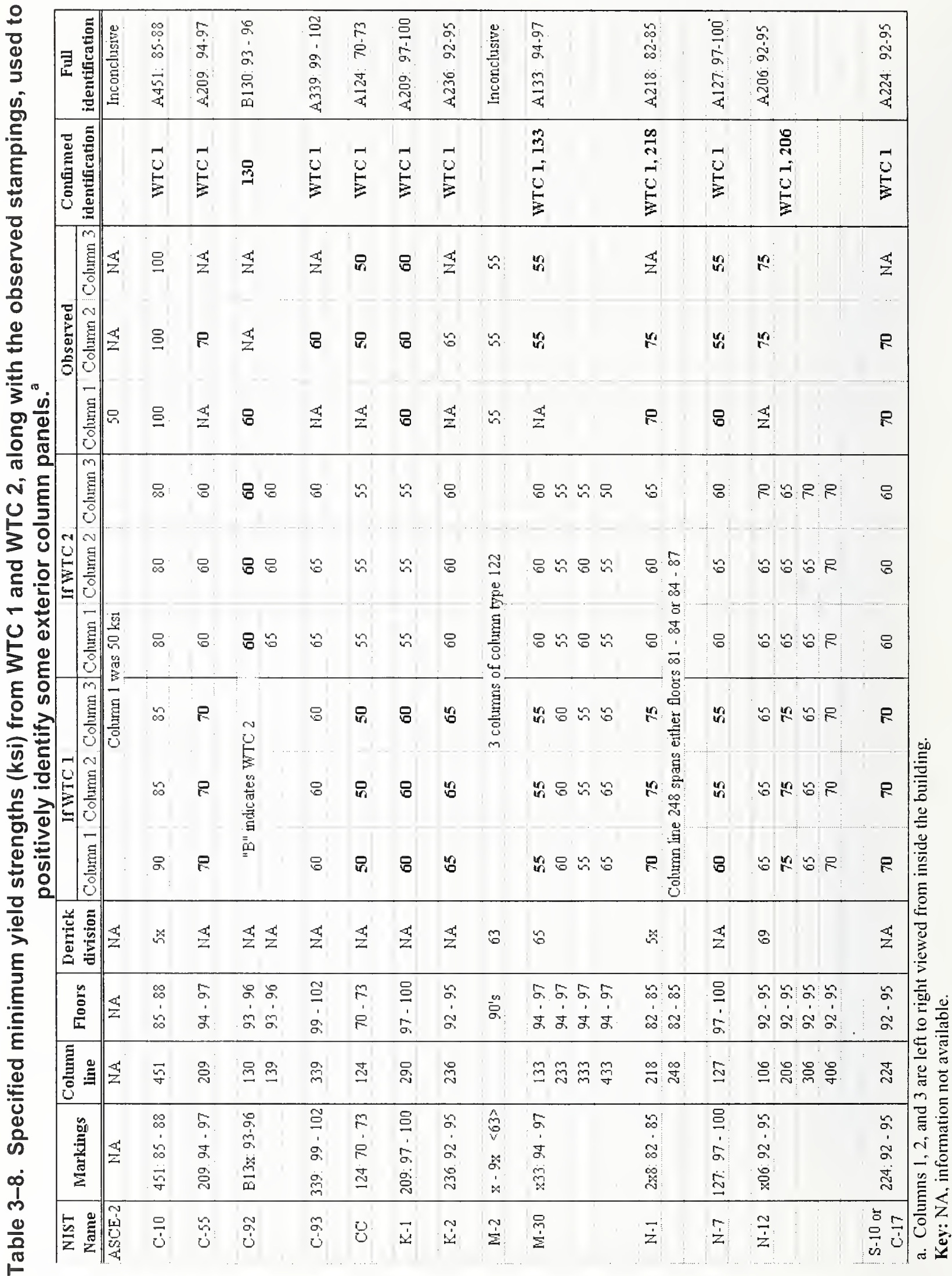




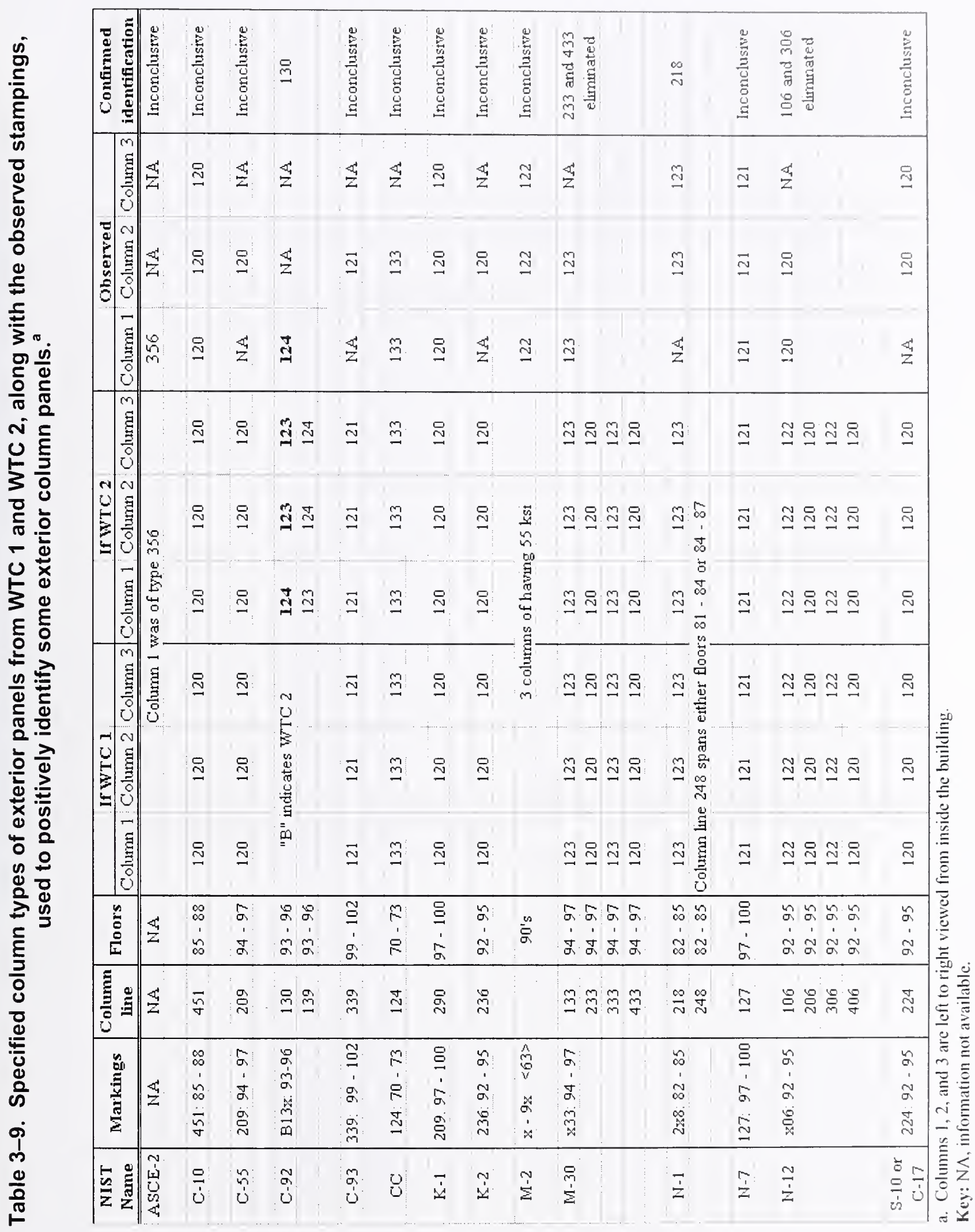




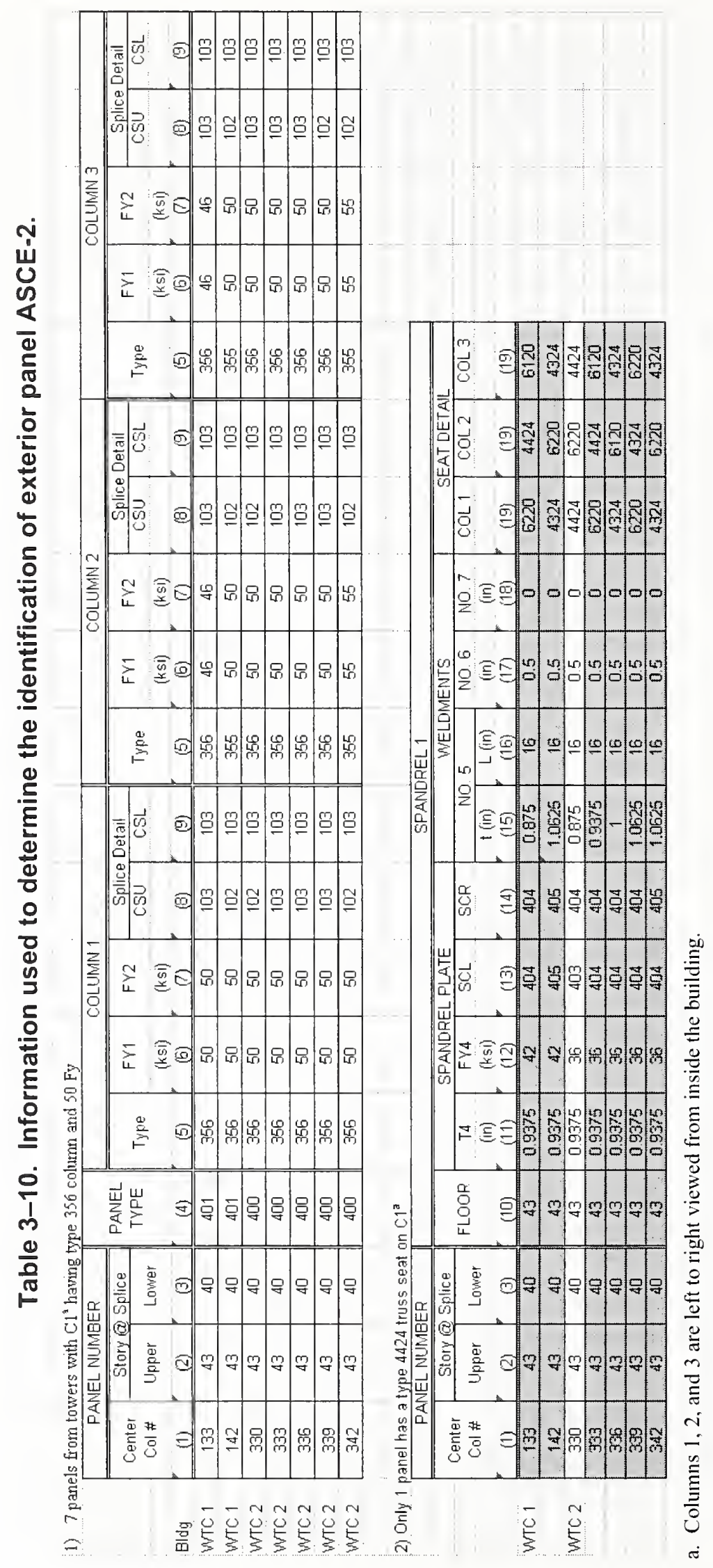


- $\quad$-93: The stampings indicated that the center column line number was 339 and the panel spanned floors 99 through 102; however, no building information was observed. By reviewing the flange stampings (Table 3-8), the piece was determined to belong to WTC 1.

- $\quad$ CC: The stampings indicated that the center column line number was 124 and the panel spanned floors 70 through 73; howevcr, no building information was observed. By reviewing the flange stampings (Table 3-8), the piece was determined to belong to WTC 1 .

- K-1: The stampings indicated that the center column line number was 209 and the panel spanned floors 97 through 100; however, no building information was observed. By reviewing the flange stampings (Table 3-8), the piece was determined to belong to WTC 1 .

- $\quad$ K-2: The stampings indicated that the center column line number was 236 and the panel spanned floors 92 through 95; however, no building information was observed. By reviewing the flange stampings (Table 3-8), the piece was determined to belong to WTC 1.

- M-2: No information was available from the stampings at the base of the middle column, and very little information was recovered from the stenciling on the spandrel. A derrick division number of $<63>$ was observed, placing the element in WTC 1 (Table 3-8). The only other information was -9 , indicating that some portion of the panel was located in the 90 s-floor-level range. The flange stampings from the recovered picce specified that all three columns were of the 122 type, with $F_{y} 55 \mathrm{ksi}$ steel. In addition, columns 1 and 3 had floor truss seats, while column 2 had gusset plates for the diagonal bracing straps. Reviewing the building design drawings, it was found that five pancls meet the 122 column type, with $55 \mathrm{ksi}$ steel in the 90s range (Table 3-11). Of these, only two panels had columns 1 and 3 with floor truss seats (130: 96 through 99 and 330: 96 through 99). As shown in Fig. 3-7, the derrick division of $<63>$ identifies the panel as 130: 96 through 99 .

- M-10a: The sample was identified solely by association to another panel (bolted spandrel connection). The sample M-10 retrieved by SEAoNY was actually composed of pieces from two different exterior column panels (Fig. 3-8). Therefore, with the positive identification of $\mathrm{M}-10 \mathrm{~b}$ via the stampings and stencils, M-10a's connection to it allowed its identification as WTC 2,209: 82 through 85.

- M-28: The stampings indicated that the center column line number was 345 and the panel was located in WTC 2. However, the markings of the floors spanned were partially obscured; $9 \mathrm{x}-1 \mathrm{xx}$. By reviewing the building design drawings, the only panel that could fit spanned floors 98 through 101 .

- $\quad$ M-30: The stampings found were $x 33$ 94-97, where the " $x$ " signifies missing information due to a weld bead running across this area. Thus, the building and exact center column line numbers were unknown. However, a derrick division number of $\langle 65\rangle$ was visible on the interior spandrel. From this information, as well as the specified minimum yield strength (Table 3-8) and column type (Table 3-9), M-30 was determined to belong to WTC 1, with a center column line number of 133 . 

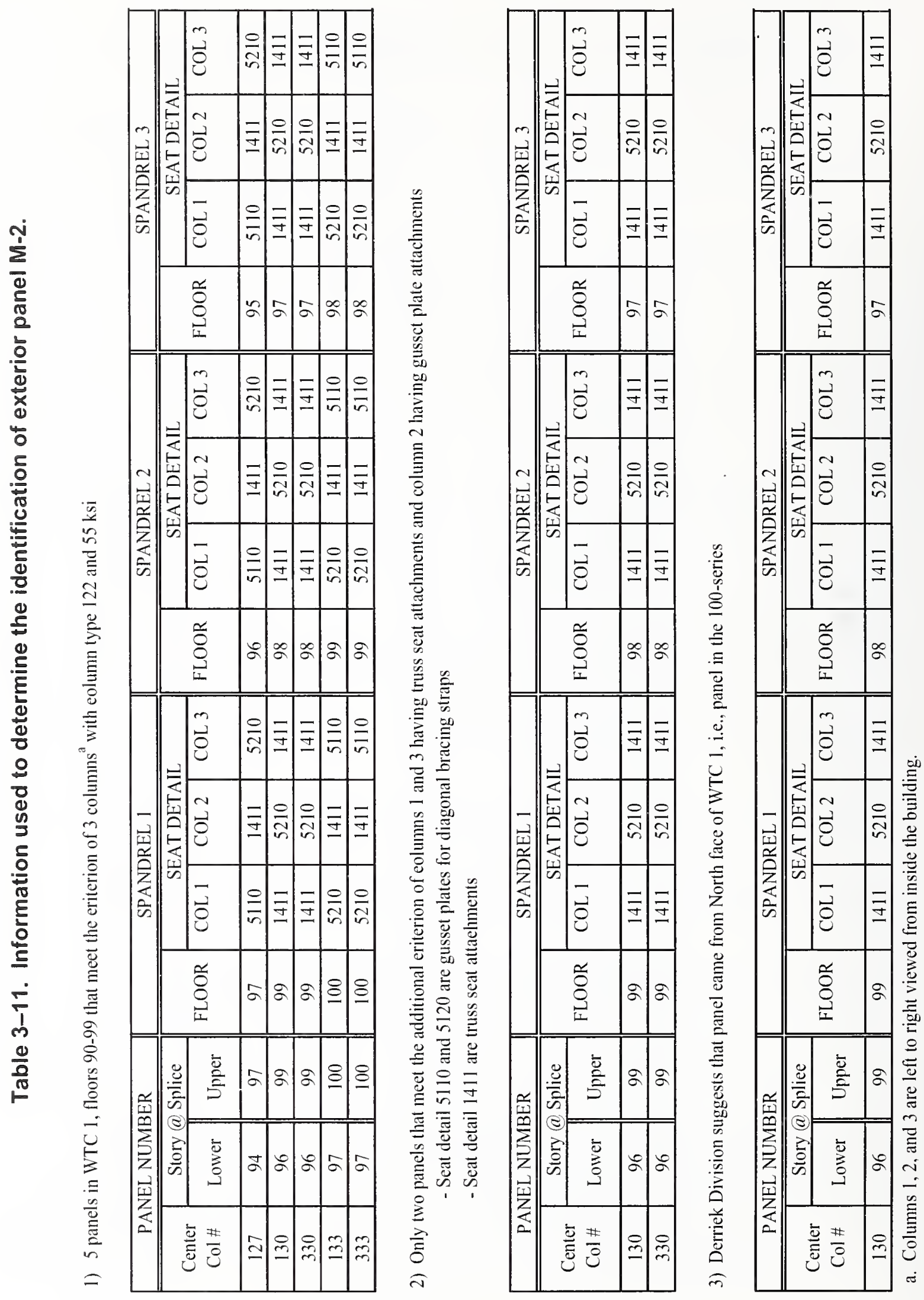


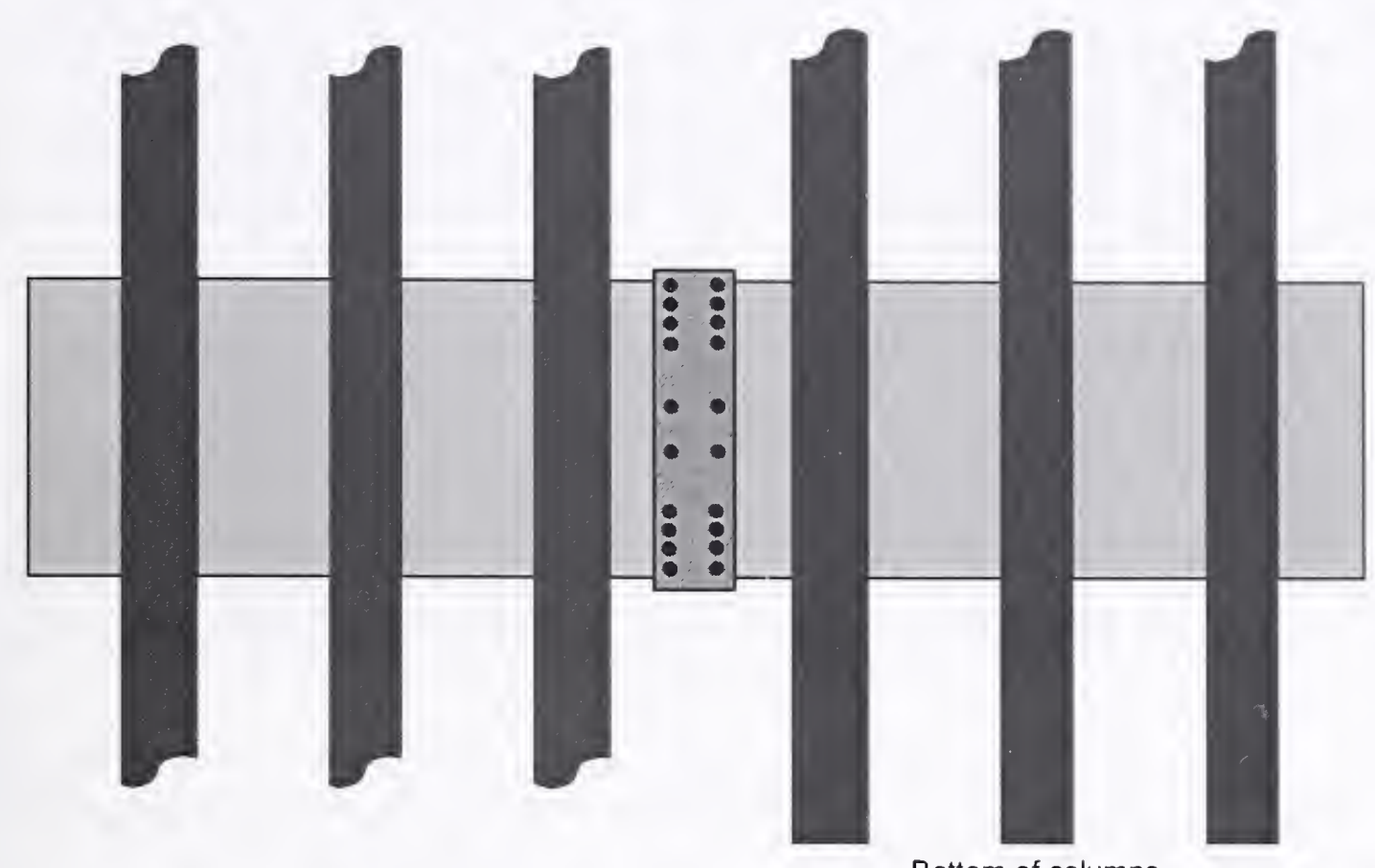

$M-10 a$

$M-10 b$

Figure 3-8. Schematic showing the sample $M-10$ as two separate exterior column panels, $M-10 a$ and $M-10 b$.

- $\mathbf{N}-\mathbf{1}$ : The stampings indicated that the columns spanned floors 82 through 85 ; however, no building information was observed and a weld bead ran through the middle of the center column line number yielding only " $2 \times 8$." By reviewing the building plans, only column line 218 spanned the floors specified and the flange stampings (Tables 3-8 and 3-9) indicated that the piece belonged to WTC 1 .

- $\quad \underline{\mathbf{N}-7}$ : The stampings indicated that the center column line number was 127 and spanned floors 97 through 100 , however, no building information was observed. By reviewing the flange stampings (Table 3-8), the piece belonged to WTC 1.

- N-12: The stampings found were $\mathrm{x} 06$ 92-95 where the "x" signifies missing information due to a weld bead running across this area. Thus, the building and exact center column line numbers were unknown. However, a derrick division number of $\langle 69\rangle$ was visible on the interior spandrel. From this information, as well as the specified minimum yield strength (Table 3-8) and column type (Table 3-9), it was determined that N-12 belonged to WTC 1, with a center column line number of 206.

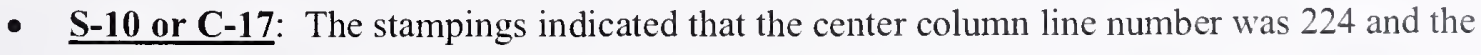
panel spanned floors 92 through 95 ; however, no building information was observed. By reviewing the flange stampings (Table 3-8), the piece was determined to belong to WTC 1 . 
In addition to the overall images taken for record-keeping purposes, the exterior column panels were mapped to indicate how much of the panel was recovered after the collapse. Figure 3-9 displays schematics of typical exterior panels recovered, and Figs. 3-10 and 3-11 show these maps, with the recovered portion indicated, for the identified samples from WTC 1 and WTC 2, respectively. Special note should be given to the fact that these diagrams are drawn as if viewed from the outside of the building. B-1043, B-1044, and C-24 were samples located at the mechanical floors of the building. C-13 and $\mathrm{C}-13 \mathrm{a}$ (pieces of the same exterior panel) and C-14 were exterior wall panels located at the corner of the building.

For the 12 samples identified as core column material (Table 3-3), all but 2 were clearly marked. Figures 3-12 and 3-13 show the portion of column recovered for each individual column from WTC 1 and WTC 2, respectively. Sample C-30 had markings that clearly indicated the building and column; however, the floors were partially obscured: "x04-10x." As the $24 \mathrm{ft}$ section has both connector ends, it spanned only two floors and fit with the floor levels of 104-106. The second sample was C-88b, which did not have any stampings or markings, but was welded to C-88a (identified by stampings). A final sample, C-83, was also found among this group. While no markings were found on the sample, it was recorded as a core column due to its shape, which was very similar to C-90.

There were 13 other wide flange sections that had stampings and/or markings that did not correspond to the code as discussed above (Table 3-4). Instead, there were typically three distinct grouping of numbers and/or letters. Two examples are:

$$
\begin{array}{llll}
\text { Sample C-44: } & \text { "59 } & \text { S } & 563 " \\
\text { Sample M-17: } & \text { "163 } & 9 & 62 "
\end{array}
$$

One piece, C-26 (Fig. 3-14), was distinct among this group in that it was composed of three wide flange sections bolted together at two different angles. The markings on the piece indicated that the wide flanges were $50 \mathrm{ksi}$ steel and came from the 107th floor of WTC 1. Reviewing design drawings, it was found that this piece was a component of the framed floor outside of the core. The as-built location of the other 12 components could not be determined nor confirmed that they were part of the structural steel used in the WTC towers.

Floor trusses were also recovered; however, attempts to identify their specific as-built locations within the buildings were not successful. No stampings were found. Of the 23 pieces held by NIST, 8 are of significant size but are badly tangled and twisted as a result of the collapse and subsequent handling of the material. The remaining pieces consist of shorter sections of chord and rod material in addition to welded sections that connected the trusses to the floor seats.

At present, there are seven samples from WTC 5, all in the GZ-series (see Table A-10). These are coupons that were removed at the WTC site and held by Gilsanz Murray Steficek, LLP. They were subsequently sent to NIST once the Investigation officially began.

No structural elements have been positively identified from WTC 7. However, the columns were fabricated from conventional $36 \mathrm{ksi}, 42 \mathrm{ksi}$, and $50 \mathrm{ksi}$ steel that complied with ASTM International specifications. 


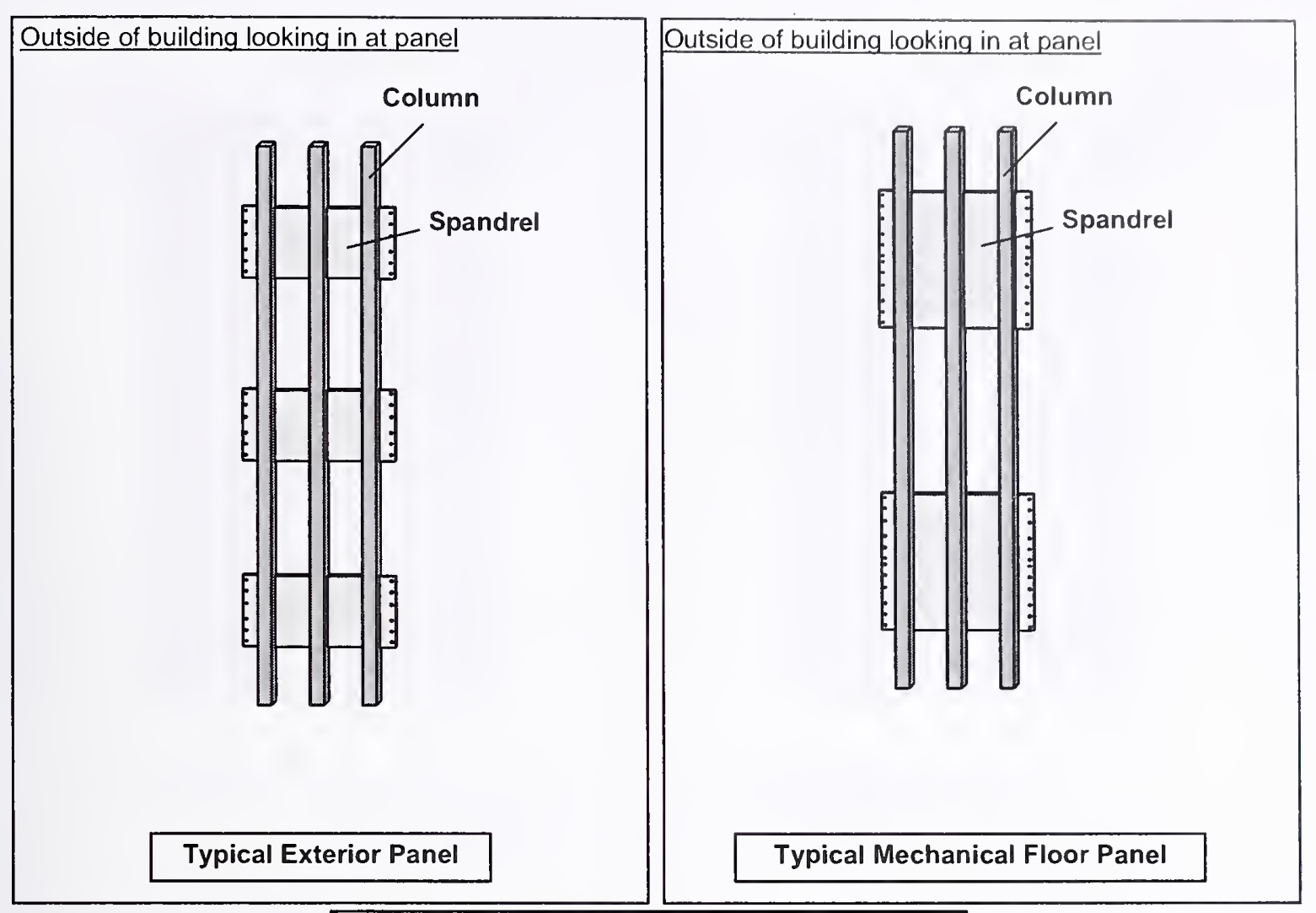

Outside of building looking in at panel

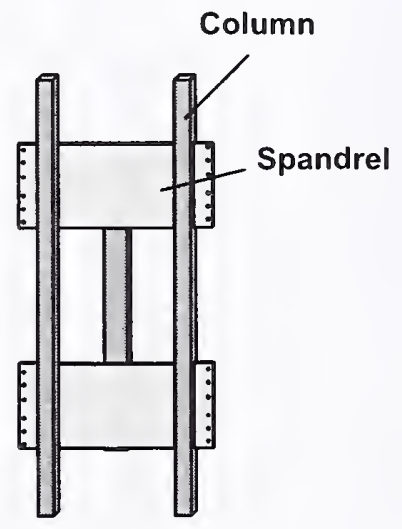

Typical Corner Panel

Figure 3-9. Schematics displaying the various types of exterior column panels. 


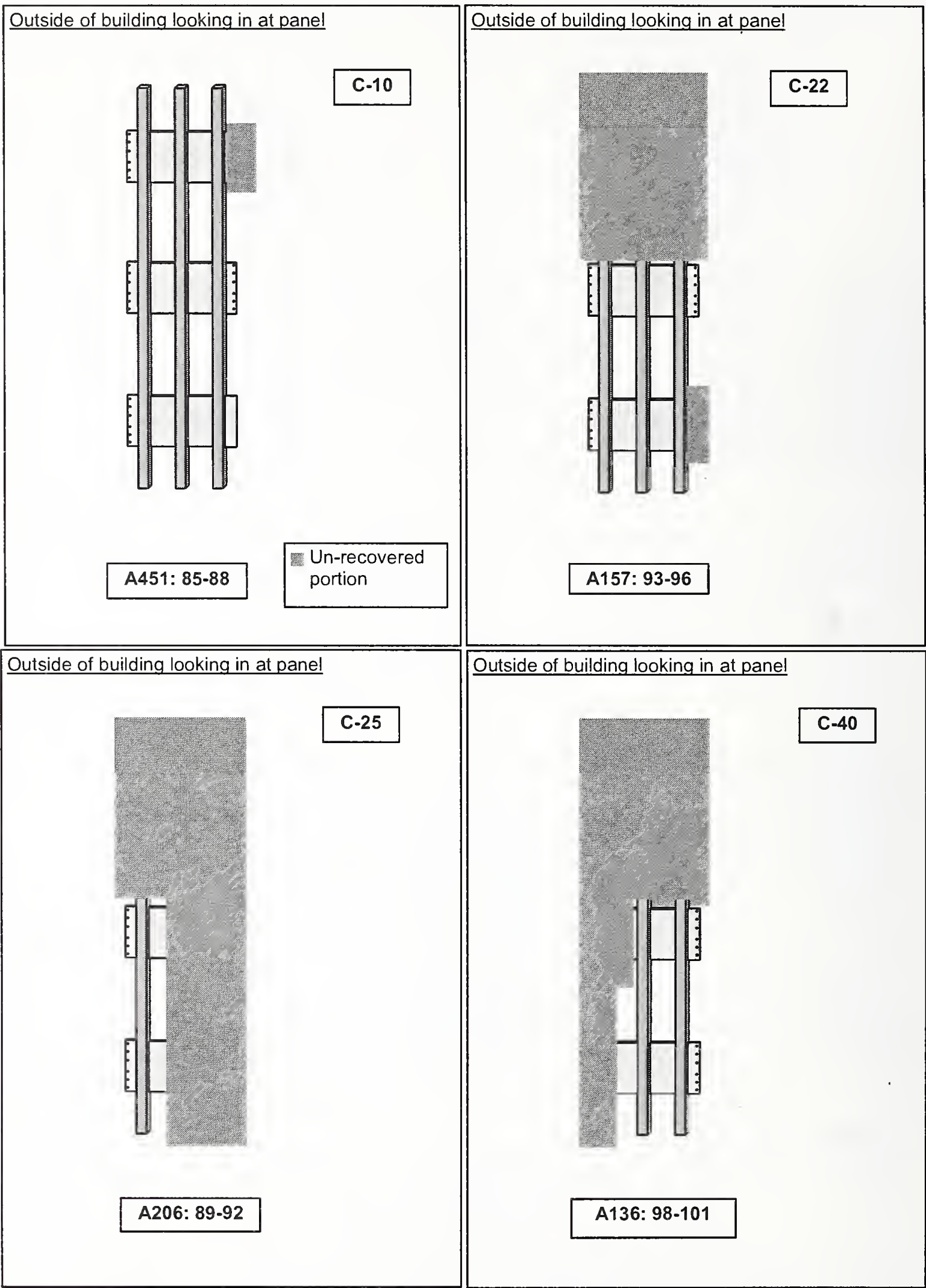

Figure 3-10. Exterior column panel maps indicating the portion of the specific exterior column panel section recovered from WTC 1. 


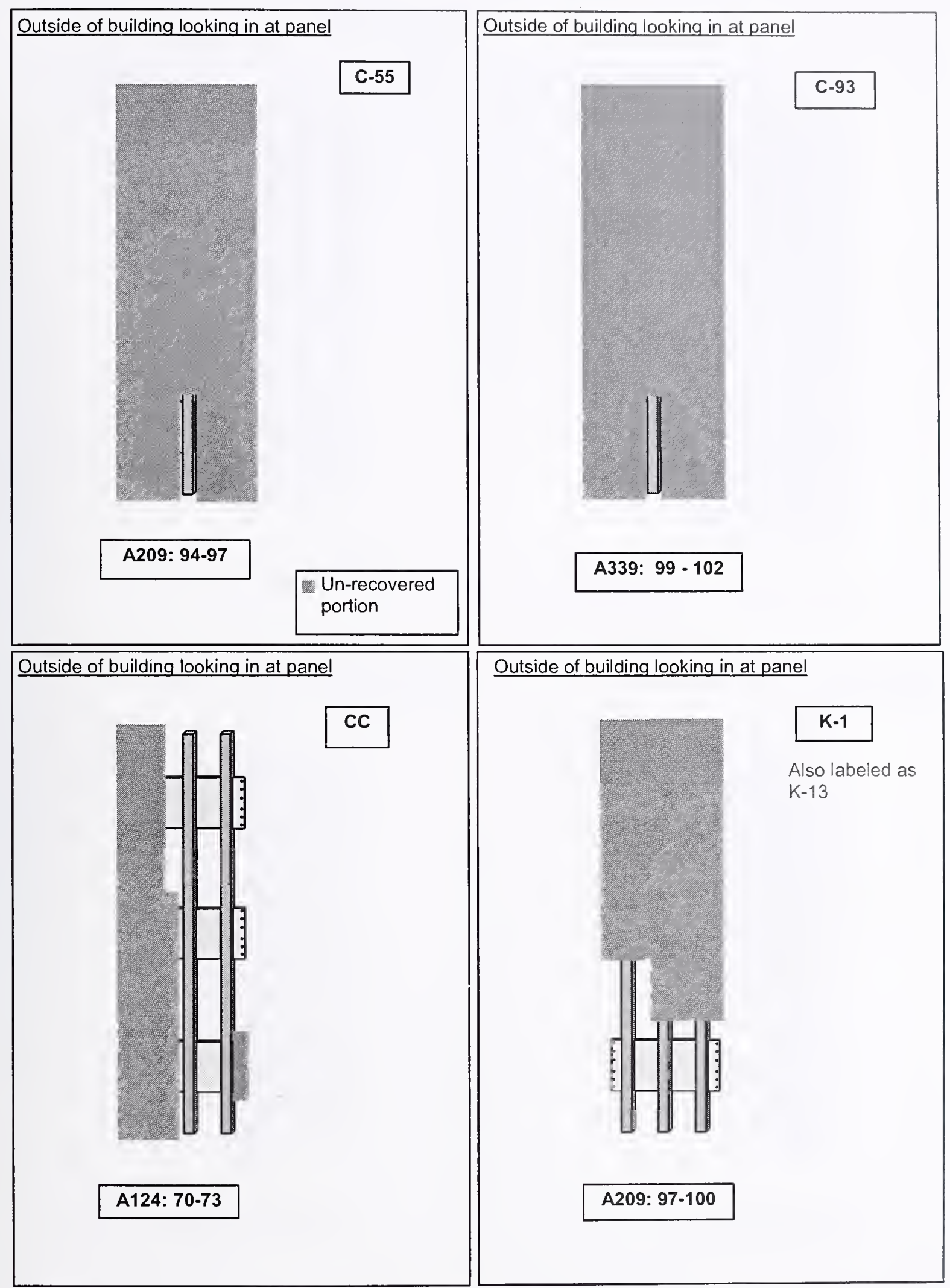

Figure 3-10. Exterior column panel maps indicating the portion of the specific exterior column panel section recovered from WTC 1 (continued). 


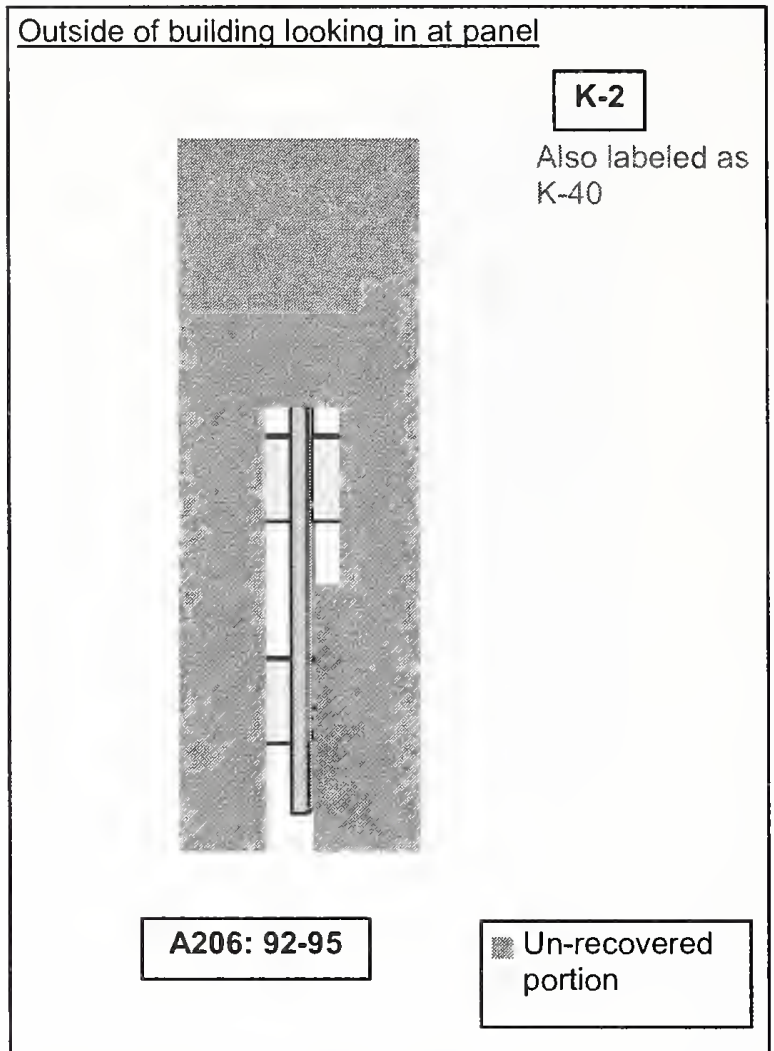

Outside of building looking in at panel

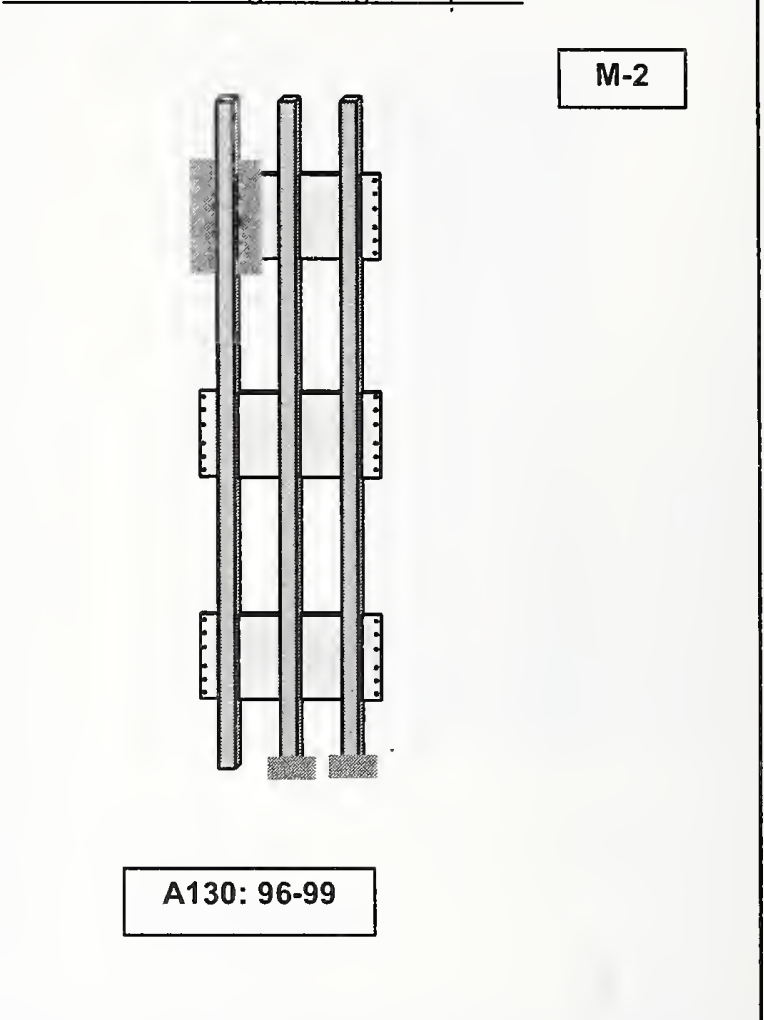

Outside of building looking in at panel

Outside of building looking in at panel
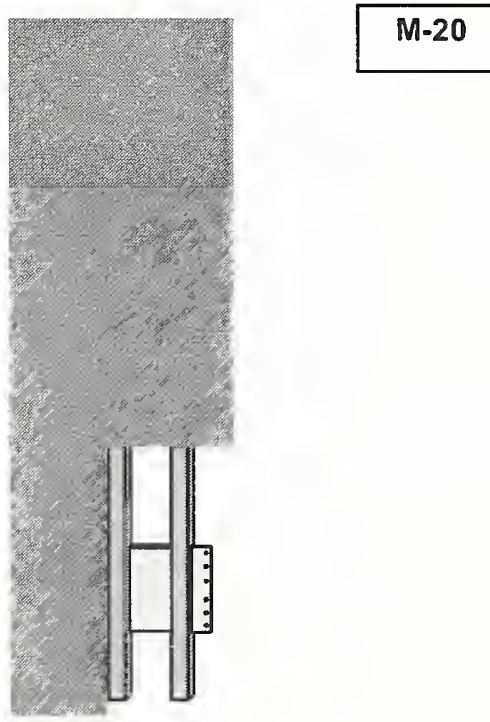

A121: 99-102

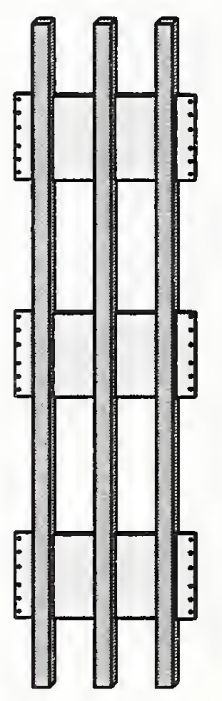

M-26

A130: 90-93

Figure 3-10. Exterior column panel maps indicating the portion of the specific exterior column panel section recovered from WTC 1 (continued). 


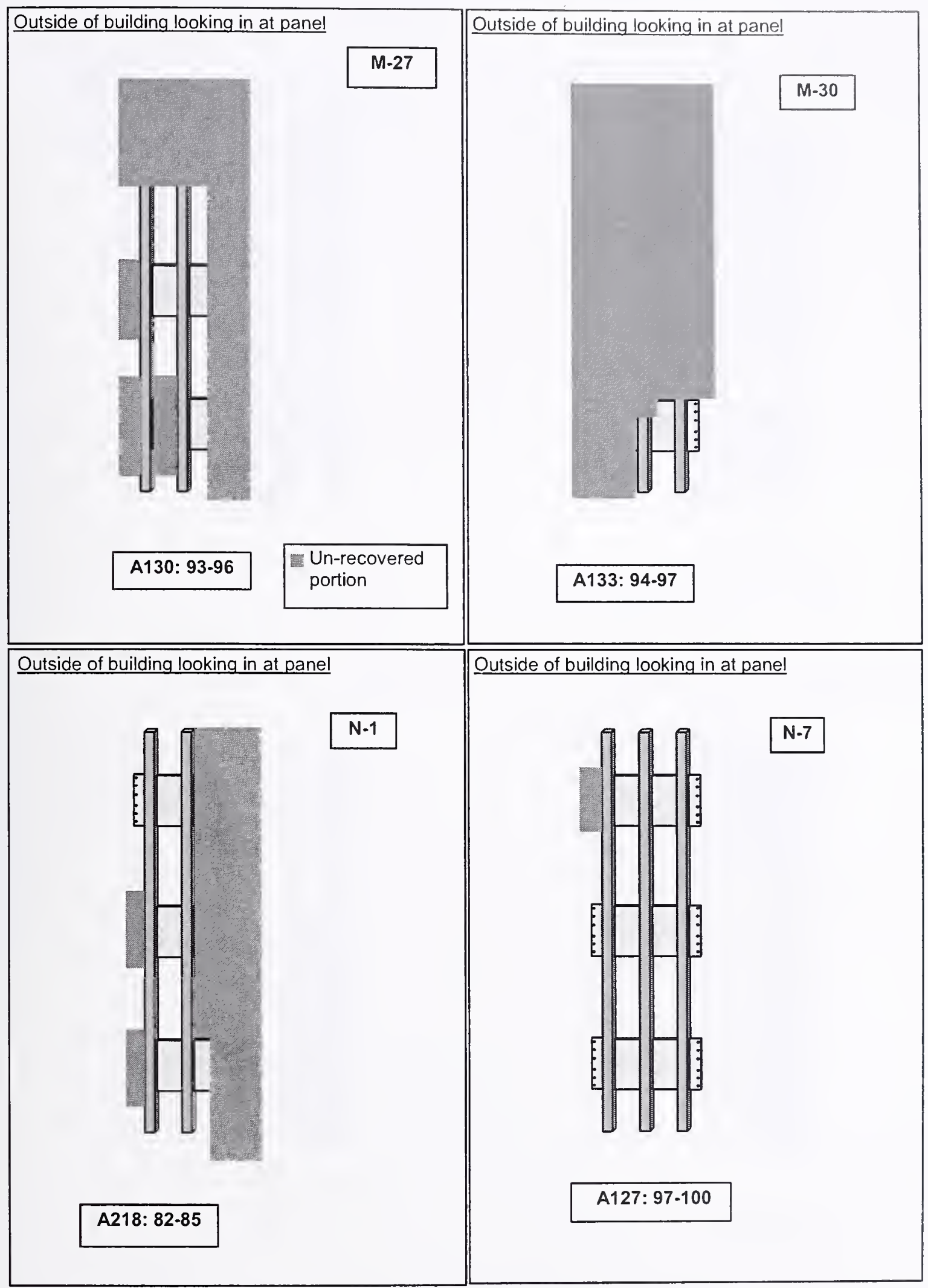

Figure 3-10. Exterior column panel maps indicating the portion of the specific exterior column panel section recovered from WTC 1 (continued). 


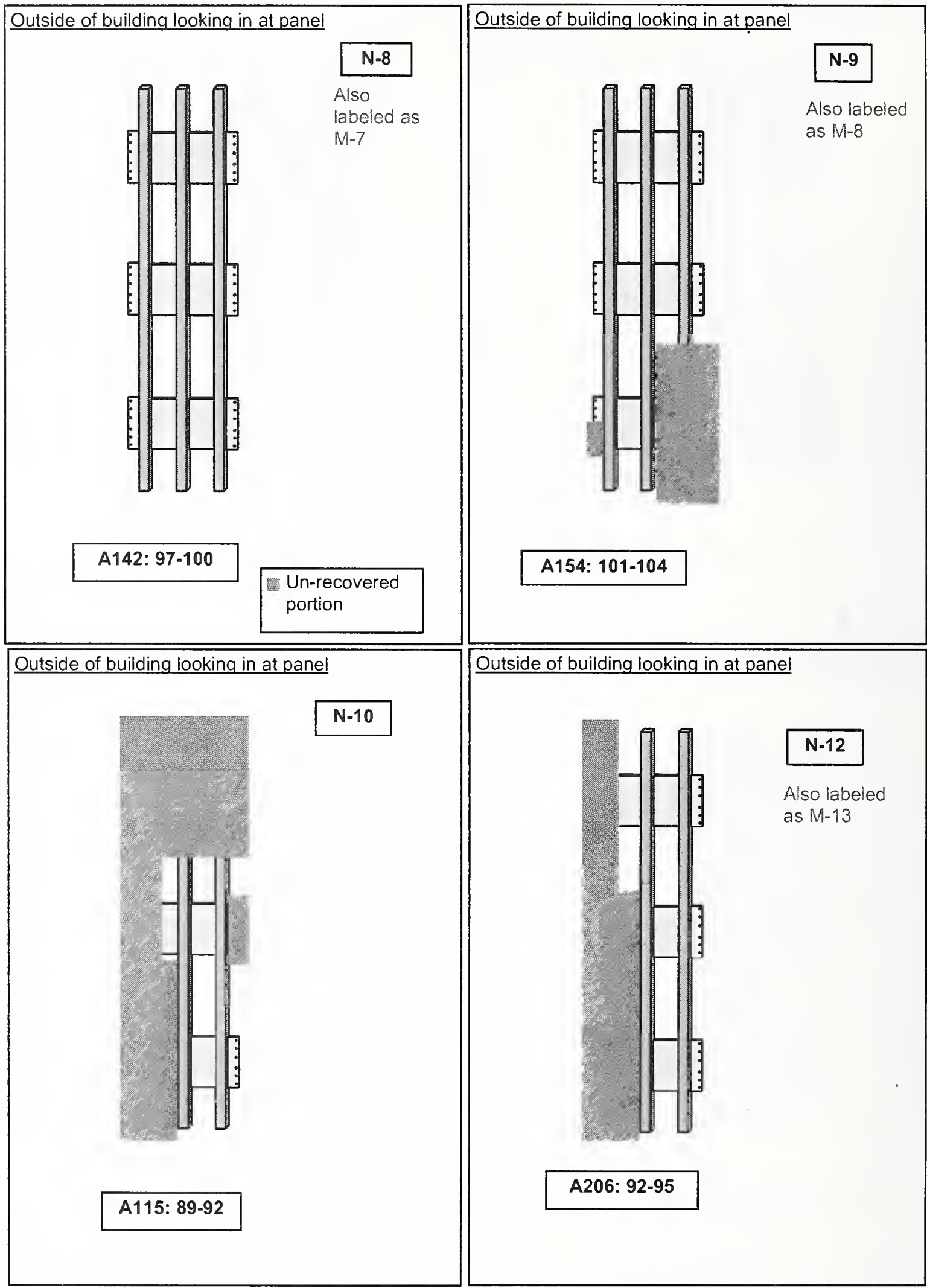

Figure 3-10. Exterior column panel maps indicating the portion of the specific exterior column panel section recovered from WTC 1 (continued). 


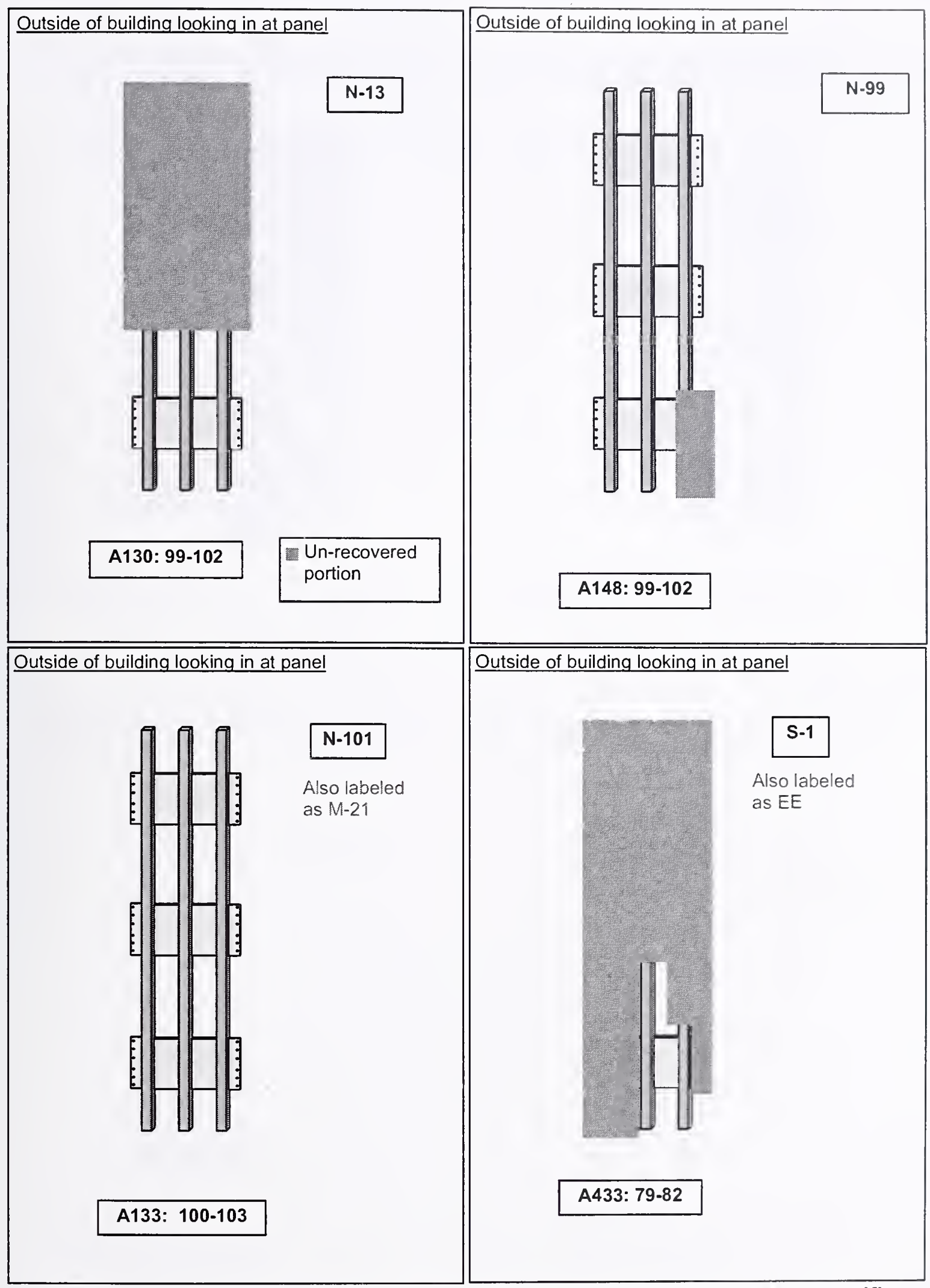

Figure 3-10. Exterior column panel maps indicating the portion of the specific exterior column panel section recovered from WTC 1 (continued). 

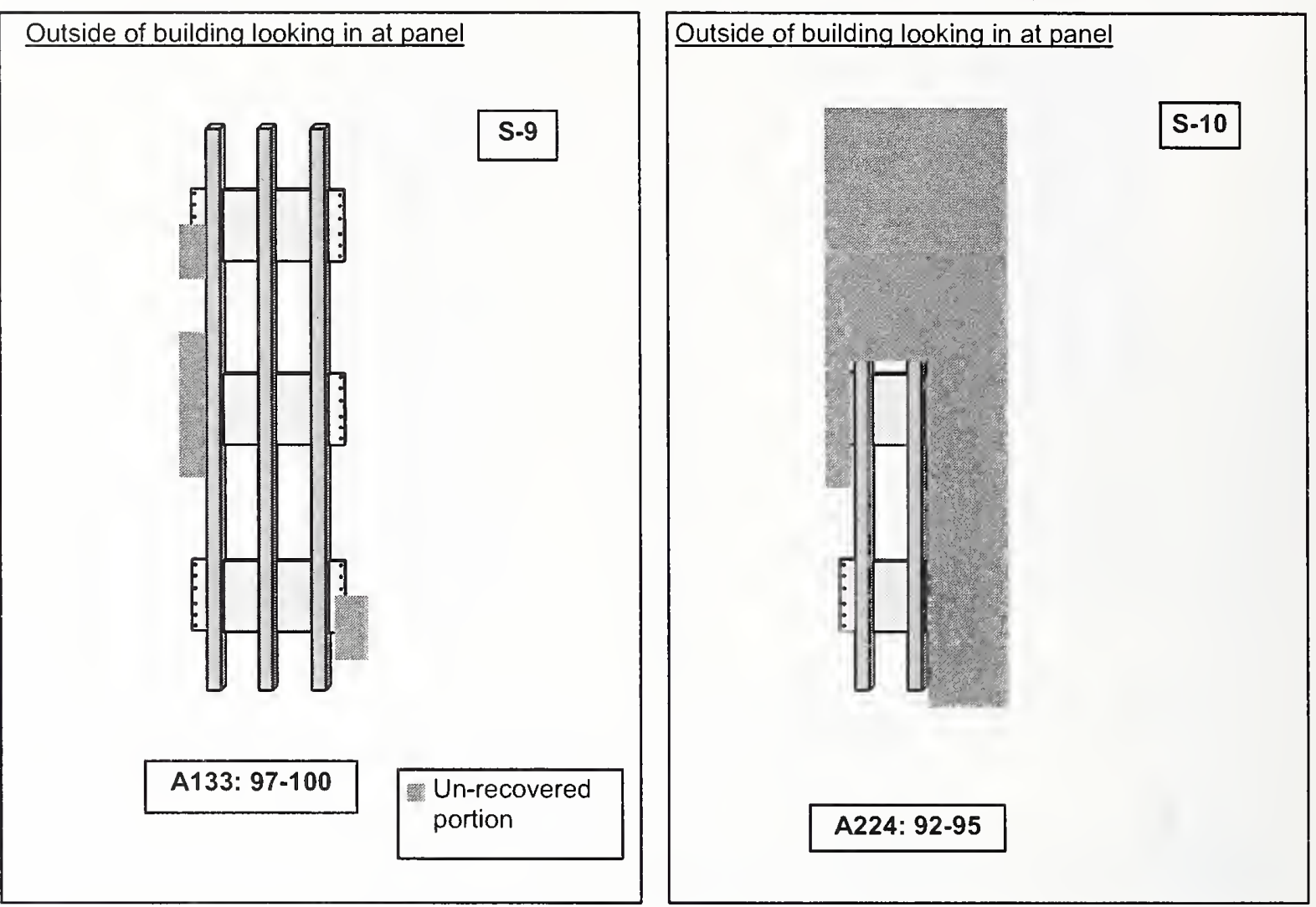

Figure 3-10. Exterior column panel maps indicating the portion of the specific exterior column panel section recovered from WTC 1 (continued). 

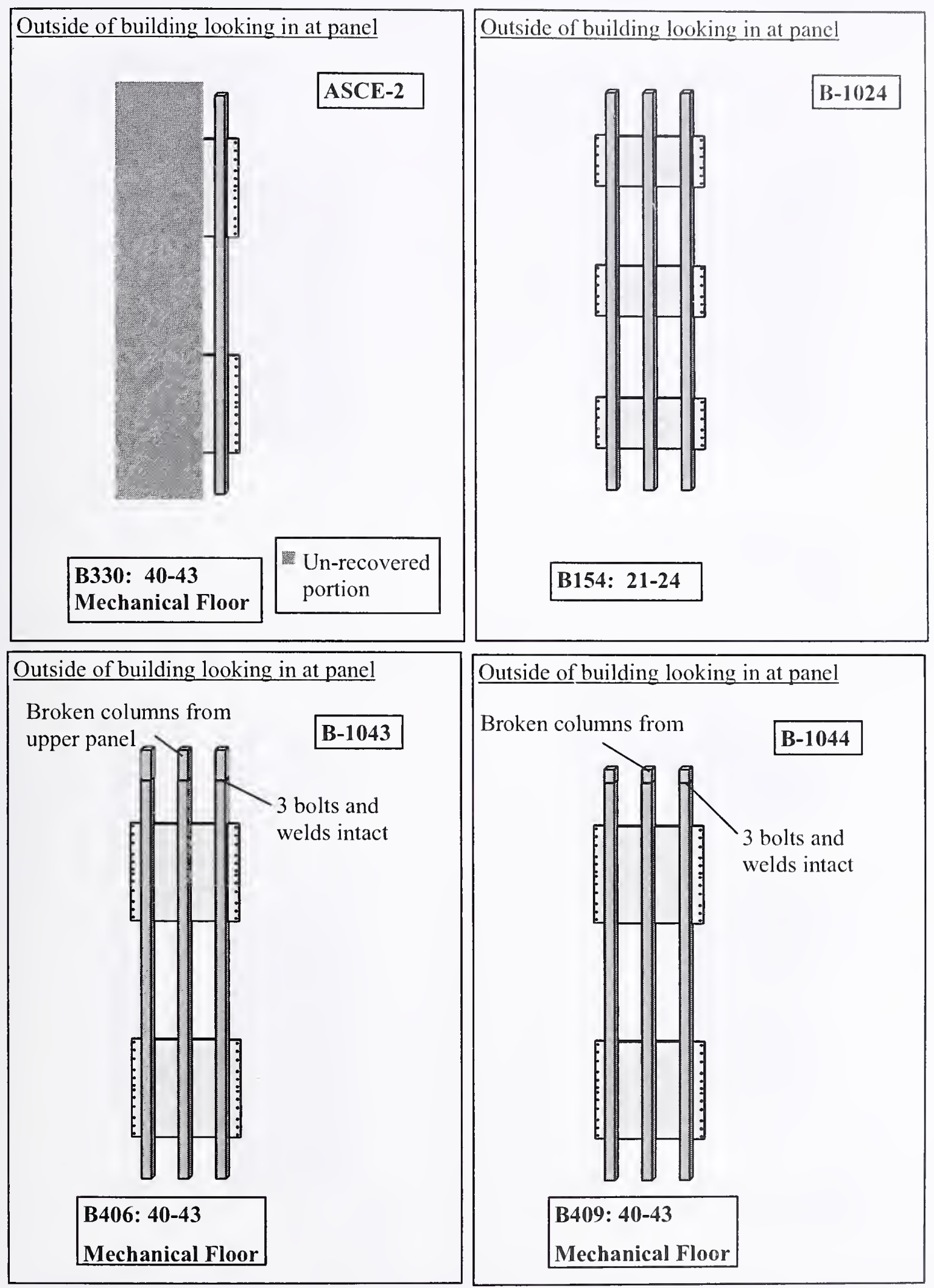

Figure 3-11. Exterior column panel maps indicating the portion of the specific exterior column panel section recovered from WTC 2. 


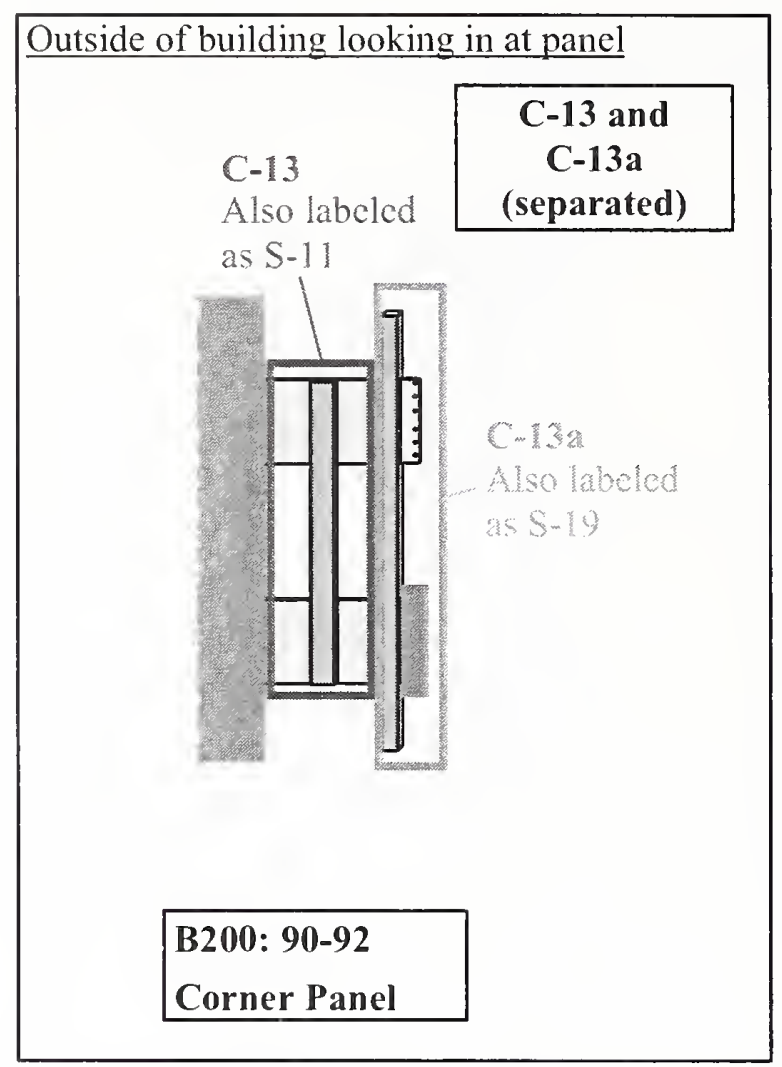

Outside of building looking in at panel
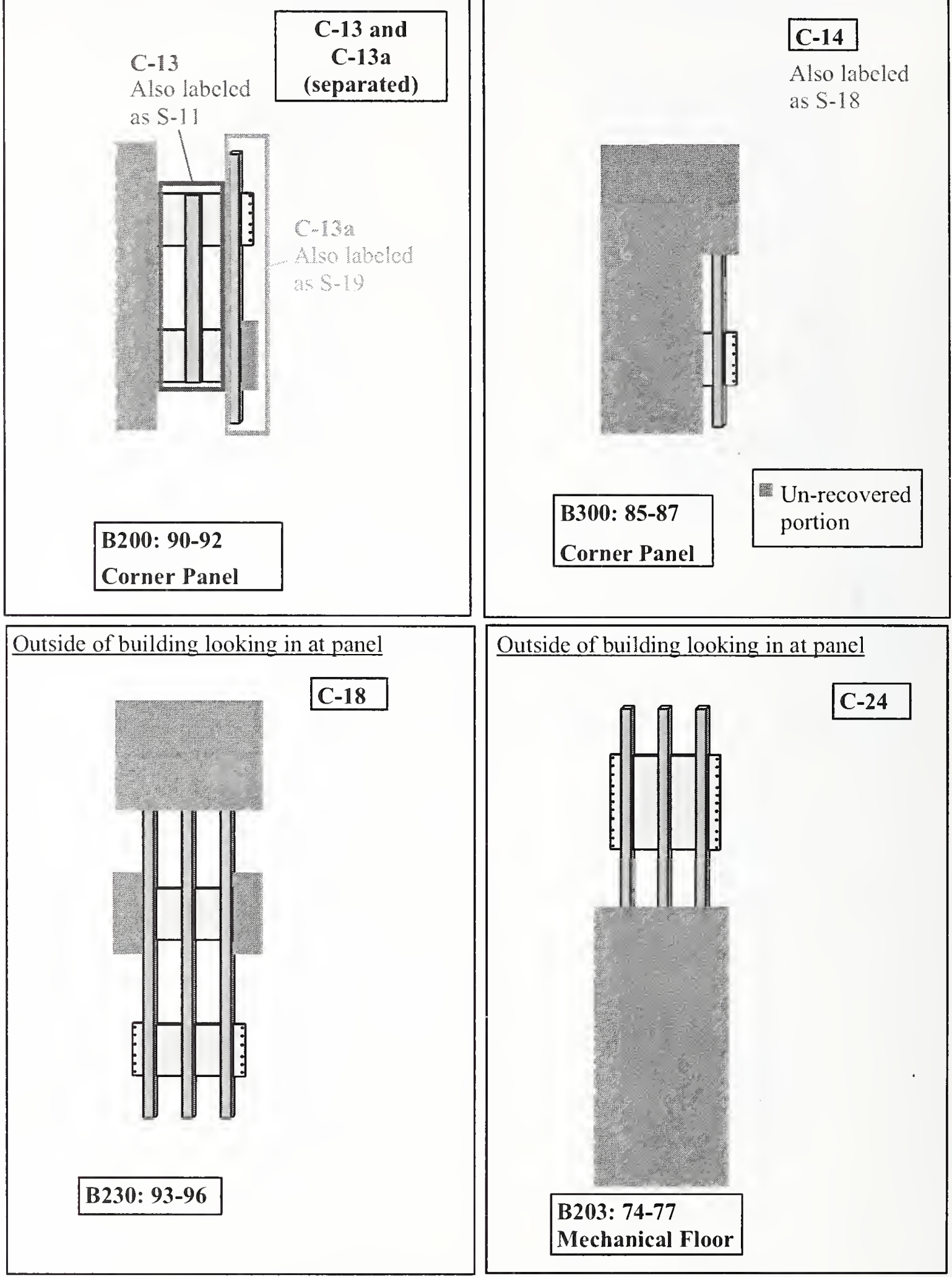

Figure 3-11. Exterior column panel maps indicating the portion of the specific exterior column panel section recovered from WTC 2 (continued). 


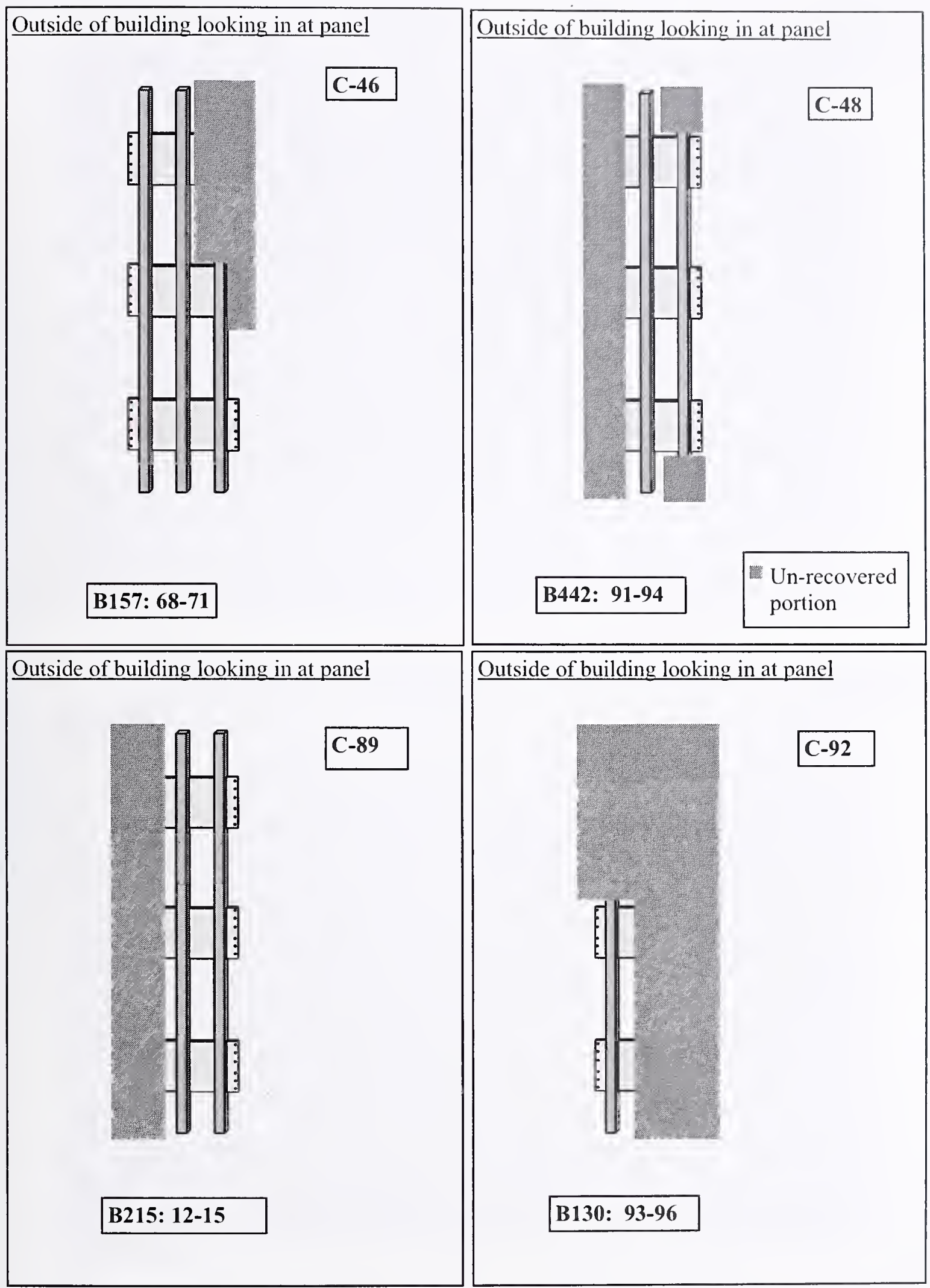

Figure 3-11. Exterior column panel maps indicating the portion of the specific exterior column panel section recovered from WTC 2 (continued). 


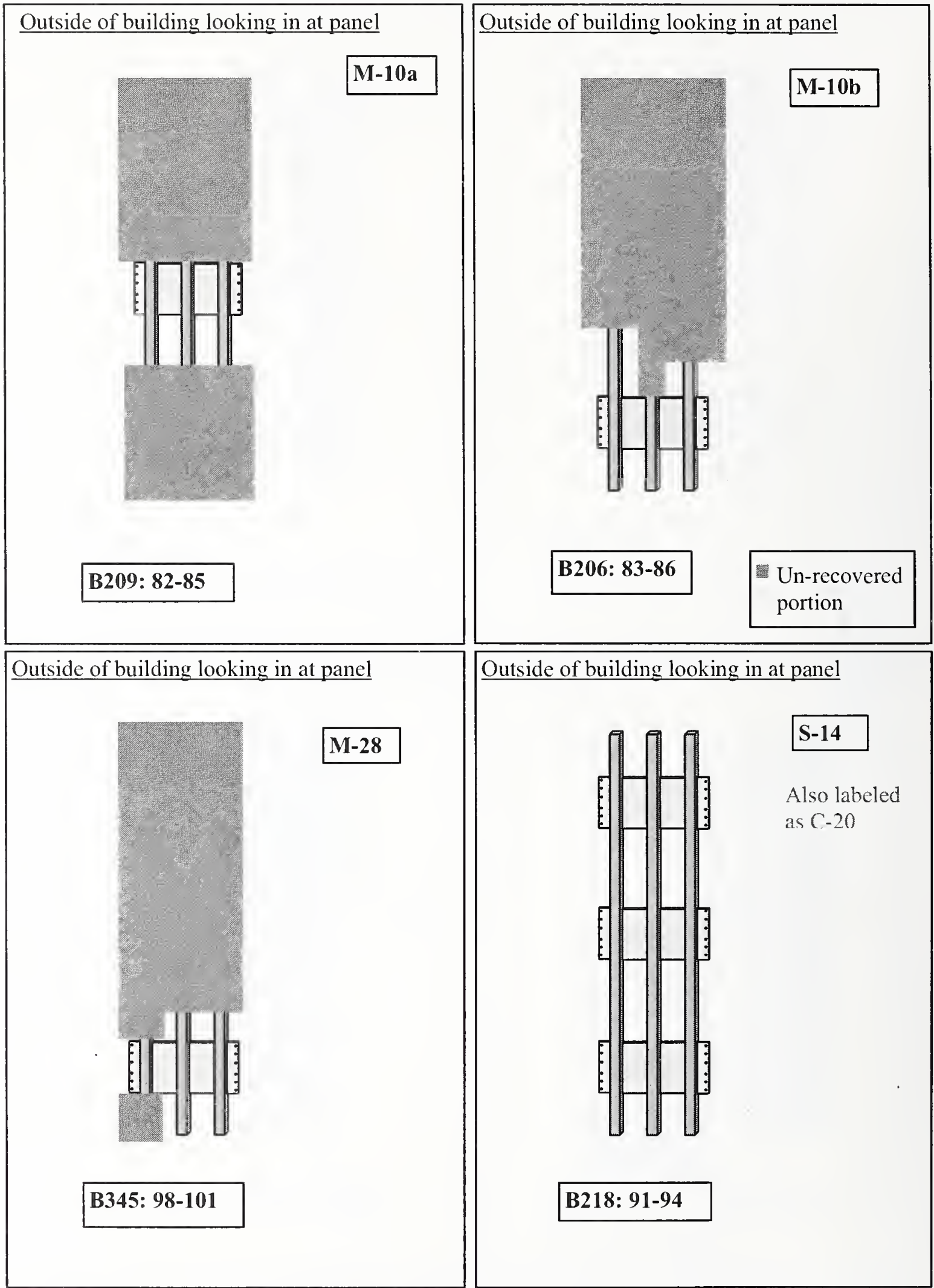

Figure 3-11. Exterior column panel maps indicating the portion of the specific exterior column panel section recovered from WTC 2 (continued). 

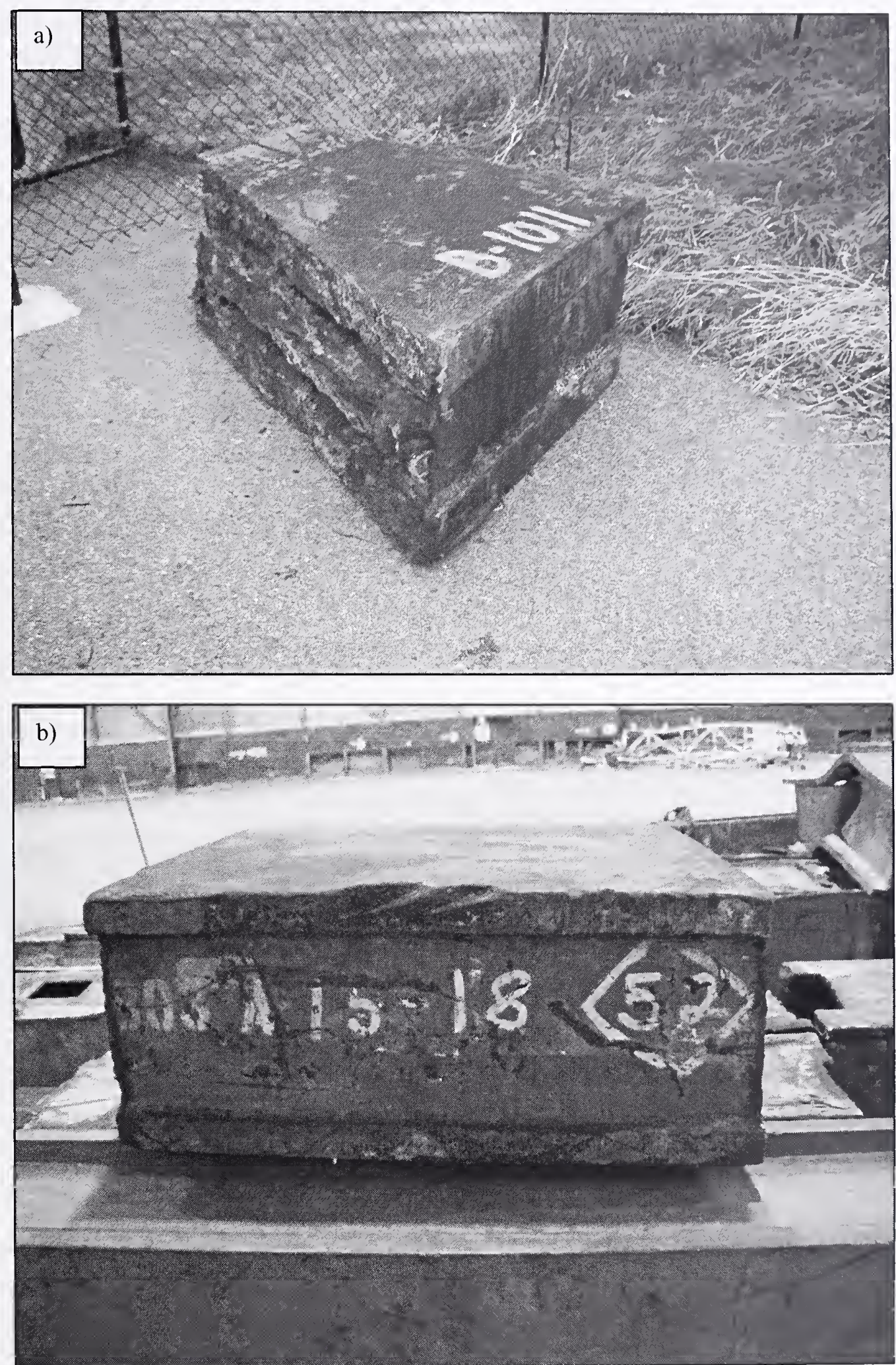

Source: NIST.

Figure 3-12. Core columns recovered from WTC 1. a) B-1011 (508A: 51-54), lower $2 \mathrm{ft}$ to $3 \mathrm{ft}$ of built-up box column, b) B-6152-1 (803A: 15-18), lower $3 \mathrm{ft}$ of built-up box column. 

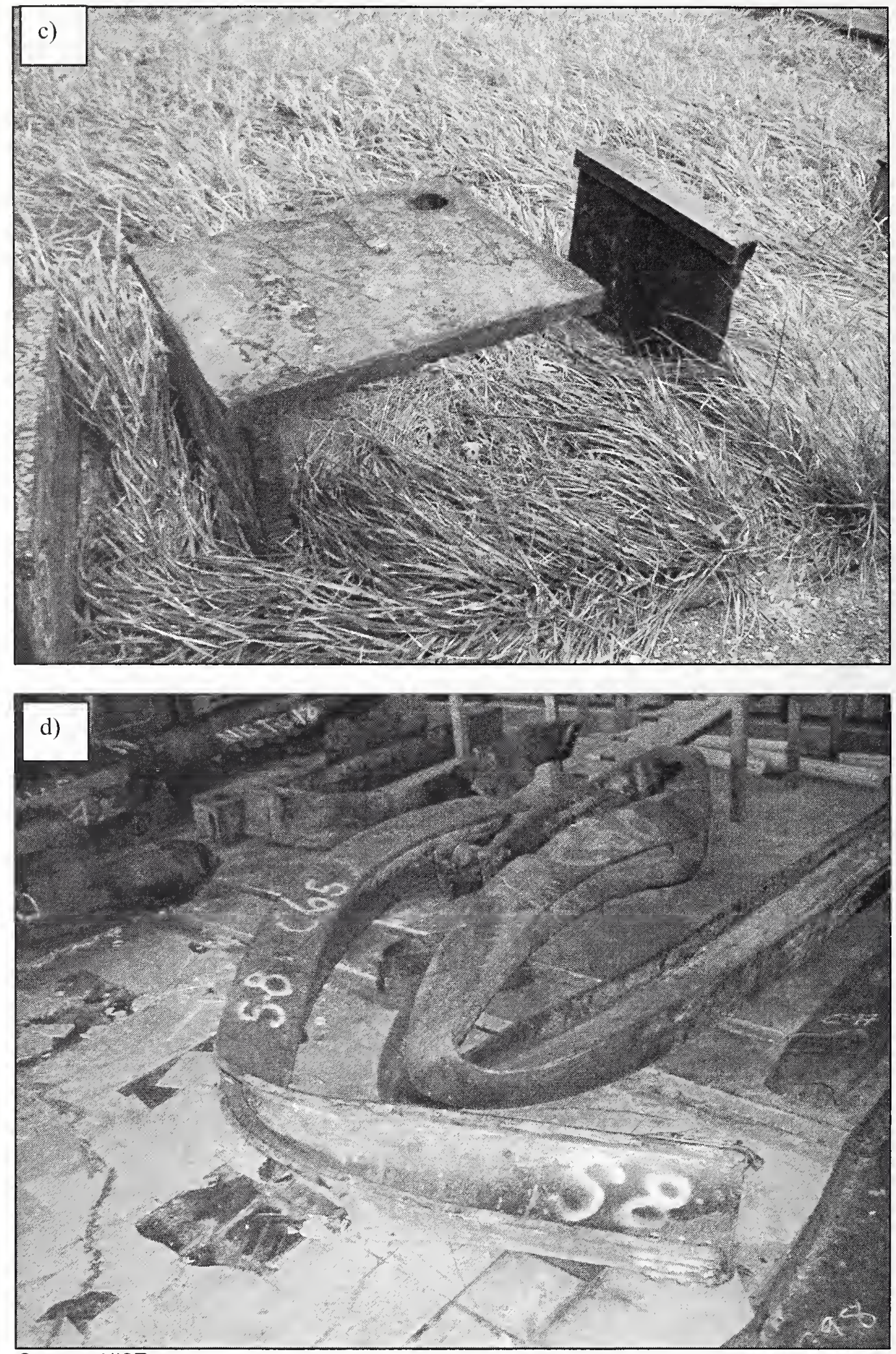

Source: NIST.

Figure 3-12. Core columns recovered from WTC 1. c) B-6152-2 (504A: 33-36), lower $2 \mathrm{ft}$ of built-up box column, d) C-65 (904A: 86-89), lower $24 \mathrm{ft}$ of wide flange section (continued). 

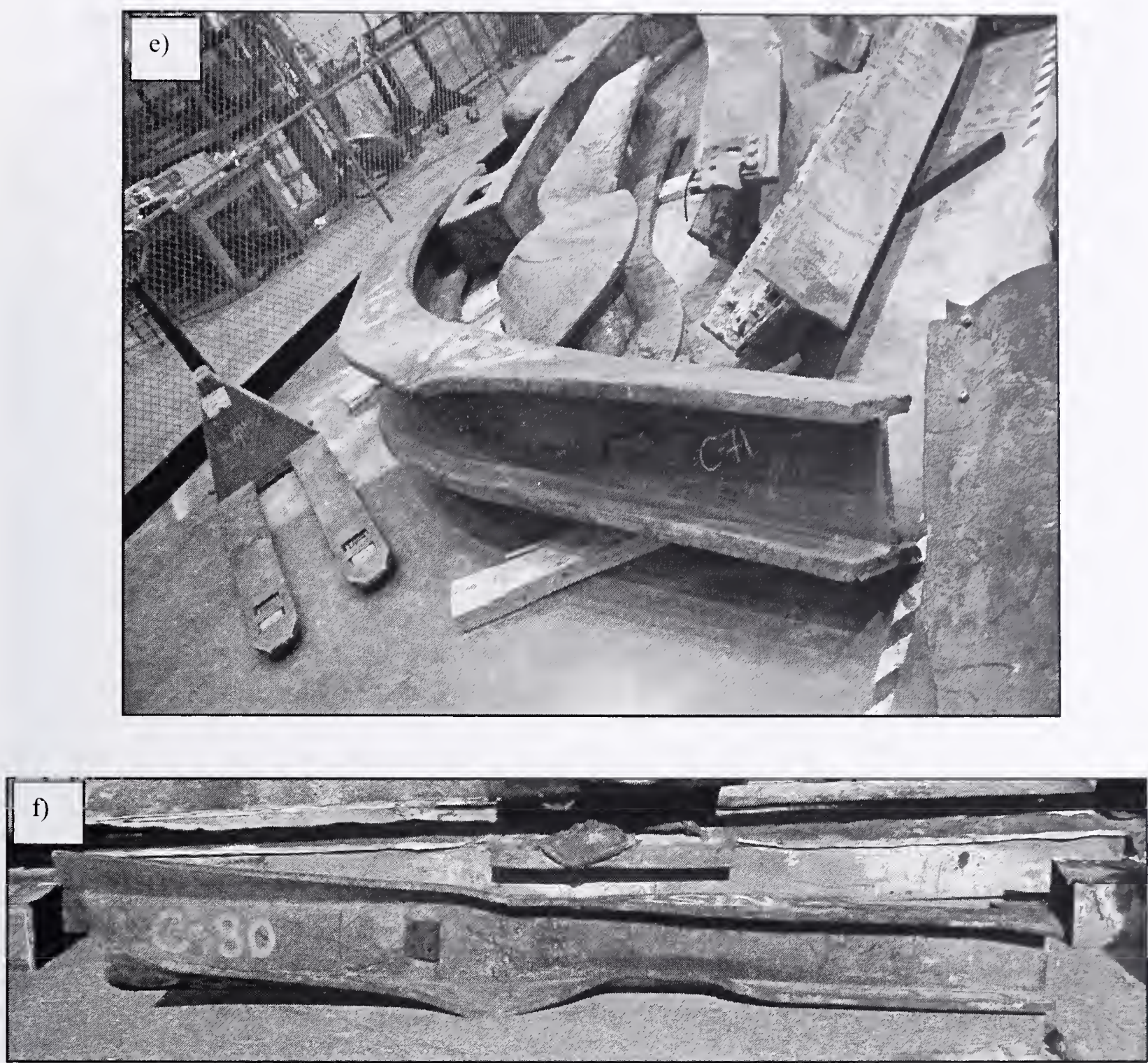

Source: NIST.

Figure 3-12. Core columns recovered from WTC 1. e) C-71 (904A: 77-80), lower $16 \mathrm{ft}$ of wide flange section, f) C-80 (603A: 92-95), lower $13 \mathrm{ft}$ of wide flange section (continued). 

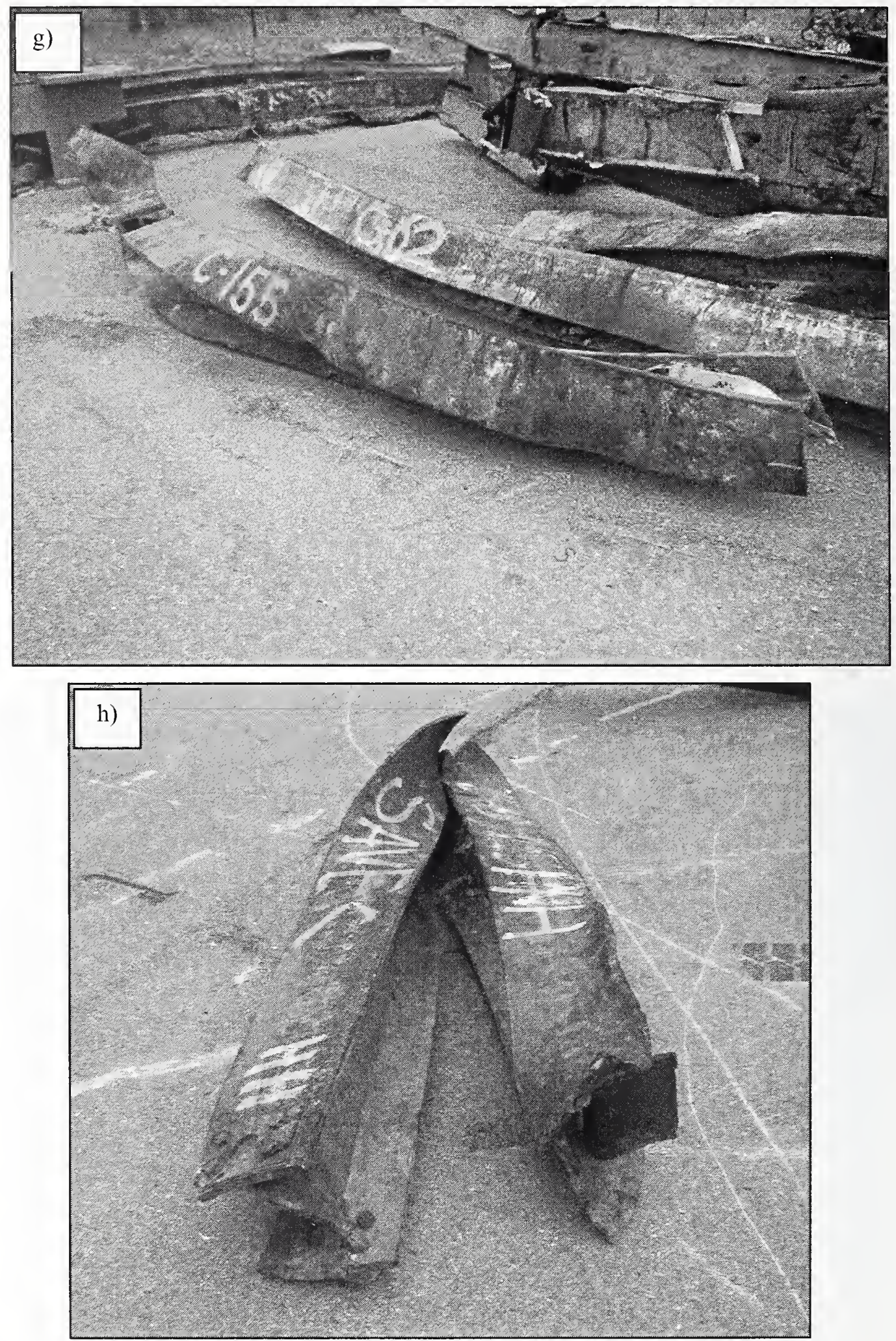

Source: NIST.

Figure 3-12. Core columns recovered from WTC 1. g) C-155

(904A: 83-86), lower $33 \mathrm{ft}$ of wide flange section, and h) $\mathrm{HH}$

(605A: 98-101), lower $16 \mathrm{ft}$ of wide flange section (continued). 


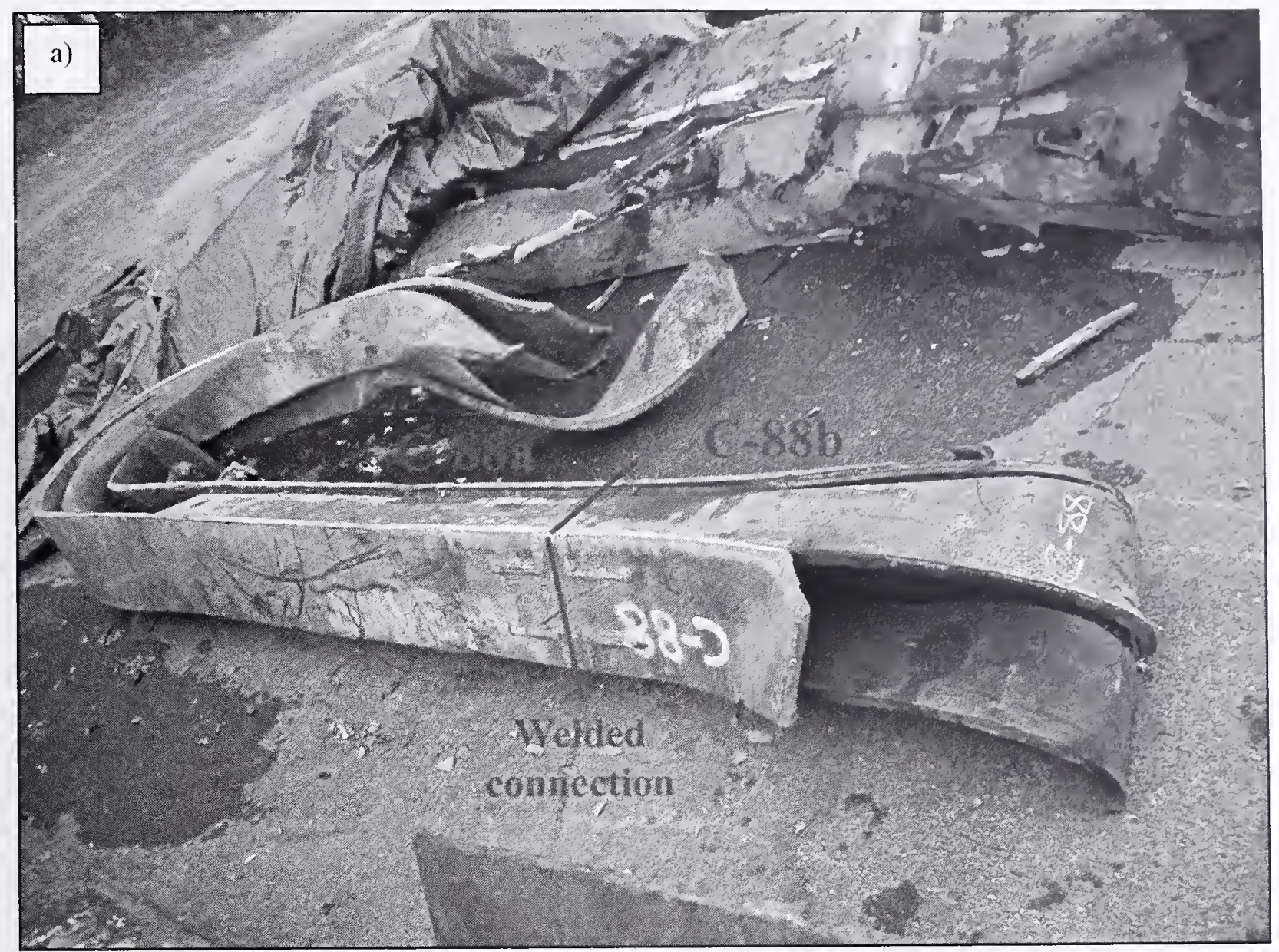

Source: NIST.

Figure 3-13. Core columns recovered from WTC 2. a) C-88a (801B: 80-83), lower $16 \mathrm{ft}$ of built-up box column and C-88b (801B: $77-80$ ), upper $8 \mathrm{ft}$ of built-up box column. 

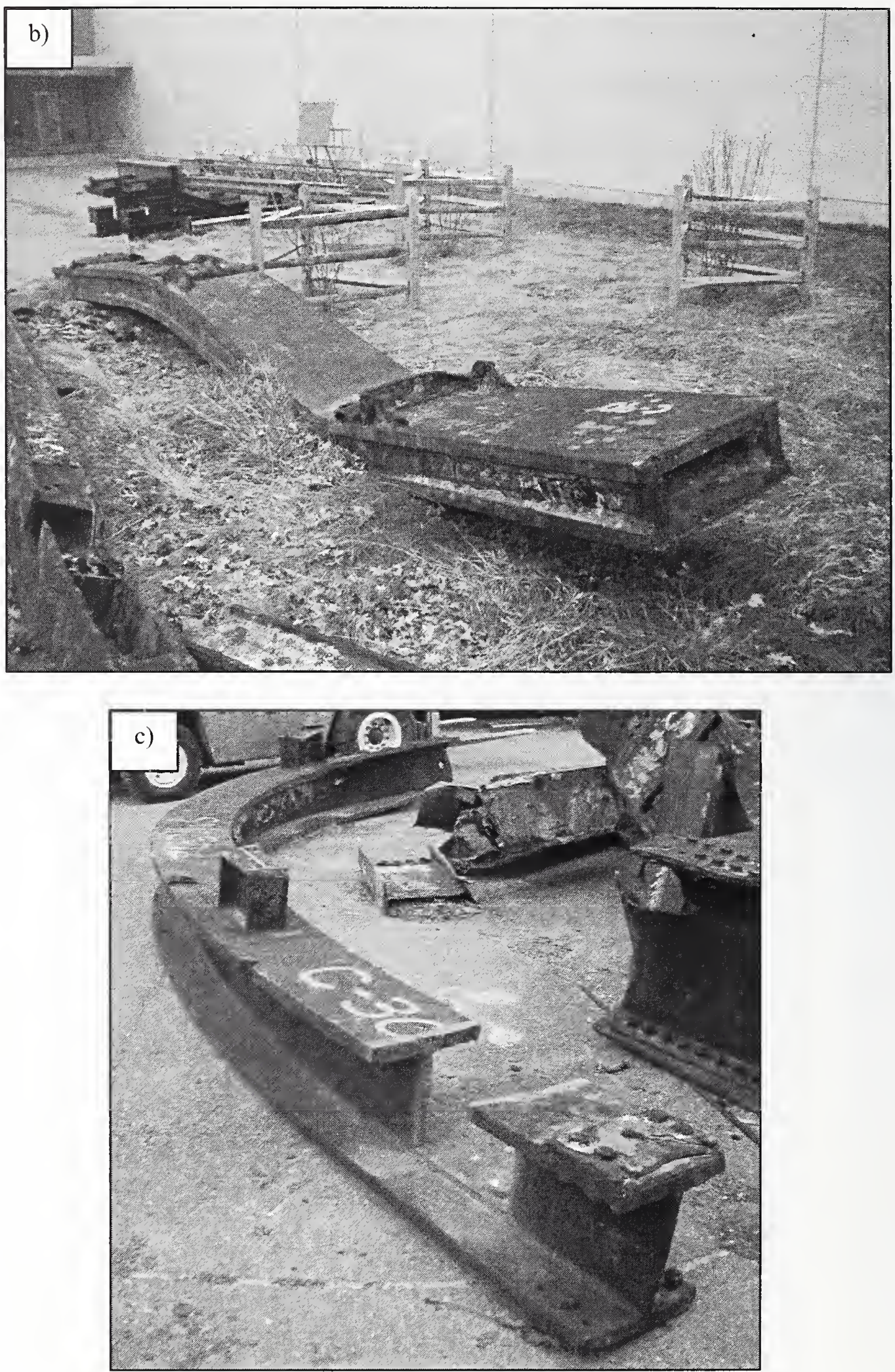

Source: NIST

Figure 3-13. Core columns recovered from WTC 2. b) C-90 (701B: 12-15), entire length of built-up box column, and c) C-30 (1008B: 104-106) entire length of wide flange section (continued). 

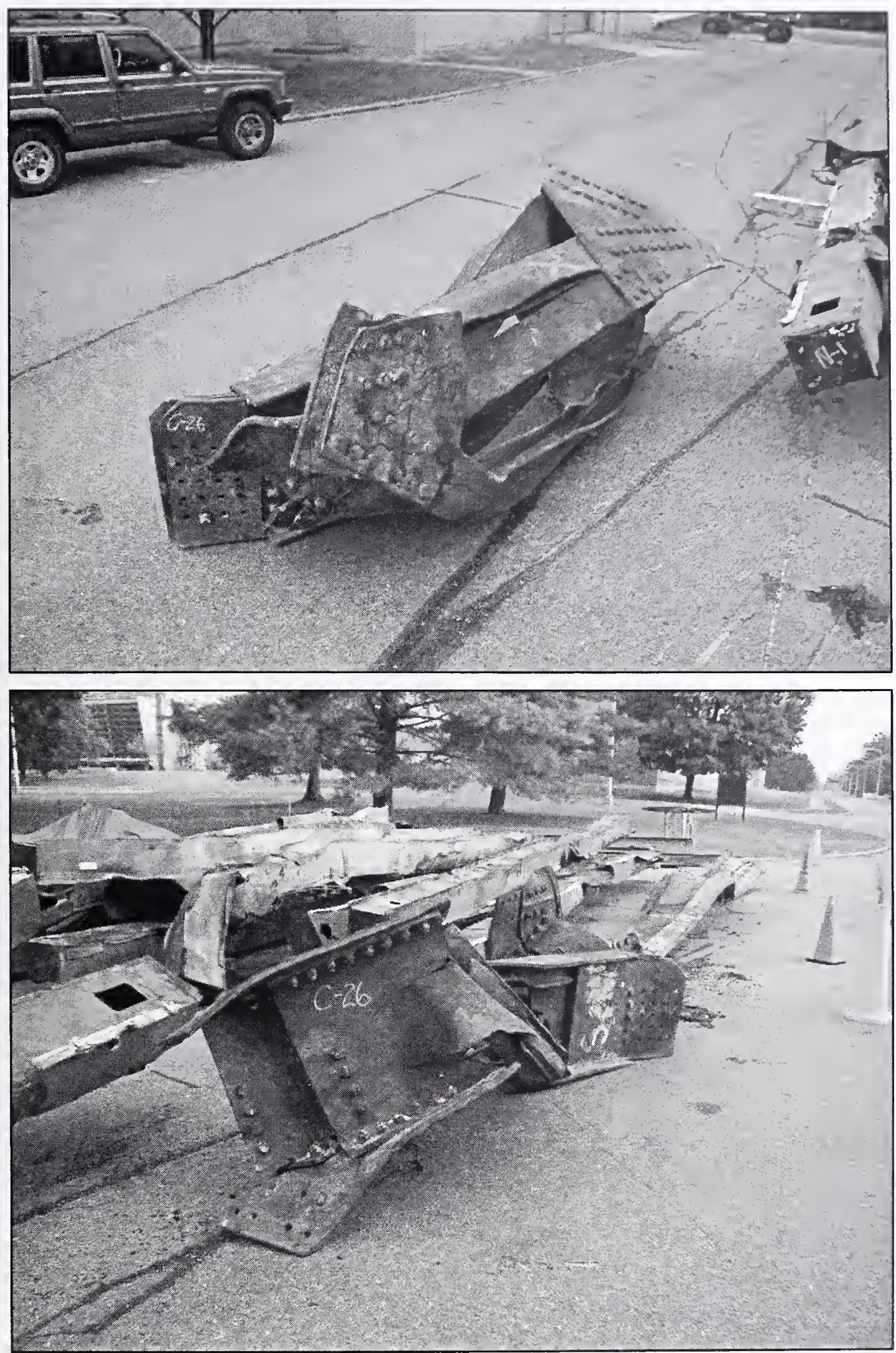

Source: NIST.

Figure 3-14. Structural element composed of three wide flange sections bolted together. The component was found to be from the framed floor area outside of the core on the 107th floor of WTC 1 (sample was C-26). 
This page intentionally left blank. 


\section{Chapter 4 \\ STRUCTURAL SteEl ElEMENTS OF SPECIAL IMPORTANCE}

Of the 41 exterior column pancls and 12 core columns positively identified, many werc considcred especially important to this Investigation led by the National Institute of Standards and Tcchnology (NIST). Two major categories of steel are considered to bc of special valuc:

- Samples located in or around the floors impacted by the airplanc

- Samples that can represent 1 of 12 gradcs of steel spccified for the exterior columns, 1 of 4 grades of steel specified for the core columns, and 1 of the 2 grades of steel for the floor trusses

\subsection{SAMPLES LOCATED IN OR AROUND THE FLOORS IMPACTED BY THE AIRPLANE}

Interpretation of the photographic evidence revealed that damage to World Trade Center (WTC) 1 due to aircraft impact occurred from floor 94 to floor 99 and was bounded by columns 111 through 152. For WTC 2, the impact area was lower with damage found from floor 77 to floor 85 . While the damage appears to be bordercd by column lines 411 and 440 , columns closer to the southeast corner of the building may also have been affected. However, few images were obtaincd where smoke is not obscuring this portion of the south face of WTC 2 to complete the analysis. From this information, NIST was able to determine which perimeter panels and core columns could be used to comment on damage and possible failure mechanisms in this area. Figure 4-1 shows the sample overlay of the exterior panels in NIST's possession in and around the impact zone of WTC 1. Samples C-80 and HH, both core columns, were also identified as residing near the impact zone. The recovered portion of each column is approximately represented in this image. Unfortunately, there were no similar corresponding exterior panels for WTC 2 , but two core columns were recovered (Fig. 4-2). 


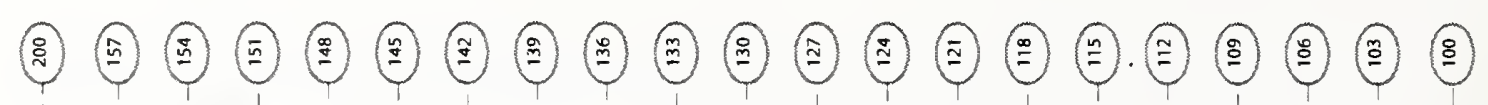

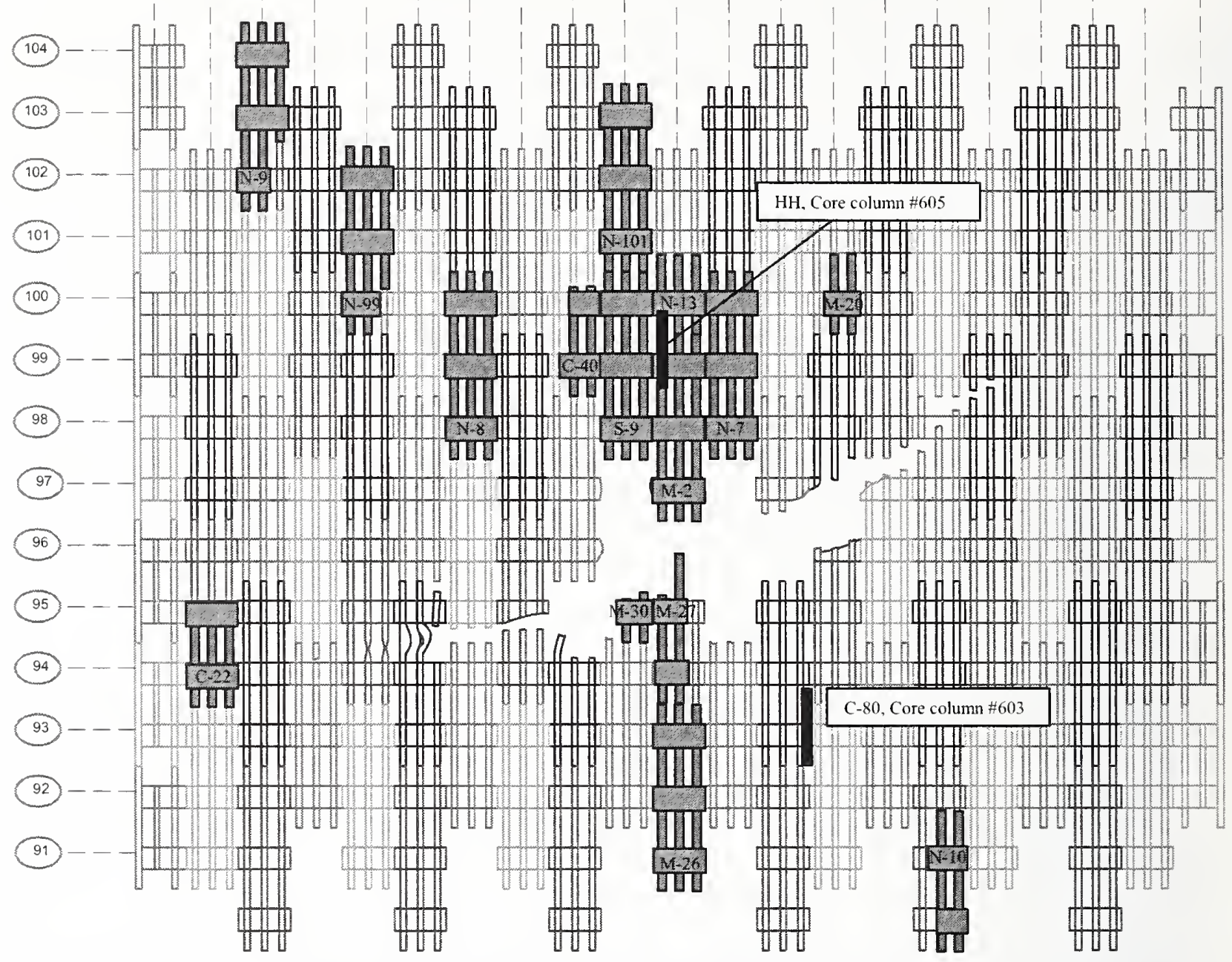

Figure 4-1. Interpreted column damage, from photographic evidence, to WTC 1, with overlay of samples in NIST's possession. Samples shown represent recovered portions. Core columns 603 and 605 are in the second row from the north face of WTC 1. 


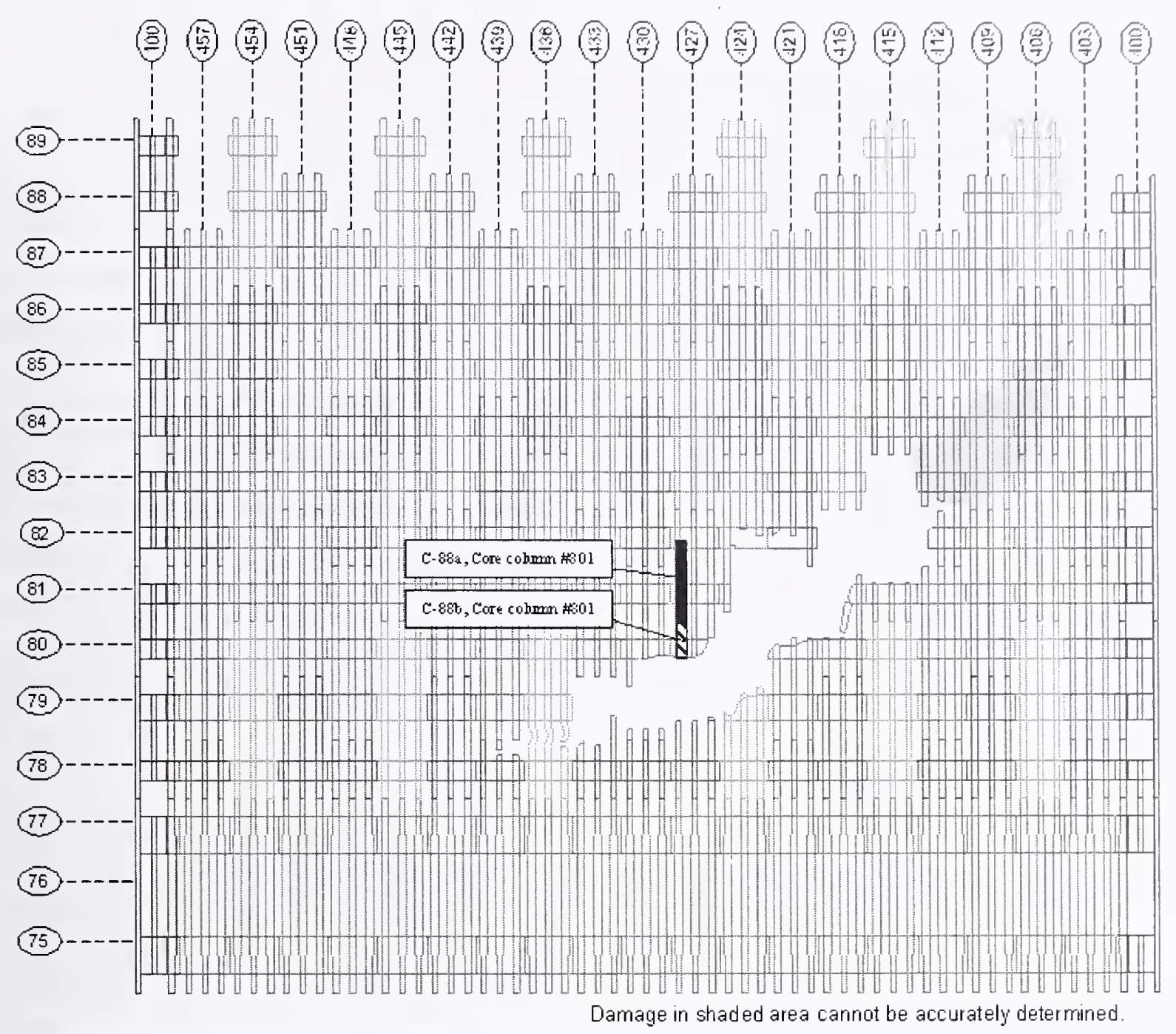

Note: Core column 801 is in the closest row to the south face of WTC 2.

Figure 4-2. Interpreted column damage, from photographic evidence, to WTC 2, with overlay of samples in NIST's possession.

\subsection{SAMPLES REPRESENTING THE VARIOUS TYPES OF STEEL SPECIFIED IN THE DESIGN DRAWINGS}

The other grouping of samples that was deemed important was that which belonged to one of the different grades of steel specified in the buildings' construction. The following minimum yield strengths, in ksi ( 1 ksi equals 1,000 pounds per square inch), were specified for each structural element:

- Columns of the exterior panels: $36,42,45,46,50,55,60,65,70,75,80,85,90$, and 100

- Core columns: $36,42,46$, and 50

- Floor truss material: 36 and 50 
From the recovered steel, sufficient representative samples from each important class of steels are available for a full examination (i.e., chemical, metallurgical, and mechanical property analyses). From Table 4-1, it can be seen that 10 of the 14 types of steel specified for the columns are represented, and 10 of the 12 grades of spandrel material have been identified. Additionally, sample ASCE-3 (as-built location in the building not identified) has a flange stamping of 45 for the minimum yield requirement, which would increase the total number of perimeter column material types to 11 . One important note is that from the observed stampings of the recovered elements and other documents (see NIST

NCSTAR 1-2B), it appears that $100 \mathrm{ksi}$ steel was substituted for the $85 \mathrm{ksi}$ and $90 \mathrm{ksi}$ grades in the construction of the exterior panels (Table 3-6). Considering both column and spandrel material, samples of all grades specified for the perimeter panels are available for metallurgical and mechanical property evaluation. There are a total of 106 individual perimeter columns ( 97 columns with known as-built locations and 9 columns from unidentified panels sections where the column type and minimum strength values could be deciphered from the stampings located on the base of the columns) and 87 pieces of spandrel material. Tables 4-2 and 4-3 list the specified minimum yield strength/gauge combinations recovered for the columns and spandrels, respectively. While only two of the four grades of steels were obtained (36 ksi and $42 \mathrm{ksi}$ ) for the core columns (Table 3-3), 99 percent of the total number of core columns were fabricated from these two grades. For the floor truss material, the samples could not be identified as to their precise, as-built locations within the buildings. However, initial chemical and mechanical property analyses have shown that both minimum yield strength materials specified have been recovered. 
Table 4-1. Listing of recovered exterior column panels with specified minirnum yield strengths and thickness for columns ${ }^{\mathrm{a}}$ and spandrels.

\begin{tabular}{|c|c|c|c|c|c|c|c|c|c|c|c|c|c|c|c|c|c|}
\hline \multirow{2}{*}{$\begin{array}{c}\text { NIST } \\
\text { NAME }\end{array}$} & \multirow{2}{*}{ Bldg } & \multirow{2}{*}{$\begin{array}{l}\text { Center } \\
\text { Col. \# }\end{array}$} & \multicolumn{2}{|c|}{$\begin{array}{l}\text { Splice at } \\
\text { floor }\end{array}$} & \multirow{2}{*}{$\begin{array}{c}\text { Panel } \\
\text { Type }\end{array}$} & \multicolumn{2}{|c|}{$\begin{array}{c}\text { COLUMN } \\
1 \\
\end{array}$} & \multicolumn{2}{|c|}{$\begin{array}{c}\text { COLUMN } \\
2 \\
\end{array}$} & \multicolumn{2}{|c|}{$\begin{array}{c}\text { COLUMN } \\
3 \\
\end{array}$} & \multicolumn{2}{|c|}{$\begin{array}{c}\text { LOWER } \\
\text { SPANDREL }\end{array}$} & \multicolumn{2}{|c|}{$\begin{array}{c}\text { MIDDLE } \\
\text { SPANDREL }\end{array}$} & \multicolumn{2}{|c|}{$\begin{array}{c}\text { UPPER } \\
\text { SPANDREL }\end{array}$} \\
\hline & & & Lower & Upper & & $\begin{array}{l}\text { Col. } \\
\text { type }\end{array}$ & $\begin{array}{c}\text { Fy } \\
\text { (ksi) }\end{array}$ & $\begin{array}{l}\text { Col. } \\
\text { type }\end{array}$ & $\begin{array}{c}\text { Fy } \\
\text { (ksi) }\end{array}$ & $\begin{array}{l}\text { Col. } \\
\text { type }\end{array}$ & $\begin{array}{c}\text { Fy } \\
\text { (ksi) }\end{array}$ & $\begin{array}{l}\text { Cage } \\
\text { (in) }\end{array}$ & $\begin{array}{c}\text { Fy } \\
\text { (ksi) }\end{array}$ & $\begin{array}{c}\text { Cage } \\
\text { (in) }\end{array}$ & $\begin{array}{c}\text { Fy } \\
\text { (ksi) }\end{array}$ & $\begin{array}{l}\text { Gage } \\
\text { (in) }\end{array}$ & $\begin{array}{c}\text { Fy } \\
\text { (ksi) }\end{array}$ \\
\hline B-1024 & WTC 2 & 154 & 21 & 24 & 300 & 152 & 50 & 150 & 50 & 149 & 50 & 1.25 & 36 & 1.25 & 36 & 125 & 36 \\
\hline$A_{\triangle} S C E-2$ & WTC 2 & 330 & 40 & 43 & 400 & 356 & 50 & 356 & $5 \theta$ & 356 & $\leqslant \theta$ & 0.938 & 36 & n'a & rda & 0.938 & 45 \\
\hline $\mathrm{CC}$ & WTC 1 & 124 & 70 & 73 & 300 & 133 & 50 & 133 & 50 & 133 & 50 & 0.5625 & 36 & 0.5625 & 36 & 0.5625 & 36 \\
\hline M-26 & WTC 1 & 130 & 90 & 93 & 300 & 125 & 50 & 125 & 55 & 125 & 50 & 0.375 & 36 & 0.375 & 36 & 0.375 & 36 \\
\hline $\mathrm{M}-27$ & WTC 1 & 130 & 93 & 96 & 300 & 123 & 55 & 123 & 55 & 124 & 50 & 0.375 & 36 & 0.375 & 36 & Q-375 & 36 \\
\hline$M-2$ & WTC 1 & 130 & 96 & 99 & 300 & 122 & 55 & 122 & 55 & 122 & 55 & 0.375 & 36 & 0.375 & 42 & 0.375 & 36 \\
\hline$M-30$ & WTC 1 & 133 & 94 & 97 & 300 & 123 & 55 & 123 & 55 & 123 & 55 & 0.375 & 36 & 0.375 & 36 & 9.375 & $4 z$ \\
\hline C-18 & WTC 2 & 230 & 93 & 96 & 300 & 120 & 55 & 120 & 55 & 120 & 55 & 0.375 & 45 & 0.375 & 42 & 9.375 & $4 z$ \\
\hline$N-9$ & WTC 1 & 154 & 101 & 104. & 300 & 120 & 55 & 120 & 55 & 120 & 55 & 0.375 & 42 & 0.375 & 36 & 0.375 & 36 \\
\hline$M-20$ & WTC 1 & 121 & 99 & 102 & 300 & 120 & 5.5 & 120 & 55 & 120 & 55. & 0.375 & 42 & 0.375 & $4 z$ & 0.375 & 36 \\
\hline $\mathrm{N}-13$ & WTC 1 & 130 & 99 & 102 & 300 & 120 & 55 & 121 & 55 & 121 & 55 & 0.375 & 42 & 0.375 & $4 z$ & Q.375 & 36 \\
\hline$N-101$ & WTC 1 & 133 & 100 & 103 & 300 & 120 & 55 & 120 & 55 & 120 & 55 & 0.375 & 42 & 0.375 & 36 & 0.375 & 36 \\
\hline S-9 & WTC 1 & 133 & 97 & 100 & 300 & 122 & 55 & 122 & 55 & 122 & 55 & 0.375 & 36 & 0.375 & 42 & 0.375 & 36 \\
\hline $\mathrm{N}-10$ & WTC 1 & 115 & 89 & 92 & 300 & 125 & 55 & 125 & 55 & 125 & 55 & 0.375 & 36 & 0.375 & 42 & 0.375 & $4 z$ \\
\hline C- 40 & WTC 1 & 136 & 98 & 101 & 300 & 121 & 55 & 121 & 60 & 121 & 60 & 0.375 & 42 & 0.375 & 36 & 0.375 & $4 z$ \\
\hline C- 89 & WTC 2 & 215 & 12 & 15 & 300 & 143 & 55 & 145 & 50 & 143 & 50 & 1.375 & 36 & 1.375 & 36 & 1.375 & 36 \\
\hline$N-7$ & WTC 1 & 127 & 97 & 100 & 300 & 121 & 60 & 121 & 55 & 121 & 55 & 0.375 & 42 & 0.375 & 42 & 0.375 & 42 \\
\hline C-92 & WTC 2 & 130 & 93 & 96 & 300 & 123 & $6 \theta$ & 123 & $6 \theta$ & 124 & 60 & 0.375 & 42 & 0.375 & 42 & 0.375 & $4 z$ \\
\hline C-93 & WTC 1 & 339 & 99 & 102 & 300 & 124 & 60 & 121 & 60 & 124 & 60 & 0.375 & 42 & 0.375 & $4 z$ & 0.375 & $4 z$ \\
\hline $\mathrm{K}-1$ & WTC 1 & 209 & 97 & 100 & 300 & 120 & 60 & 120 & 60 & 120 & 60 & 0.375 & 42 & 0.375 & 42 & 0.375 & 42 \\
\hline $\mathrm{K}-2$ & WTC 1 & 236. & 92 & 95 & 300 & 120 & 6 & 120 & 60 & 120 & 60 & 0.375 & 42 & 0.375 & 42 & 0.375 & 42 \\
\hline$N-8$ & WTC 1 & 142 & 97 & 100 & 300 & 121 & 60 & 121 & 60 & 121 & 60 & 0.375 & 42 & 0.375 & 42 & 0.375 & 42 \\
\hline C-48 & WTC 2 & 442 & 91 & 94 & 300 & 120 & 65 & 120 & 65 & 120 & 65 & 0.375 & 45 & 0.375 & 45 & 0.375 & 42 \\
\hline $\mathrm{N}-99$ & WTC 1 & 148 & 99 & 102 & 300 & 120 & 65 & 120 & 65 & 120 & 65 & 0.375 & 45 & 0.375 & 42 & 0.375 & 42 \\
\hline S-14 & WTC 2 & 218 & 91 & 94 & 300 & 120 & 70 & 120 & 65 & 120 & 65 & 0.375 & 46 & 0.375 & 45 & 0.375 & 45. \\
\hline M-28 & WTC 2 & 345 & 98 & 101 & 300 & 120 & 70 & 120 & 70 & 120 & 70 & 0.375 & 45 & 0.375 & 45 & 0.375 & 45 \\
\hline C- 55 & WTC 1 & 209 & 94 & 97 & 300 & 130 & 79 & 120 & 70 & 120 & 79 & 0.375 & 46 & 0.375 & 45 & 0375 & 45 \\
\hline S-10 & WTC 1 & 224 & 92 & 95 & 300 & 120 & 70 & 120 & 70 & 120 & 70 & 0.375 & 50 & 0.375 & 46 & 0.375 & 45. \\
\hline S-1 & WTC 1 & 433 & 79 & 82 & 300 & 123 & 70 & 123 & 70 & 123 & 79 & 04375 & 50 & 0.4375 & 46 & 04375 & 45 \\
\hline$N-1$ & WTC 1 & 218 & 82 & 85 & 300 & +23 & 75 & 123 & 75 & 123 & 70 & 0.4375 & 50 & 0375 & 50 & 0.375 & 50 \\
\hline C-46 & WTC 2 & 157 & 68 & 71 & 300 & 129 & 65 & 128 & 70 & 126 & 80 & 0.625 & 65 & 0.625 & 65 & 0.5625 & 65 \\
\hline $\mathrm{N}-12$ & WTC 1 & 206 & 92 & 95 & 300 & 120 & 75 & 120 & 75 & 120 & 75 & 0.375 & 50 & 0.375 & 50 & 0.375 & 46 \\
\hline C-22 & WTC 1 & 157 & 93 & 96 & 300 & 120 & 80 & 120 & 75 & 120 & 80 & 0.375 & 65 & 0.375 & 60 & 0.375 & 60 \\
\hline C- 25 & WTC 1 & 206 & 89 & 92 & 300 & +20 & 80 & 120 & 8 & 120 & 80 & 0.375 & 55 & 0.375 & 55 & 0.375 & 55 \\
\hline B-1044 & WTC 2 & 409 & 40 & 43 & 400 & 335 & 85 & 335 & 80 & 335 & 85 & 0.9375 & 60 & $\mathrm{n} / \mathrm{a}$ & $\mathrm{n} / \mathrm{a}$ & 0.9375 & 50 \\
\hline M-10a & WTC 2 & 209 & 82 & 85 & 300 & 120 & 85 & 120 & 85 & 120 & 85 & 0.4375 & 60 & 0.375 & 60 & 0.375 & $6 \theta$ \\
\hline$M-10 b$ & WTC 2 & 206 & 83 & 86 & 300 & 120 & 85 & 120 & 85 & 120 & 85 & 0.375 & 60 & 0.375 & 6 & 0.375 & 55 \\
\hline$C-10$ & WTC 1 & 451 & 85 & 88 & 300 & 120 & 85 & 120 & 85 & 120 & 90 & 0.375 & 60 & 0.375 & 60 & 0.375 & 60 \\
\hline B-1043 & WTC 2 & 406 & 40 & 43 & 400 & 334 & 90 & 334 & 90 & 335 & 85 & 0.9375 & 65 & n'a & $\mathrm{n} / \mathrm{a}$ & 0.9375 & 50 \\
\hline C- 24 & WTC 2 & 203 & 74 & 77 & 400 & 325 & 100 & 325 & 100 & 325 & 100 & 0.5624 & 70 & $n^{\prime} a$ & $n / a$ & 0.5625 & 80 \\
\hline$C-13,13 \mathrm{a}$ & WTC 2 & 200 & 90 & 92 & 210 & 120 & 100 & 520 & 100 & 120 & 100 & $n / a$ & n/a & 0.375 & 70 & 0.375 & 70 \\
\hline C-14 & WTC 2 & 300 & 85 & 87 & 210 & 120 & 100 & 5272 & 400 & 122 & 100 & n/a & n/a & 0.375 & 75 & 0375 & 75 \\
\hline
\end{tabular}

a. Columns 1,2 , and 3 are left to right viewed from inside the building.

Note: Strike through indicates section is missing. 
Table 4-2. Strength/gauge combinations of perimeter columns recovered by NIST.

\begin{tabular}{|c|c|c|}
\hline $\begin{array}{l}\text { Flange } F_{y} \\
\text { (ksi) }\end{array}$ & $\begin{array}{l}\text { Flange Gauge } \\
\text { (in.) }\end{array}$ & $\begin{array}{c}\text { Number of Columns Recovered and } \\
\text { Identified by NIST }\end{array}$ \\
\hline 45 & 1.75 & 1 \\
\hline 50 & 0.5 & 2 \\
\hline 50 & 0.5625 & 2 \\
\hline 50 & 1.0625 & 2 \\
\hline 50 & 1.8105 & 1 \\
\hline 50 & 2.0625 & 1 \\
\hline 50 & 2.125 & 1 \\
\hline 50 & 2.25 & 1 \\
\hline 50 & 2.5 & 1 \\
\hline 50 & 2.625 & 1 \\
\hline 55 & 0.25 & 12 \\
\hline 55 & 0.3125 & 5 \\
\hline 55 & 0.375 & 6 \\
\hline 55 & 0.4375 & 3 \\
\hline 55 & 0.5625 & 3 \\
\hline 55 & 1.375 & 1 \\
\hline 55 & 1.6875 & 1 \\
\hline 60 & 0.25 & 5 \\
\hline 60 & 0.3125 & 6 \\
\hline 60 & 0.375 & 1 \\
\hline 60 & 0.5 & 1 \\
\hline 65 & 0.25 & 7 \\
\hline 65 & 0.375 & 1 \\
\hline 65 & 0.8125 & 1 \\
\hline 70 & 0.25 & 7 \\
\hline 70 & 0.4375 & 2 \\
\hline 70 & 0.75 & 1 \\
\hline 75 & 0.25 & 3 \\
\hline 75 & 0.4375 & 2 \\
\hline 80 & 0.25 & 3 \\
\hline 80 & 0.625 & 1 \\
\hline 80 & 1.1875 & 1 \\
\hline $85-100$ & 0.25 & 12 \\
\hline $85-100$ & 0.5625 & 3 \\
\hline $85-100$ & 1.125 & 2 \\
\hline $85-100$ & 1.1875 & 3 \\
\hline
\end{tabular}


Table 4-3. Strength/gauge combinations of spandrels recovered by NIST.

\begin{tabular}{|c|c|c|}
\hline $\begin{array}{c}\text { Spandrel } F_{y} \\
(\mathrm{ksi})\end{array}$ & Spandrel Gauge (in.) & $\begin{array}{c}\text { Number of Spandrels Recovered by } \\
\text { NIST }\end{array}$ \\
\hline 36 & \begin{tabular}{|c|}
$3 / 8$ \\
\end{tabular} & 16 \\
\hline 36 & $9 / 16$ & 3 \\
\hline 36 & $11 / 4$ & 3 \\
\hline 36 & $13 / 8$ & 3 \\
\hline 42 & $3 / 8$ & 24 \\
\hline 45 & $3 / 8$ & 7 \\
\hline 46 & $3 / 8$ & 4 \\
\hline 50 & $3 / 8$ & 5 \\
\hline 50 & $7 / 16$ & 2 \\
\hline 50 & $15 / 16$ & 2 \\
\hline 55 & $3 / 8$ & 2 \\
\hline 60 & $3 / 8$ & 6 \\
\hline 60 & $15 / 16$ & 1 \\
\hline 65 & $3 / 8$ & 1 \\
\hline 65 & $9 / 16$ & 1 \\
\hline 65 & $5 / 8$ & 2 \\
\hline 65 & $15 / 16$ & 1 \\
\hline 70 & $3 / 8$ & 2 \\
\hline 75 & $3 / 8$ & 1 \\
\hline 80 & $9 / 16$ & 1 \\
\hline
\end{tabular}


This page intentionally left blank. 


\section{Chapter 5 \\ SUMMARY}

The National Institute of Standards and Technology has 236 samples from the World Trade Center (WTC) buildings, the majority belonging to WTC 1 and WTC 2. These samples represent roughly a half percent of the 200,000 tons of structural steel used in the construction of the two towers. The collection of steel from the WTC towers is sufficient for determining the quality of the stecl and for dctermining mechanical properties as input to models of building performancc as sufficient represcntative samples exist for all 12 grades of exterior panel material, 2 grades of the core column material (that rcpresents 99 percent, by total number, of columns), and both grades for the floor truss material. 
This page intentionally left blank. 


\section{Chapter 6 \\ REFERENCES}

Astaneh-Asl, A. 2002. World Trade Center Post-Disaster Reconnaisance and Perishable Structural Engineering Data Collection, Final Report to National Science Foundation, UCB/CEE-Steel2002/04. University of California, Department of Civil and Environmental Engineering, Berkeley, CA.

McAllister, T., ed. 2002. World Trade Center Building Performance Study: Data Collection, Preliminary Observations, and Recommendations. FEMA 403. Federal Emergency Management Agency. Washington, DC, May. 
This page intentionally left blank. 


\section{A.1 DATABASE OF RECOVERED STEEL}

Table A-1. List of all WTC steel elements recovered for NIST investigation.

\begin{tabular}{|c|c|c|c|c|c|c|c|c|}
\hline $\begin{array}{l}\text { In FEMA } \\
\text { report? }\end{array}$ & NIST Name & Type & Brief Description & Markings & Bldg & Column & Floors & Location \\
\hline$Y$ & AA & c & 2 full columns, thick walled & & & & & $\mathrm{PL}$ \\
\hline$Y(N S F)$ & ASCE-2 & c & 1 full column & B330: $40-43$ & WTC 2 & 330 & $40-43$ & $P L$ \\
\hline \multirow[t]{13}{*}{$Y(N S F)$} & ASCE-3. & c & 1 column, bottom $1 / 3 r d$ of left column & & & & & PL \\
\hline & B-1011 & PB & Heavy rectangular column & 508A: $51-54$ & WTC 1 & 508 & 51- & JFKJPL \\
\hline & B-1022 & $w$ & Thick wide flange with severe bend & & & & & 205 \\
\hline & B-1024. & c & 3 full columns & B154: $21-24$ & WTC 2 & 154 & $21-24$ & JFK \\
\hline & E-1043 & c & Mechanical floor, 3 full columns & B406: $40-43$ & WTC 2 & 406 & $40-43$ & JFKUPL \\
\hline & E-1044 & c & Mechanical floor, 3 full columns & E.409: $40-43$ & WTC 2 & 409 & $40-43$ & JFKJPL \\
\hline & $\mathrm{B}-1044 \cdot 1$ & 0 & $\begin{array}{l}\text { Piece of crushed metal decking assoc } \\
\text { with B-1044 }\end{array}$ & & & & & 202 \\
\hline & B.1075 & W & Wide flange & & & & & 205 \\
\hline & E-2150 & 0 & Pieces of aluminum sheathing & & & & & 202 \\
\hline & B-5004 & BT & Bowtie section & & & & & JFKUPL \\
\hline & $B-5007$ & BT & Bowtie section & & & & & JFK'PL \\
\hline & B-6152-1 & PRE & Heavy rectangular column & 803A: $15 \cdot 18$ & WTC 1 & 803 & $15-19$ & $P L$ \\
\hline & E- $6152-2$ & $\mathrm{RB}$ & Heary rectangular column & $504 A: 33-36$ & WTC 1 & 504 & $33-36$ & $P L$ \\
\hline Y & $\mathrm{BB}$ & c & Single, thick column & & & & & 205 \\
\hline Y & c-10 & c & Full panel & 451: $85-88$ & WTC 1 & 451 & $85-88$ & $\mathrm{PL}$ \\
\hline Y & $c-11$ & c & 2 columns, upper $2 / 3 \mathrm{rds}$ & & & & & 205 \\
\hline Y & $c-13$ or $S-11$ & $\mathrm{Cc}$ & $\begin{array}{l}\text { Single rectangular column with large } \\
\text { spandrels }\end{array}$ & B200: $90-92$ & WTC 2 & 200 & $90-92$ & $P L$ \\
\hline Y & C-13a or $5-19$ & c & Partial of single column $\ldots \ldots$ & B200: $90-92$ & WTC 2 & 200 & $90-92$ & $P L$ \\
\hline Y & C-14 or $S-18$ & C & 1 column, lower $1 / 3 r d$ & B300: $85-87$ & WTC 2 & 300 & $85-87$ & B. \\
\hline Y & $c \cdot 15 \ldots \ldots$ & c & Partial of single column & & & & & 205 \\
\hline Y & $c-16$ & c & 1 column, upper $1 / 3$ rd & & & & & 205 \\
\hline Y & C-16a & c & Fell off during moving of $C-16$ & & & & & 205 \\
\hline \multirow[t]{2}{*}{ Y } & $c-18$ & c & 3 columns, bottom $2 / 3$ rds & E:230: $93-96$ & WTC 2 & 230 & $93-96$ & $P L$ \\
\hline & C-18 Associated & $\mathrm{B}$ & One washer and nut & & & & & Lab \\
\hline$Y$ & $C .22$ & c & 3 columns, lower $1 / 2$, mangled & A157: $93-96$ & WTC 1 & 157 & $93-96$ & $P L$ \\
\hline Y & $c-24$ & c & $\begin{array}{l}3 \text { columns, upper } 1 / 2 \text {, columns } \\
\text { change dimensions }\end{array}$ & B203: $74-77$ & NTC 2 & 203 & $74-77$ & 205 \\
\hline Y & C- 25 & c & 1 column, lower $1 / 2$ & A206: 89-92 & WTC 1 & 206 & $89-92$ & $P L$ \\
\hline$Y$ & $c-26$ & w & Three connected wide flanges & $604 \& 605$ (107) 64 Fy 50 & & & & $P L$ \\
\hline Y & $c-28$ & $c$ & 1 column of unknown location. & & & & & 205 \\
\hline Y & C. $28 \mathrm{~B}$ & $\mathrm{CC}$ & Corner column, in 2 pieces & & & & & 205 \\
\hline$y$ & c.29 & $W$ & Wide flange & & & & & 205 \\
\hline Y & $C-30$ or $S-12$ & $W$ & Wide flange & $1008 \mathrm{~B} \times 04-10 x$ & WTC 2 & 1008 & $104-106$ & $P L$ \\
\hline Y & $\mathrm{C}-31$ or $\mathrm{S}-7$ & W & Wide flange & $676 \quad 35$ & & & & 205 \\
\hline Y & c.32 & c & 1 column, upper $1 / 3 r d$ & $\cdots$ & & & & 236 \\
\hline Y & c-35 & W & Wide flange & & & & & 205 \\
\hline$Y$ & $C-40$ & c & 2 columns, lower $2 / 3$ rds & A136: 98-101 & MTC 1 & 136 & $98-101$ & $P L$ \\
\hline
\end{tabular}


Table A-1. List of all WTC steel elements recovered for NIST investigation (continued).

In FEMA
report? NISTName Type Brief Description $\quad$ Markings Bldg Column Floors Location $\frac{\text { report? }}{Y^{n}} \quad C-41$

Y $\quad C-42$

Y C -43

C 1 column, lower $2 / 3 \mathrm{rds}$

$W$ Wide flange

$\begin{array}{ll}Y & C-43 \\ Y & C-44 \\ Y & C-45 \\ Y & C-46 \\ Y & C-47 \\ Y & C-48 \text { or } S-5 \\ Y & C-49 \text { or } S-6 \\ Y & C-51 \\ Y & C-52 \\ Y & C-53 \\ Y & C-538\end{array}$

C. 1 column, lower $1 / 2$.

Wide flange, FEMA reported possible

W core columns

$59 S 563$

Wide flange, FEMA reponted possible

core columns

1652563

PL

C. Nearly 3 full columns

B157: 68-71

3 columns, upper $1 / 2$

Nearly 2 full columns

B442, $91-94$

MTC $2 \quad 157 \quad 68-71$

PL

partion of 1 column

$\begin{array}{llll}\text { MTC } 2 & 442 & 91-94 & 205\end{array}$

2 columns, upper $1 / 2$

1 column, upper 2 Brds

Floor truss

Floor truss

1 column,small piece with extended

$\frac{Y}{Y}-\frac{C-54}{C-55}$

outer web

C -55

C- 61

C- 62

C. 64

C. 65 or $\$-8$

C-66 or 5-17

C- -67

C- 68

c- 69

C-70

C-71

c- $72 \mathrm{~b}$

c-73

C.74

1 column, lower $1 / 3$ rd

Wide flange, S-shaped

Wide flange

Wide flange

1 column with a lot missing

Wide flange

Wide flange

1 column, rest unknown

1 column, upper $1 / 2$

Wide flange

Wide flange

Wide flange

Wide flange

1 column, upper $1 / 2$

236

205

205

PL

PL

Wide flange

209. 94-97

$193 \quad 5157$

$150 \mathrm{~S} \quad 69$

224 (S) <48>

205

Portion of 1 column and spandrel, rest

unknown

904A (B6-69) <52>

WTC 1

$\mathrm{PL}$

PL

PL.

PL

205

$\mathrm{PL}$

205

205

205

205

205

PL

205

205

205

Y $\quad$ C-75

Y $\quad$ C.76

$Y \quad C-77$

Y $\quad$ C-78

Y $\quad C .79$

Wide flange

236

2 columns from different panels

att ached at spandrel, 1/3rd of each

205

Wide flange

205

Rectangular column, FEMA reported

possible core column

101A.81-85-87-92 WTC 1

205

Wide flange, FEMA reported possible

core columns

52

$\mathrm{PL}$

$Y \quad c-80$

W

Wide flange

603A. $92-95<51\rangle \quad$ WTC $1 \quad 603 \quad 92-95 \quad \mathrm{FL}$

Wide flange

Heary rectangular column, FEMA

reported as possible core column

No ID, similar to other

core column

$Y$ (NSF) C-84

$Y$ (NSF) $\quad C-85$

1 full column

Wide flange

Thick Wide flange

Y C-88a

Built-up box column, FEMA reported

possible core column

$\ldots \ldots+\ldots$

Built-up box column, welded to C-88a

C-88b

Broke off C-88

$801 \mathrm{E} 77-80$

WTC 2801

$80-83$

205

Y (NSF) C-89

2 full columns

B 215: $12-15$ MTC 2 215 $12-15$

MTC $2 \quad 801 \quad 77-80$

PL

PL

PL

c

PL 
Table A-1. List of all WTC steel elements recovered for NIST investigation (continued). $\frac{\text { In FEMA }}{\text { repor? }}$ NIST Name Type Brief Description

Markings

Heawy rectarigular column, FEMA

Y (NSF) C-90

Y C-9

Y $\quad$ C.92

Y C.93

C-94

C.95

C- 96

C. 97

C. 98

C-99

C-100

C-101

C-102

C-103

C-104

C-105

C. 106

C- 107

C- 108

C- 109

C- 110

C-111

C-112

C-113

C-114

C-115

C- 116

C-117

C- 118

C-119A

C-119B

C. -120

C-121

C- 122

C- 123

C- 124

C. -125

C- 126

C- 128

C-129

C. 130

C-131

C- 132

C-133

C- 134

c-135

C-137a

$c-137 b$

$\mathrm{C}-137 \mathrm{c}$

C-137d

c- $137 f$

reported as possible care column

Channel

Partial of sirigle column

Partial of single column

May be some type of brace,

rectangular box construction

Channel

Channel

Channel

Channel

Channel

Possible angle from a floor truss

thinner

Partial of single column

Square-tube construction

Possible angle from a floor truss

Channel

Small piece of floor truss

Channel

Three sheared bolts

Single bolt sheared

Bolt and nut

Bolt and washer

Single bolt sheared

Two sheared bolts with washers

Sheared bolt with nut

Pig-tailed piece from floor truss

Damper

3 columns, lower $1 / 3$

Channel

101-104

Square-tube construction

Square-tube construction

Square-tube construction

Square-tube construction

Piece of floor truss

Small Wide flange

Channel

Channel

Mide flange

Channel

Channel

Wide Flange

Small portion of floor truss with

cement

Piece of floor truss

1 column, bottom $1 /$ Brd of unknown

location

Channel

May be some type of brace,

rectangular box construction

Piece of floor truss

Piece of floor truss

Piece of floor truss

Piece of floor truss

$\begin{array}{ccccc}701 \mathrm{~B} 12.15 & \text { WTC 2 } & 701 & 12.15 & \mathrm{PL} \\ & & & & 236 \\ \text { E13x:93-96 } & \text { WTC 2 } & 130 & 93.96 & \mathrm{PL} \\ 339.99-102 & \text { WTC 1 } & 339 & 99.102 & \mathrm{PL}\end{array}$

$\begin{array}{llll}78 A & 10 & 27 & 50\end{array}$

$\mathrm{P}$

236

236

236

236

236

PL

PL

205

PL

PL

236

202

236

Lab

Lab

Lab

Lab

Lab

Lab

Lab

Lab

Lab

PL

236

PL

$P L$

PL

$P L$

PL

205

236

236

205

Piece of floor truss
B

236

205

202

PL

205

236

PL

PL

PL

PL

PL

PL 
Table A-1. List of all WTC steel elements recovered for NIST investigation (continued).

\begin{tabular}{|c|c|c|c|c|c|c|c|c|}
\hline $\begin{array}{l}\text { In FEMA } \\
\text { report? }\end{array}$ & NIST Name & Type & Brief Description & Mlarkings & Bldg & Column & Floors & Location \\
\hline & $C-138$ & $W$ & Small wide flange & & & & & 205 \\
\hline & $C-139$ & $\mathrm{Ch}$ & Channel & & & & & 236 \\
\hline & $C-140$ & J & Piece of angle & & & & & $\mathrm{PL}$ \\
\hline & $C-141$ & $\mathrm{Ch}$ & Channel & & & & & 236 \\
\hline & C-142. & $w$ & Wide flange & & & & & 205 \\
\hline & $C-143$ & $\mathrm{Ch}$ & Channel & & & & & 236 \\
\hline & $C-144$ & $\mathrm{Ch}$ & Channel & & & & & 236 \\
\hline & $C-145$ & $\mathrm{Ch}$ & Channel & & & & & 236 \\
\hline & $c-146 a$ & 0 & Mangled ball of steel and concrete. & & & & & 202 \\
\hline & $C-146 b$ & J & Piece of floor truss & & & & & PL \\
\hline & $C-147$ & $\mathrm{Ch}$ & Channel & & & & & 236 \\
\hline & C- 148 & $\mathrm{Ch}$ & Channel & & & & & 236 \\
\hline & C-149 & J & Piece of floor truss & & & & & PL \\
\hline & $C-150$ & $W$ & Wide flange & & & & & 205 \\
\hline & $C-151$ & $\mathrm{~d}$ & Piece of floor truss & & & & & $P L$ \\
\hline & C-152 & $\mathrm{Ch}$ & Channel & & & & & 236 \\
\hline & $C-153$ & $\mathrm{Ch}$ & Channel & & & & & 236 \\
\hline & $C-154$ & $\mathrm{RE}$ & Thin rectangular beam with supports & $825: 107-108 \quad 52$ & & & & $\mathrm{PL}$ \\
\hline & $C-155$ & W & Wide fiange & $904 A .83-86$ & NTC 1 & 904 & $83-86$ & PL \\
\hline & $C-156$ & 0 & Square-tube construction & & & & & $\mathrm{PL}$ \\
\hline Y & $\mathrm{CC}$ & c & 2 fuil columns & 124: $73-70$ & WTC 1 & 124 & $70-73$ & $P L$ \\
\hline Y & $\mathrm{OD}$ & c & $\begin{array}{l}1 \text { Column, spans } 1 \text { floor arid has end } \\
\text { plates on both ends }\end{array}$ & & & & & 205 \\
\hline Y & FF & $\mathrm{C}$ & Single, thick column & & & & & 205 \\
\hline & GZ-1 & $\mathrm{Cn} 5$ & $\begin{array}{l}\text { Received from D. Sharp, caupon from } \\
\text { Bidg } \ldots\end{array}$ & & & & & Lab \\
\hline & $G Z-2$ & $\mathrm{Cn} 5$ & $\begin{array}{l}\text { Received from D. Sharp, coupon from } \\
\text { Bldg } \$ 5\end{array}$ & & & & & Lab \\
\hline & GZ-3 & $\mathrm{Cn} 5$ & $\begin{array}{l}\text { Peceived from D. Sharp, coupon from } \\
\text { Bidg } 55\end{array}$ & & & & & Lab \\
\hline & GZ-4 & Cn5 & $\begin{array}{l}\text { Recened from D. Sharp, coupon from } \\
\text { Bidg }\end{array}$ & & & & & Lab \\
\hline & $G Z-5$ & $\mathrm{Cn} 5$ & $\begin{array}{l}\text { Received from D. Sharp, coupon from } \\
\text { Bldg } \$ 5\end{array}$ & & & & & Lab \\
\hline & GZ-6 & Cn5 & 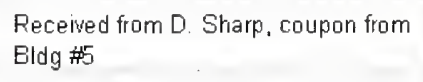 & & & & & Lab \\
\hline & GZ-7 & $\mathrm{Cn} 5$ & $\begin{array}{l}\text { Received from D. Sharp, coupori from } \\
\text { Bldg } \$ 5\end{array}$ & & & & & Lab \\
\hline Y & $\mathrm{HH}$ or $\mathrm{S}-2$ & $W$ & $\begin{array}{l}\text { Wide flange, FEMA, reported possibie } \\
\text { core column }\end{array}$ & $605 A \quad 98-101$ & WTC 1 & 605 & $98-101$ & PL \\
\hline Y & $K-1$ or $K-13$ & c & 3 columns, lower $1 / 3 r d$ & $209.97-100$ & WTC 1 & 209 & $97-100$ & 202 \\
\hline Y & $K-2$ or $K-40$ & C & 1 column, lower $2 / 3 r d s$ & $23692-95$ & WTC 1 & 236 & $92-95$ & $\mathrm{PL}$ \\
\hline Y & $K-10$ & $\mathrm{Cn}$ & $\begin{array}{l}\text { Flange coupon received from Gross, } \\
\text { July } 29,2002\end{array}$ & & & & & Lab \\
\hline Y & $k-11$ & $\mathrm{Cn}$ & $\begin{array}{l}\text { Flange coupon received from Gross, } \\
\text { July } 29,2002\end{array}$ & & & & & Lab \\
\hline$Y$ & $k-12$ & $\mathrm{Cn}_{n}$ & $\begin{array}{l}\text { Flange coupon received from Gross, } \\
\text { July } 29,2002\end{array}$ & & & & & Lab \\
\hline Y & $k-13$ & $\mathrm{Cn}$ & $\begin{array}{l}\text { Flange coupon received from Gross, } \\
\text { July } 29,2002\end{array}$ & & & & & Lab \\
\hline
\end{tabular}


Table A-1. List of all WTC steel elements recovered for NIST investigation (continued).

\begin{tabular}{|c|c|c|c|c|c|c|c|c|}
\hline$\frac{\text { In FEMA }}{\text { report? }}$ & NIST Name & Type & Brief Description & Markings & Bldg & Culumin & Floors & Locatior \\
\hline$Y$ & $K-14$ & $\mathrm{Cn}$ & $\begin{array}{l}\text { Flange coupon received from Gross, } \\
\text { July } 29,2002\end{array}$ & & & & & Lat \\
\hline$Y$ & $K-15$ & $\mathrm{Cn}$ & $\begin{array}{l}\text { Flange coupon received from Gross, } \\
\text { July } 29,2002\end{array}$ & & & & & Lat \\
\hline \multirow[t]{2}{*}{$Y$} & $K-16$ & C & $\begin{array}{l}1 \text { full column, thick, looks very } \\
\text { corroded }\end{array}$ & & & & & FL \\
\hline & $k-16 a$ & c & Fell off of $K-16$ while moving & & & & & FL \\
\hline$Y$ & $K-18$ & $\mathrm{Cn}$ & $\begin{array}{l}\text { Flange coupon received from Gross, } \\
\text { July } 29,2002\end{array}$ & & & & & Lat \\
\hline$Y$ & $K-19 a$ & $C_{n}$ & $\begin{array}{l}\text { Flange coupon received from Gross, } \\
\text { July } 29,2002\end{array}$ & & & & & Lat \\
\hline Y & $k-19 b$ & $\mathrm{Cn}_{\mathrm{n}}$ & $\begin{array}{l}\text { Flange coupon received fram Gross, } \\
\text { July } 29,2002\end{array}$ & & & & & Lat \\
\hline$Y$ & $K-50 a$ & 0 & $\begin{array}{l}\text { Rectangular slab of steel with tolts, } \\
\text { received from } D \text {. Sharp, SEAONY }\end{array}$ & & & & & Lab \\
\hline Y & $K-50 b$ & $\mathrm{O}$ & $\begin{array}{l}\text { Rectangular slab of steel with tolts, } \\
\text { received from } D \text {. Sharp. SEAoNY }\end{array}$ & & & & & Lab \\
\hline$Y$ & $k-50 c$ & 0 & $\begin{array}{l}\text { Rectangular slab of steel with bolts, } \\
\text { recened from } D \text {. Sharp. SEAONY }\end{array}$ & & & & & Lab \\
\hline$Y$ & $M-2$ & c & $--\ldots$ & $-9<63\rangle$ & WTC 1 & 130 & $96-99$ & $P L$ \\
\hline Y & $M-4$ or M-5 & $\mathrm{c}$ & 3 colurnns, upper $2 / 3 r d s$ & & & & & 205 \\
\hline Y & $\mathrm{M}-10 \mathrm{a}$ & c & 3 columns, unknown location & B209: $82-85$ & WTC 2 & 206 & $82-85$ & $P L$ \\
\hline $\mathrm{Y}$ & $M-10 b$ & C & 3 columns, lower $1 / 2$ & E206: 83-86 & WTC 2 & 206 & $83-86$ & $P L$ \\
\hline Y & $M-11$ & $w$ & Wide flange & & & & & 205 \\
\hline \multirow[t]{24}{*}{ Y } & $M-17$ & W & $\begin{array}{l}\text { Wide flange or I-beam, } 1 \text { ' flange, } 2 \text { ' } \\
\text { web, } 50-60 \text { ' long }\end{array}$ & 163 (9) 62 & & & & 205 \\
\hline & $M-17 a$ & 0 & Fell off of M-17 while moving & & & & & 202 \\
\hline & $M-18$ & $\mathrm{RB}$ & Large box beam, 19" $\times 21 " \times 175^{\prime}$ long & & & & & 205 \\
\hline & $M-19$ & C & 2 columns, upper $1 / 3 r d$ & & & & & 205 \\
\hline & $M-20$ & c & 2 columns, lower $1 / 3 r d$ & A121: 99-102 & WTC 1 & 121 & $99-102$ & $P L$ \\
\hline & $M-22$ & $\mathrm{RB}$ & $\begin{array}{l}\text { Large box beam, } 19^{\prime \prime} \times 26.5^{\prime \prime} \times 9.5^{\circ} \\
\text { long. }\end{array}$ & & & & & 205 \\
\hline & $M-23$ & W & Possibly part of Wide flange or l-beam & F 2010 & & & & $P L$ \\
\hline & $M-24$ & $\mathrm{Ch}$ & Channel ................. & & & & & 236 \\
\hline & $M-25$ & $\mathrm{~J}$ & Small piece of floor truss & & & & & 202 \\
\hline & $M-26$ & C & 3 full columns & A.130: $90-93$ & WTC 1 & 130 & $90-93$ & $P L$ \\
\hline & $M-26$ associated & $\mathrm{B}$ & 8 bolts and a nut & & & & & Lab \\
\hline & $M-27$ & c & 2 columns, lower $3 / 4$ ths & A130: 93-96 & WTC 1 & 130 & $93-96$ & 202 \\
\hline & $M-28$ & c & 3 columns, lower $1 / 4$ th & $83459 x-1 x x$ & WTC 2 & 345 & $98-101$ & $P L$ \\
\hline & $M-29$ & 0 & $5 \mathrm{ft}$ piece of strapping & & & & & 202 \\
\hline & $M-30$ & c & 2 columns, lower $1 / 3$ rd & $-33.94-97$ & NTC 1 & 133 & $94-97$ & 202 \\
\hline & M-30 associated & $\mathrm{O}$ & $\begin{array}{l}\text { Pieces of glass, plexiglass, other } \\
\text { rutble }\end{array}$ & & & & & Lab \\
\hline & $M-31 \ldots$ & $J$ & Pieces of floor truss & & & & & Lab \\
\hline & $M-32$ & $J$ & Pieces of floor truss & & & & & Lab \\
\hline & $M-33$ & $W$ & Wide flange & & & & & 205 \\
\hline & $M-34$ & $\mathrm{Ch}$ & Channel & & & & & $\mathrm{E}$ \\
\hline & $M-35$ & $C C$ & Corner column & & - & & & 205 \\
\hline & $M-36$ & \lrcorner & Thick angle & & & & & $P L$ \\
\hline & $M-37$ & $W$ & Wide flange & $130(8 ?-92)<50>$ & & & & 205 \\
\hline & $M-38$ & W & Wide flange & Fy 42 & & & & $P L$ \\
\hline
\end{tabular}


Table A-1. List of all WTC steel elements recovered for NIST investigation (continued).

\begin{tabular}{|c|c|c|c|c|c|c|c|c|}
\hline$\frac{\text { In FEMA }}{\text { report? }}$ & NIST Name & Type & Brief Description & Markings & Bldg & Column & Floors & Location \\
\hline$y-1$ & $N-1$ & $c$ & 2 full columns & $2 \_8: 82-85$ & MTC 1 & 218 & $82-85$ & $\mathrm{PL}$ \\
\hline$Y$ & $N-3$ & c & 1 column, upper $1 / 2$ & & & & & 236 \\
\hline Y & $N-4$ & C & 1 column, middle $1 / 3 r d$ & & & & & 236 \\
\hline$Y$ & $N-5$ & 0 & Part of spandrel plate with bolts & & & & & $\mathrm{PL}$ \\
\hline$Y$ & $N-6$ & c & 1 column, length of spandrel, crushed & & & & & 236 \\
\hline$Y($ as $M-3)$ & $N-7$ or $M-3$ & C & 3 full columns & $127: 97-100$ & MTC 1 & 127 & $97-100$ & $\mathrm{PL}$ \\
\hline$Y($ as $M-7)$ & $N-8$ or $M 7$ & C & Full pranel & A142: $97-100$ & WTC 1 & 142 & $97-100$ & $P L$ \\
\hline$Y$ (as $M-8)$ & $N-9$ or $M-8$ & c & $\begin{array}{l}\text { Almost full pariel, missing lower } 1 / 3 \text { rd } \\
\text { of } 1 \text { column }\end{array}$ & A.154: $101-104$ & WTC 1 & 154 & $101-104$ & $\mathrm{PL}$ \\
\hline 15) । & $\mathrm{N}-10$ or $\mathrm{M}-15$ & c & 2 columns, lower $2 / 3 r d s$ & A115: 89-92 & MTC 1 & 115 & $89-92$ & $P L$ \\
\hline$Y(\operatorname{as} M-9)$ & $\mathrm{N}-11$ or $\mathrm{M}-9$ & C & 3 columns, upper $2 / 3 r d s$ & & & & & 205 \\
\hline 13) & $\mathrm{N}-12$ or $\mathrm{M}-13$ & C & 2 full columns & -06: 92-95 & MTC 1 & 206 & $92-95$ & $P L$ \\
\hline 14) & $\mathrm{N}-13$ or $\mathrm{M}-14$ & c & 3 columns, lower 1 SIrd & A.130: $99-102$ & NTC 1 & 130 & $99-102$ & $B$ \\
\hline \multirow[t]{2}{*}{$\begin{array}{c}Y \text { (as M- } \\
16)\end{array}$} & $N-99$ or $M-16$ & c & $\begin{array}{l}\text { A.lmost full panel, missing lower } 1 \text { Brd } \\
\text { of } 1 \text { column }\end{array}$ & A148: $99-102$ & WTC 1 & 148 & $99-102$ & $P L$ \\
\hline & $N-101$ or $M-21$ & C & 3 full columns & A133: $100-103$ & MTC 1 & 133 & $100-103$ & $\mathrm{PL}$ \\
\hline$Y($ as $C-19)$ & $N-N$ or $C-19$ & c & 1 column, lower $1 / 2$ & & & & & 205 \\
\hline$Y(a s E E)$ & S-1 or EE & c & 2 columns, lower $1 / 3 r d$ & A433: $79-82$ & WTC 1 & 433 & $79-82$ & $P L$ \\
\hline$Y($ as $C-50)$ & $S-3$ or $C-50$ & c & 1 column, unknown $1 / 2$ & & & & & 205 \\
\hline$Y$ (as $C-63)$ & $S-9$ or $C-63$ & c & Full panel & A133: $97-100$ & WTC 1 & 133 & $97-100$ & $\mathrm{PL}$ \\
\hline$Y(\operatorname{asc}-17)$ & $\mathrm{S}-10$ or $\mathrm{C}-17$ & C & 2 columns, lower $1 / 2$ & 224. $92-95$ & WTC 1 & 224 & $92-95$ & $\mathrm{PL}$ \\
\hline \multirow[t]{2}{*}{$Y(a s c-20)$} & $S-14$ or $C-20$ & c & Full panel & E218: 91-94 & WTC 2 & 218 & $91-94$ & $\mathrm{PL}$ \\
\hline & $S M-2$ & W & I-beam & & & & & 205 \\
\hline \multirow[t]{4}{*}{$Y(\operatorname{as~} N-2)$} & $\mathrm{T}-1$ or $\mathrm{N}-2$ & $J$ & Floor truss material & & & & & 202 \\
\hline & U-6 & c & 3 columns, upper $1 / 4$ & & & & & 236 \\
\hline & U-15 & c & Partial of single column & & & & & 205 \\
\hline & $\mathrm{U}-25$ & 0 & Unknown Wide flange with concrete & $<$ North $>84-155$ AS DW 2 & & & & 205 \\
\hline Y & $W-14 A$ or $A$ & W & Heary Wide flange & & & & & 205 \\
\hline Y & $W-14 \mathrm{~B}$ & $W$ & Heavy Wide flange & & & & & PL \\
\hline
\end{tabular}

NSF: Pieces contributed by A Asteneh salvaged under NSF contract

Key: 202, Bldg. 202, high bay; 205, Bldg. 205, parking lot; 236, Bldg. 236, parking lot; B, bolt; BT, bowtie section of exterior wall; $\mathrm{C}$, flat wall, exterior column panel section; $\mathrm{CC}$, corner panel section of exterior wall; $\mathrm{Ch}$, channel; $\mathrm{Cn}$, coupon of exterior column; Cn5, coupon from WTC 5; H, hanger; J, floor truss; NSF, pieces contributed by A. Asteneh salvaged under NSF contract; O, other; RB, rectangular, built-up box column; W, wide flange section; Lab, Bldg. 223, Rm B253; JFK. Hanger 17, JFK Airport; JFK/PL, Main piece at JFK, portion at NIST. PL, Bldg. 202, parking lot; 
Table A-2. List of identified exterior panel sections.

\begin{tabular}{|c|c|c|c|c|c|c|c|c|}
\hline In FEMA repori? & NIST Name & Type & Brief Description & \multirow{2}{*}{\multicolumn{2}{|c|}{$\begin{array}{l}\text { Markings } \\
\text { E330: } 40-43\end{array}$}} & \multirow{2}{*}{$\begin{array}{l}\text { Bldg } \\
\text { WTC } 2\end{array}$} & \multirow{2}{*}{$\frac{\text { Column }}{330}$} & \multirow{2}{*}{$\frac{\text { Floors }}{40.43}$} \\
\hline \multirow[t]{4}{*}{$Y(N S F)$} & ASCE-2 & C & 1 full column & & & & & \\
\hline & B-1024 & c & 3 full columns & B154. & $21-24$ & WTC 2 & 154 & 21.24 \\
\hline & B-1043 & c & Mechanical floor, 3 full columns & E406 & $40-43$ & WTC 2 & 406 & $40-43$ \\
\hline & B-1044 & C & Mechanical floor, 3 full columns & $\mathrm{B} 409$ & $40-43$ & MTC 2 & 409 & $40-43$ \\
\hline Y & C-10 & c & Full panel & 451: & 85.88 & WTC 1 & 451 & $85-88$ \\
\hline Y & C-13 or S-11 & $\mathrm{CC}$ & Single rectangular column with large spandrels & $\mathrm{B} 200$ & $90-92$ & MTC 2 & 200 & 90.92 \\
\hline Y & $C-13 a$ or $S-19$ & C & Partial of single column & B200: & $90-92$ & MTC 2 & 200 & 90.92 \\
\hline$Y$ & C. 14 or $S-18$ & c & 1 column, lower $1 / 3$ rd & $\mathrm{B} 300$ & : $85-87$ & WTC 2 & 300 & $85-87$ \\
\hline$Y$ & $C-18$ & c & 3 columns, bottom $2 / 3$ rds & $\mathrm{B} 230$ & : $93-96$ & WTC 2 & 230 & $93-96$ \\
\hline Y & C- 22 & C & 3 columns, lower $1 / 2$, mangled & A157 & :93-96 & MTC 1 & 157 & $93-96$ \\
\hline Y & C-24 & C & 3 columns, upper $1 / 2$, columns change dimensions & $\mathrm{B} 203$ & $74-77$ & MTC 2 & 203 & $74-77$ \\
\hline Y & C. 25 & c & 1 column, lower $1 / 2$ & A206 & $89-92$ & WTC 1 & 206 & $89-92$ \\
\hline Y & C-40 & C & 2 columns, lower $2 / 3 r d s$. & A136: & $98-101$ & WTC 1 & 136 & $98-101$ \\
\hline Y & C-46 & C & Nearly 3 full columns & $\mathrm{B} 157$ & : $68-71$ & WTC 2 & 157 & $68-71$ \\
\hline Y & C. 46 or $5-5$ & C & Nearly 2 full columns. & $\mathrm{B} 442$ & 91.94 & MTC 2 & 442 & $91 \cdot 94$ \\
\hline$Y$ & C. -55 & c & 1 column, lower $1 / 3 r d$ & 209 & $94-97$ & WT 1 & 209 & $94-97$ \\
\hline$Y(N S F)$ & C-89 & c & 2 füll columns & B215: & $12-15$ & WTC 2 & 215 & $12-15$ \\
\hline Y & C-92 & c & Partial of single column & $B 13 x$ & $93-96$ & MTC 2 & 130 & 93.96 \\
\hline$Y$ & C-93 & c & Fartial of single column & 339 & $99-102$ & MTC 1 & 339 & $99-102$ \\
\hline$Y$ & $\mathrm{CC}$ & c & 2 full columns & 124 & $73-70$ & WTC 1 & 124 & $70-73$ \\
\hline Does not match & $k-1$ or $k-13$ & C & 3 columns, lower $1 / 3 r d$ & 209 & $97-100$ & WT 1 & 209 & $97-100$ \\
\hline Y & $K-2$ or $K-40$ & C. & 1 column, lower $2 / 3 r d s$ & 236 & $92-95$ & WTC 1 & 236 & $92-95$ \\
\hline$Y$ & $M-2$ & c & Full panel & -9 & $<63>$ & MTC 1 & 130 & 96.99 \\
\hline & $M-10 a$ & c & 3 columns, $1 / 3 r d$, not labeled but attached to $M-10 b$ & E209 & $82-85$ & MTC 2 & 209 & $82-85$ \\
\hline$Y$ & $M-10 b$ & C & 3 columns, lower $1 / 2$ & B206 & $83-86$ & MTC 2 & 206 & $83-86$ \\
\hline & $M-20$ & C & 2 columns, lower $1 / 3$ rd & A121 & $99-102$ & WTC 1 & 121 & 99-102 \\
\hline & $M-26$ & c & 3 full columns & A130 & 1:90-93 & MTC 1 & 130 & $90-93$ \\
\hline & M-27 & C & 2 columns, lower $3 / 4$ ths & A130 & : $93-96$ & MTC 1 & 130 & $93-96$ \\
\hline & $M-28$ & C & 3 columns, lower $1 / 4$ th & E345: & $9 x-1 x x$ & MTC 2 & 345 & $98-101$ \\
\hline & $M-30$ & C & 2 columns, lower $1 / 3 r d$ & -33 & $94-97$ & MTC 1 & 133 & $94-97$ \\
\hline Y & $\mathrm{N}-1$ & c & 2 full columns & 28 & $82-85$ & MTC 1 & 218 & 82.85 \\
\hline$Y($ as $M-3)$ & $N-7$ or $M-3$ & C & 3 full columns & $127:$ & $97-100$ & MTC 1 & 127 & $97-100$ \\
\hline$Y($ as $M-7)$ & $N-8$ or $M-7$ & C & Full panel & A142 & $97-100$ & MTC 1 & 142 & $97-100$ \\
\hline$Y($ as $M-8)$ & $N-9$ or $M-8$ & C & Almost full panel, missing lower $1 / 3$ rd of 1 column & A154: & $101-104$ & MTC 1 & 154 & $101-104$ \\
\hline$Y(\operatorname{as~M-15)}$ & $\mathrm{N}-10$ or $\mathrm{M}-15$ & C & 2 columns, lower $2 / 3$ rds & A115 & 89.92 & MTC 1 & 115 & 89.92 \\
\hline$Y(\operatorname{as~} M-13)$ & $N-12$ or $M-13$ & C & 2 full columns & -06 & $92-95$ & WTC 1 & 206 & 92.95 \\
\hline$Y($ as M-14) & $N-13$ or $M-14$ & C & 3 columns, lower $1 / 3 r d$ & A130 & :99-102 & WTC 1 & 130 & $99-102$ \\
\hline & N-99 or M-16 & C & Almost full panel, missing lower $1 / 3$ rd of 1 column & A.148 & $99-102$ & MTC 1 & 148 & $99-102$ \\
\hline & $N-101$ or M-21 & C & 3 full columns & A133: & $100-103$ & WTC 1 & 133 & $100-103$ \\
\hline & S-1 or EE & C & 2 columns, lower $1 / 3 r d$ & $\mathrm{~A} 433$ & 3: $79-82$ & WTC 1 & 433 & $79-82$ \\
\hline Y & $5-9$ or $C-63$ & c & Full panel & A133 & $97-100$ & WTC 1 & 133 & $97-100$ \\
\hline$Y$ & $S-10$ or $C-17$ & c & 2 columns, lower $1 / 2$ & 224 & $92-95$ & MTC 1 & 224 & $92-95$ \\
\hline Y & $S-14$ or $C-20$ & C & Fụll panel & $B 218$ & 8: $91-94$ & WTC 2 & 218 & $91-94$ \\
\hline
\end{tabular}

Table A-3. List of partially identified exterior panel sections.

In FEMA repor? $\frac{\text { NIST Name }}{\mathrm{C}-117} \quad \frac{\text { Type }}{\mathrm{C}} \frac{\text { Brief Description }}{3 \text { columins lower } 1 / 3} \quad \frac{\text { Markings }}{101-104} \frac{\text { Bidg }}{\text { NA }}$ Column Floors




\begin{tabular}{|c|c|c|c|c|}
\hline In FEMA repon?? & NIST Name & Type & Brief Description & Location \\
\hline \multirow[t]{2}{*}{$Y$} & C-28B (formerly U-4) & $\mathrm{CC}$ & Corner column, in 2 pieces & 205 \\
\hline & $M-35$ & $\mathrm{CC}$ & Corner columin & 205 \\
\hline Y & AA (formerly U-7) & C & 2 full columns, thick walled & $\mathrm{PL}$ \\
\hline$Y(N S F)$ & ASCE-3 & $c$ & 1 column, bottom $1 / 3$ rd of left columin & $\mathrm{PL}$ \\
\hline Y & $\mathrm{BB}$ & c & Single, thick column & 205 \\
\hline Y & $c-11$ & c & 2 columns, upper $2 / 3$ rds & 205 \\
\hline Y & $\mathrm{C}-15$ (formerly U-20) & C & Partial of single column & 205 \\
\hline Y & $\mathrm{C}-16$ & C & 1 column, upper $1 / 3 r d$ & 205 \\
\hline Y & C.16a & C & Fell of during moving of $C-16$ & 205 \\
\hline$Y$ & C.28 (formerly U-1) & c & 1 column of unknown location & 205 \\
\hline Y & $\mathrm{C}-32$ & C & 1 column, upper $1 / 3$ rd & 236 \\
\hline Y & $C-41$ & c & 1 column, lower $2 / 3 \mathrm{rds}$ & 205 \\
\hline \multirow[t]{2}{*}{$\mathrm{Y}$} & $C-43$ & C & 1 column, lower $1 / 2$ & 205 . \\
\hline & $C-47$ & c & 3 columns, upper $1 / 2$ & 236 \\
\hline$\dot{y}$ & C- 49 or $5-6$ & C & portion of 1 column & 236 \\
\hline$Y$ & $c-51$ & C & 2 columns, upper $1 / 2$ & 205 \\
\hline Y & C-52 & c & 1 column, upper $2 / 3$ rds & 205 \\
\hline 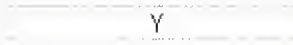 & C. 54 & C & 1 column, small piece with extended outer web & 205 \\
\hline Y & c-64 & c & 1 column with a lot missing & $205^{\circ}$ \\
\hline Y & c- 67 & C & 1 column, rest uniknown & 205 \\
\hline Y & C- 68 & c & 1 column, upper $1 / 2$ & 205 \\
\hline $\mathrm{Y}$ & C.73 & c & 1 column, upper $1 / 2$ & 205 \\
\hline$\gamma$ & C-75 & c & portion of 1 column and spandrel, rest unknown & 236 \\
\hline Y & C.77 & c & 2 columns from different panels attached at spandrel, $13 \mathrm{rd}$ of each & 205 \\
\hline \multirow[t]{3}{*}{$Y(N S F)$} & C.84 & c & 1 full column, stampings on front face & $\mathrm{PL}$ \\
\hline & C- -102 & C & Partial of single column & 205 \\
\hline & C-133 & $\mathrm{C}$ & 1 column, bottom $1 / 3 r d$ of unknown location & 205 \\
\hline Y & DD & C & 1 Column, spans 1 floor and has end plates on both ends & 205 \\
\hline$\gamma$ & $\mathrm{FF}$ & c & Single, thick column & 205 \\
\hline \multirow[t]{2}{*}{$Y$} & $k-16$ & c & 1 full column, thick, looks very corroded & $\mathrm{FL}$ \\
\hline & K-16a (formerly U-23) & $\mathrm{C}$ & Fell of of $\mathrm{K}-16$ while moving & $\mathrm{PL}$ \\
\hline \multirow[t]{2}{*}{$\begin{array}{l}\text { Both are in report but } \\
\text { listed separately }\end{array}$} & $M-4$ or $M-5$ & $\mathrm{C}$ & 3 columns, upper $2 \beta$ rds & 205 \\
\hline & $M-19$ & C & 2 columns, upper $1 / 3 r d$ & 205 \\
\hline $\mathrm{Y}$ & $\mathrm{N}-3$ & $c$ & 1 column, upper $1 / 2$ & 236 \\
\hline Y & $1-4$ & $\mathrm{C}$ & 1 column, middle $1 / 3 \mathrm{rd}$ & 236 \\
\hline $\mathrm{Y}$ & N-6 (formerly U-2) & $\mathrm{c}$ & 1 column, length of spandrel, crushed & 236 \\
\hline$Y($ as $M-9)$ & $\mathrm{N}-11$ or $\mathrm{M}-\mathrm{9}$ & $\mathrm{c}$ & 3 columns, upper 23 rds & 205 \\
\hline$Y$ (as C-19) & $N-N$ or C-19 & $\mathrm{C}$ & 1 column, lower $1 / 2$ & 205 \\
\hline \multirow[t]{4}{*}{$Y($ as $C-50)$} & $S-3$ or $\mathrm{C}-50$ & c & 1 column, unknown $1 / 2$ & 205 \\
\hline & & & & \\
\hline & U-6 & C & 3 columns, upper $1 / 4$ & 236 \\
\hline & U-15 & $\mathrm{c}$ & Partial of single column & 205 \\
\hline $\mathrm{Y}$ & $k-10$ & $\mathrm{Cn}$ & Flange coupon received from Gross, July 29, 2002 & Lab \\
\hline Y & $k-11$ & $\mathrm{Cn}$ & Flange coupon received from Gross, July 29, 2002 & Lab \\
\hline$\dot{y}$ & $\mathrm{~K}-12$ & $\mathrm{Cn}$ & Flange coupon received from Gross, July 29, 2002 & Lab \\
\hline Y & $\mathrm{k}-13$ & $\mathrm{Cn}_{\mathrm{n}}$ & Flange coupon received from Gross, July 29, 2002 & Lab \\
\hline$\gamma$ & $\mathrm{K}-14$ & $\mathrm{Cn}_{\mathrm{n}}$ & Flange coupon received from Gross, July 29, 2002 & Lab \\
\hline Y & $k-15$ & $\mathrm{Cn}$ & Flange coupon received from Gross, July 29, 2002 & $\mathrm{Lab}$ \\
\hline Y & $k-18$ & $\mathrm{Cn}$ & Flange coupon received from Gross, July 29,2002 & Lab \\
\hline Y & $K-19 a$ & $\mathrm{Cn}$ & Flange coupon received from Gross, July 29, 2002 & Lab \\
\hline \multirow[t]{3}{*}{ Y } & $\mathrm{K}-19 \mathrm{~b}$ & $\mathrm{Cn}$ & Flange coupon received from Gross, July 29, 2002 & Lab \\
\hline & B-5004 & BT & Bowtie section & JFK/PL \\
\hline & E-5007 & BT & Bowtie section & JFKUPL \\
\hline
\end{tabular}


Table A-5. List of identified core columns.

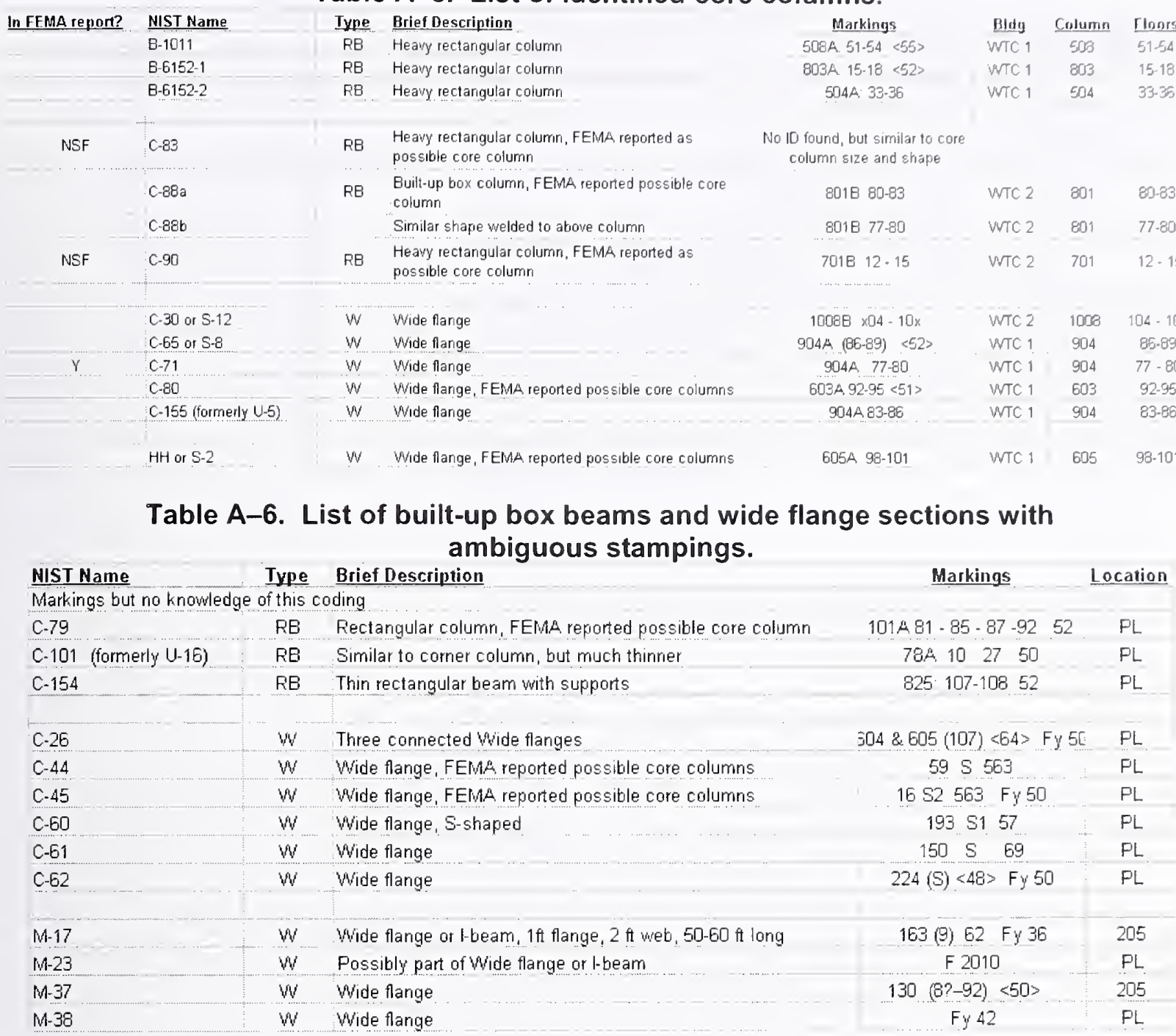


Table A-7. List of unidentified wide flange sections.

\begin{tabular}{|c|c|c|c|c|}
\hline In FEMA report? & NIST Name & Type & Brief Description & Location \\
\hline & Ei-1022 & $w$ & Thick wide flange with severe bend & 205 \\
\hline & B-1075 & m & Wide flange & 205 \\
\hline$\gamma$ & C-29 (formerly U-10) & W & Wide flange & 205 \\
\hline$y$ & $c-35$ & W & Wide flange & 205 \\
\hline $\mathrm{Y}$ & $c-69$ & m & Wide flange & 205 \\
\hline$\gamma$ & c.70 (formerly (J-9) & w & Wide flange & 205 \\
\hline $\mathrm{Y}$ & $c-72 b$ & M & Wide flange & 205 \\
\hline $\mathrm{Y}$ & C.76 & w & Wide flange & 205 \\
\hline Y & C-78 (formerly U-B) & W & Wide flange & 205 \\
\hline$\gamma$ & $\mathrm{C}-81$ & w & Wide flange & 205 \\
\hline$\gamma$ & c-82 & W & Wide flange & 205 \\
\hline$Y(N S F)$ & C.85 & w & Mide flange & 205 \\
\hline \multirow[t]{7}{*}{$Y$} & $c-87$ & W & Thick Wide flange & 205 \\
\hline & $c-123$ & m & Small Wide flange & 205 \\
\hline & $C-126$ & W & Wide flange & 205 \\
\hline & $c-130$ & m & Wide flange & 205 \\
\hline & $c-138$ & w & Wide flange & 205 \\
\hline & C. 142 & W & Wide flange & 205 \\
\hline & $c-150$ & W & Wide flange & 205 \\
\hline \multirow[t]{5}{*}{$\gamma$} & $M-11$ & m & Mide flange & 205 \\
\hline & $M-18$ & $\mathrm{RB}$ & Large box beam & 205 \\
\hline & $M-22$ & $\mathrm{FB}$ & Large box beam & 205 \\
\hline & $M-33$ & in & Mide flange & 205 \\
\hline & $5 \mathrm{M}-2$ & W & Wide flange & 205 \\
\hline $\mathrm{Y}$ & W-14A or $\mathrm{A}$ & W & Heavy Wide flange & 205 \\
\hline$\gamma$ & $M-14 \mathrm{~B}$ & wi & Heawy Wide flange & PL \\
\hline
\end{tabular}




\begin{tabular}{|c|c|c|c|c|}
\hline In FEMA report? & NIST Name & Type & Brief Description & Location \\
\hline$Y$ & $C-53$ & J & Floor truss & $\mathrm{PL}$ \\
\hline \multirow[t]{4}{*}{$\gamma$} & $C-53 \mathrm{~B}$ & 」 & Floor truss & $\mathrm{PL}$ \\
\hline & $C-100$ & $J$ & Possible angle from a floor truss & PL \\
\hline & $c-104$ & j & Possible angle from a floor truss & FL \\
\hline & C-106 (formerly U-18) & J & Srrall piece of floor truss & 202 \\
\hline \multirow{17}{*}{ K6 } & $C-115$ & J & Pig-tailed piece from floor truss & Lat \\
\hline & c-122 & J & Piece of floor truss & $\mathrm{PL}$ \\
\hline & $c-131$ & J & Small portion of floor truss with cement & 202 \\
\hline & $c-132$ & J & Piece of floor truss & PL \\
\hline & $\mathrm{C}-137 \mathrm{a}$ & J & Piece of floor truss & $\mathrm{PL}$ \\
\hline & $\mathrm{C}-137 \mathrm{~b}$ & J & Plece of floor truss & $\mathrm{PL}$ \\
\hline & $c-137 c$ & J & Piece of floor truss. & PL \\
\hline & $c-137 d$ & j & Piece of floor truss & PL \\
\hline & $c-137 f$ & J & Piece of floor truss & PL \\
\hline & $C-140$ & J & Piece of angle & $\mathrm{PL}$ \\
\hline & $c-146 b$ & J & Piece of floor truss & $\mathrm{PL}$ \\
\hline & $c-149$ & J. & Piece of floor truss & PL \\
\hline & $c-151$ & J & Piece of floor truss & $\mathrm{PL}$ \\
\hline & $M-25$ & J & Small piece of floor truss & 202 \\
\hline & $M-31$ & J & Pieces of floor truss & Lab \\
\hline & $\mathrm{M}-32$ & J & Pieces of floor truss & Lab \\
\hline & $M-36$ & $\mathrm{~J}$ & Thick angle from floor truss & $\mathrm{PL}$ \\
\hline$Y(\operatorname{as~} N-2)$ & $\mathrm{T}-1$ or $\mathrm{N}-2$ & J & Floor truss & 202 \\
\hline
\end{tabular}

Table A-9. List of recovered channel material.

\begin{tabular}{|c|c|c|c|c|}
\hline In FEMA report? & NIST Name & Type & Brief Description & Lacation \\
\hline \multirow[t]{25}{*}{$Y$} & $c-91$ & $\mathrm{Ch}$ & Channel & 236 \\
\hline & C-95 & $\mathrm{Ch}$ & Channel & 236 \\
\hline & C.96 & $\mathrm{Ch}$ & Channel & 236 \\
\hline & C-97 & $\mathrm{Ch}$ & Channel & 236 \\
\hline & C.98 & $\mathrm{Ch}$ & Charinel & 236 \\
\hline & C-99 & $\mathrm{Ch}$ & Channel & 236 \\
\hline & $C-105$ & $\mathrm{Ch}$ & Channel & 236 \\
\hline & C-107 (formerly U-19) & $\mathrm{Ch}$ & Channel & 236 \\
\hline & $C-118$ & $\mathrm{Ch}$ & Charinel & 236 \\
\hline & C- 124 & $\mathrm{Ch}$ & Channel & 236 \\
\hline & C- 125 & $\mathrm{Ch}$ & Channel & 236 \\
\hline & $C-128$ & $\mathrm{Ch}$ & Channel & $\mathrm{B}$ \\
\hline & C -129 & $\mathrm{Ch}$ & Channel & 236 \\
\hline & $C-134$ & $\mathrm{Ch}$ & Channel & 236 \\
\hline & $C-139$ & $\mathrm{Ch}$ & Channel & 236 \\
\hline & C. 141 & $\mathrm{Ch}$ & Channel & 236 \\
\hline & $C-143$ & $\mathrm{Ch}$ & Channel & 236 \\
\hline & $C-144$ & $\mathrm{Ch}$ & Channel & 236 \\
\hline & C- 145 & $\mathrm{Ch}$ & Channel & 236 \\
\hline & $c-147$ & $\mathrm{Ch}$ & Channel & 236 \\
\hline & $C-148$ & $\mathrm{Ch}$ & Channel & 236 \\
\hline & $C-152$ & $\mathrm{Ch}$ & Channel & 236 \\
\hline & $C-153$ & $\mathrm{Ch}$ & Channel & 236 \\
\hline & $M-24$ & $\mathrm{Ch}$ & Channel & 236 \\
\hline & $M-34$ & $\mathrm{Ch}$ & Channel & $B$ \\
\hline
\end{tabular}


Table A-10. List of material from WTC 5.

\begin{tabular}{|c|c|c|c|c|}
\hline In FEMA report? & NIST Name & Type & Brief Description & Location \\
\hline & $G Z-1$ & $\mathrm{Cn} 5$ & Coupon from Eldg & Lab \\
\hline & $G Z-2$ & $\mathrm{Cn} 5$ & Coupon from Bldg & Lab \\
\hline & GZ-3 & Cn5 & Coupon from Bldg $\$$ & Lab \\
\hline & $G Z-4$ & $\mathrm{Cn} 5$ & Coupan from Bidg $\$ 5$ & Lab \\
\hline & GZ-5 & $\mathrm{Cn} 5$ & Coupon from Bidg $\$ 5$ & Lab \\
\hline & $G Z-6$ & $\mathrm{Cn} 5$ & Coupon from Eldg \#5 & Lab \\
\hline & GZ-7 & Cn5 & Coupon from Bldg $\$ 5$ & Lab \\
\hline
\end{tabular}

Table A-11. List of miscellaneous material.

\begin{tabular}{|c|c|c|c|c|}
\hline In FEMA report? & NIST Name & Type & Brief Description & $\frac{\text { Location }}{\text { Lab }}$ \\
\hline & C-18 Associated & B & One washer and nut & Lab \\
\hline & $c-108$ & $B$ & Three sheared bolts. & $\mathrm{Lab}$ \\
\hline & $c-109$ & B & Single bolt sheared & Lab \\
\hline & $c-110$ & B & Bolt and nut & Lab \\
\hline & $c-111$ & B & Bolt and washer & Lab \\
\hline & $c-112$ & B & Single bolt sheared & Lab \\
\hline & C-113 & $\mathrm{B}$ & Two sheared bolts with washers & Lab \\
\hline & C-114 & B & Sheared bolt with nut & Lab \\
\hline & M-26 associated & B & 8 bolts and a nut & Lab \\
\hline & $c-116$ & $\mathrm{H}$ & Damper & Lab \\
\hline & B-1044-1 & 0 & Piece of crushed metal decking as soc with B-1044 & 202 \\
\hline & $\mathrm{B}-2150$ & o & Pieces of aluminum she athing & 202 \\
\hline & $\mathrm{Cs8c}$ (formerly U-22) & 0 & Broke off C-88 & $\mathrm{PL}$ \\
\hline & C-94 & 0 & May be some type of brace, rectangular box construction & $\mathrm{PL}$ \\
\hline & C-103 & 0 & Square-tube construction & PL \\
\hline & C-119A A & o & Square-tube construction & $P L$ \\
\hline & $c-119 B$ & 0 & Square-tube construction & $P L$ \\
\hline & $\mathrm{c}-120$ & 0 & Square-tube construction & $\mathrm{PL}$ \\
\hline & $C-121$ & o & Square-tube construction & $\mathrm{PL}$ \\
\hline & $c-135$ & 0 & May be some type of brace, rectangular box construction & $\mathrm{PL}$ \\
\hline & $c-146$ & 0 & Mangled ball of steel and concrete & 202 \\
\hline & C-156 (formerly U-17) & 0 & Square-tube construction & $\mathrm{PL}$ \\
\hline Y & K-50a & 0 & Rectarigular slab of steel with bolts, received from D. Sharp, SEAoNY & Lab \\
\hline $\mathrm{Y}$ & $\mathrm{K}-50 \mathrm{~b}$ & 0 & Rectangular slab of steel with bolts, received from D. Sharp, SEAONY & Lab. \\
\hline$Y$ & $K-50 c$ & 0 & Rectangular slab of steel with bolts, recerved from D. Sharp, SEAONY & Lab \\
\hline & $M-17$ a (formerly $U-24$ ) & 0 & Fell off of $M-17$ while moving & 202 \\
\hline & $M-29$ & 0 & $5 \mathrm{ft}$ piece of strapping & 202 \\
\hline & $M-30$ associated & 0 & Pieces of glass, plexiglass, other rubble & Lab \\
\hline Y & N-5 & 0 & Plate with bolts. & $\mathrm{PL}$ \\
\hline & $\mathrm{U}-25$ & 0 & Unknown Wide flange with concrete. & 205 \\
\hline
\end{tabular}


A.2 REPRESENTATIVE PICTURES OF RECOVERED WTC STEEL 

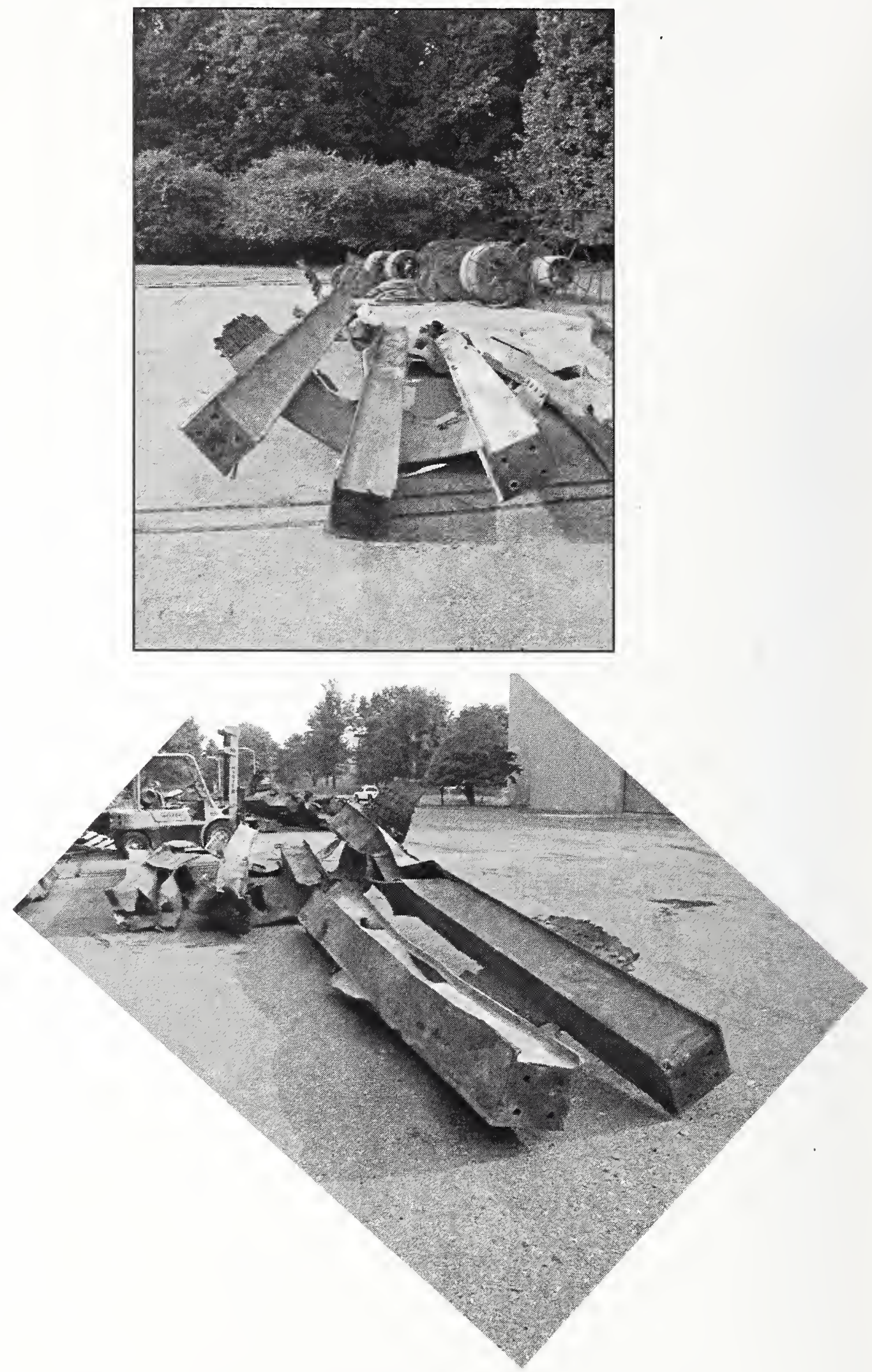

Source: NIST.

Figure A-1. Exterior column panel, sample C-46 shown. 


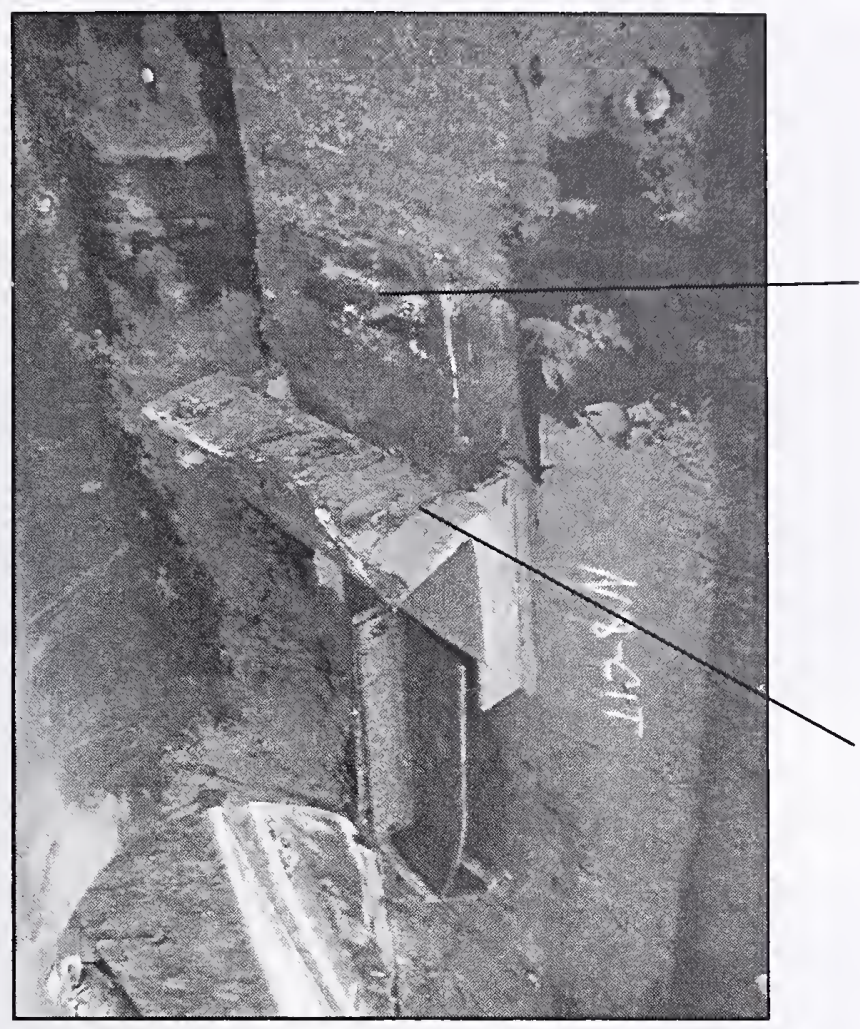

Welded gusset plate

Seat with 2 intact bolt holes for floor truss attachment. Intact bolt remains in far hole.

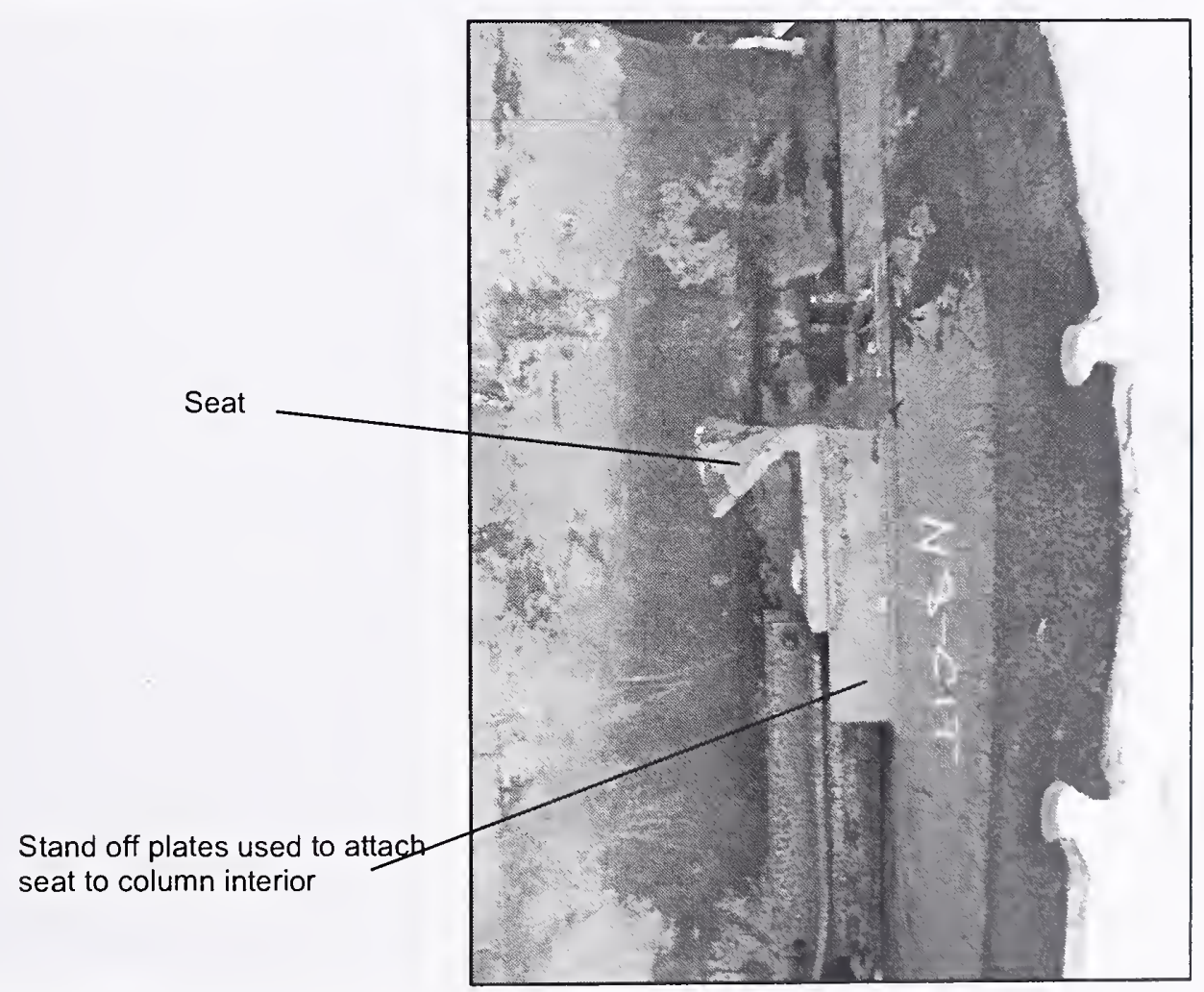

Source: NIST.

Figure A-2. Floor truss seats shown from sample N-8. 


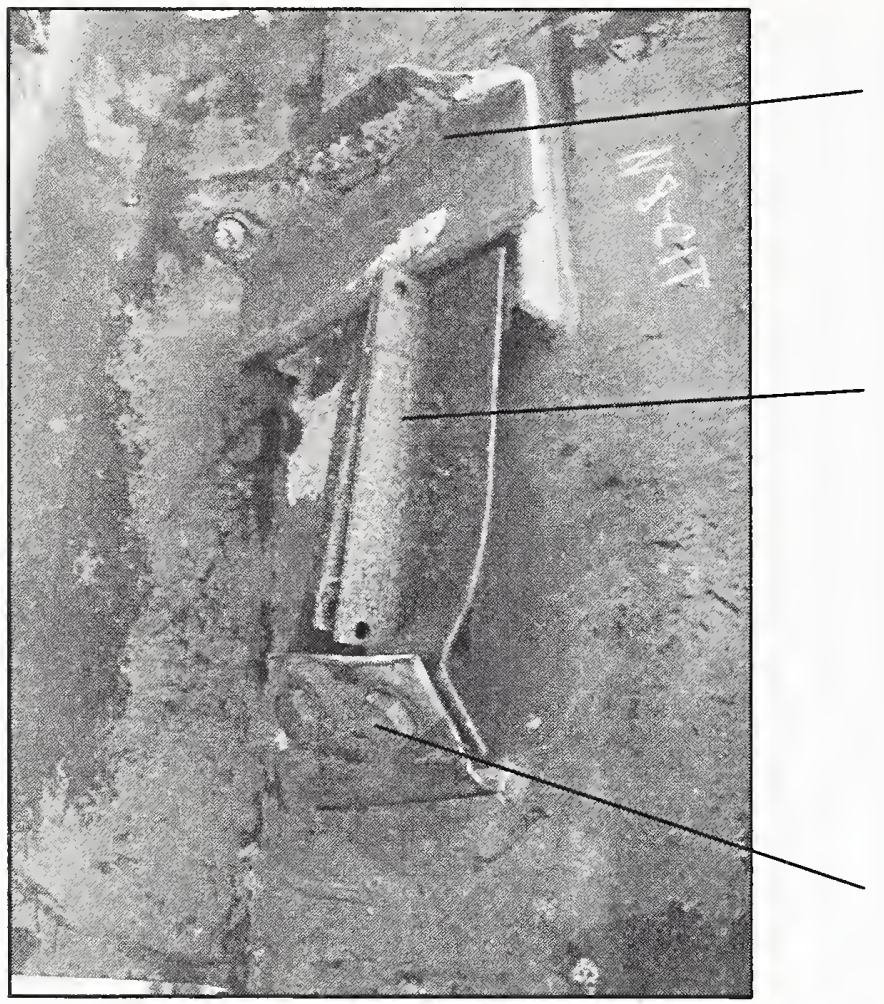

Seat

Damping unit with missing viscoelastic material. Damping unit has been bent into an upright position.

Figure A-3. Damping Unit shown from sample N-8.

Welded gusset plate used in place of seat on alternate column/spandrel intersections. One method used to attach diagonal bracing strap to exterior wall

Gusset plate for viscoelastic damping unit attachment to column interior.

Source: NIST

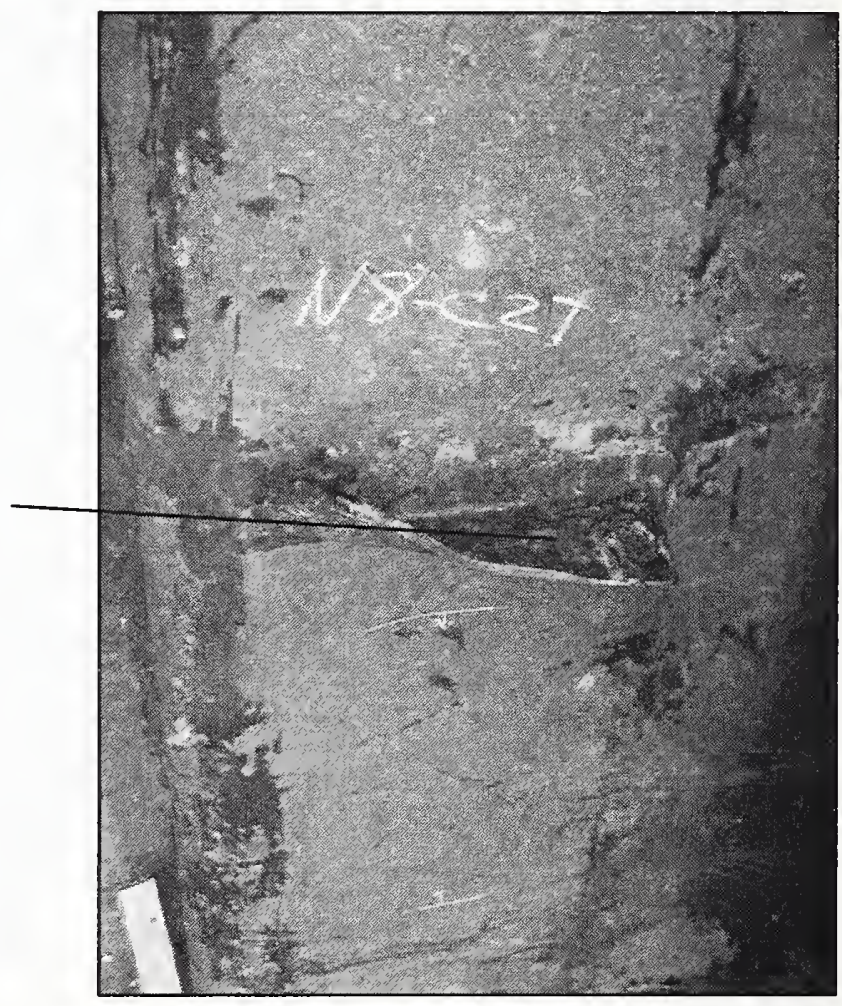

Figure A-4. Gusset plate shown from sample N-8. 


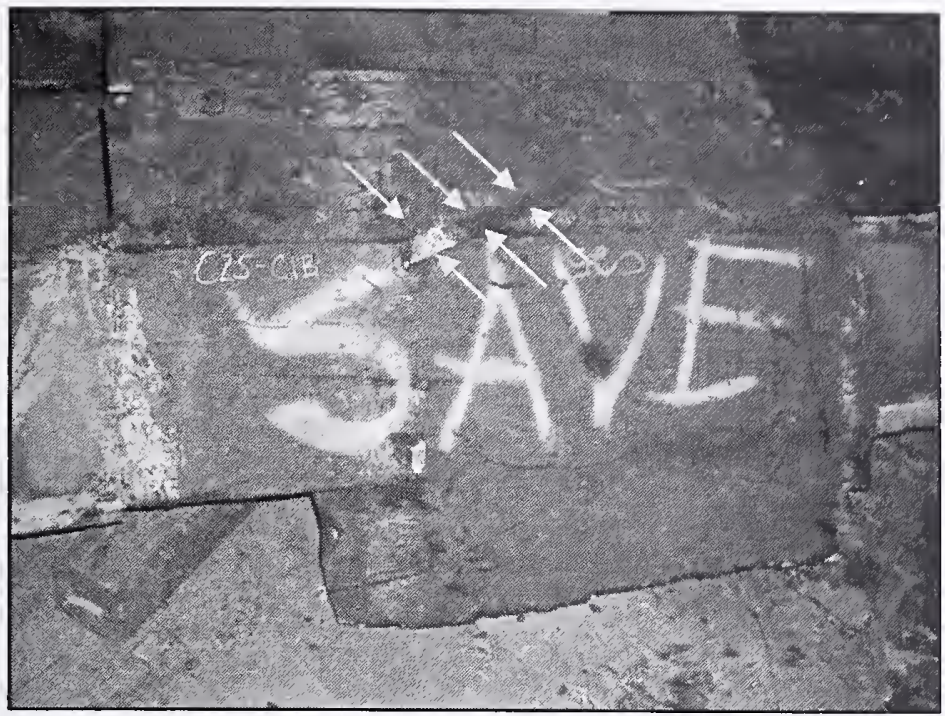

Diagonal bracing strap attached directly to exterior column

On Sample C-25

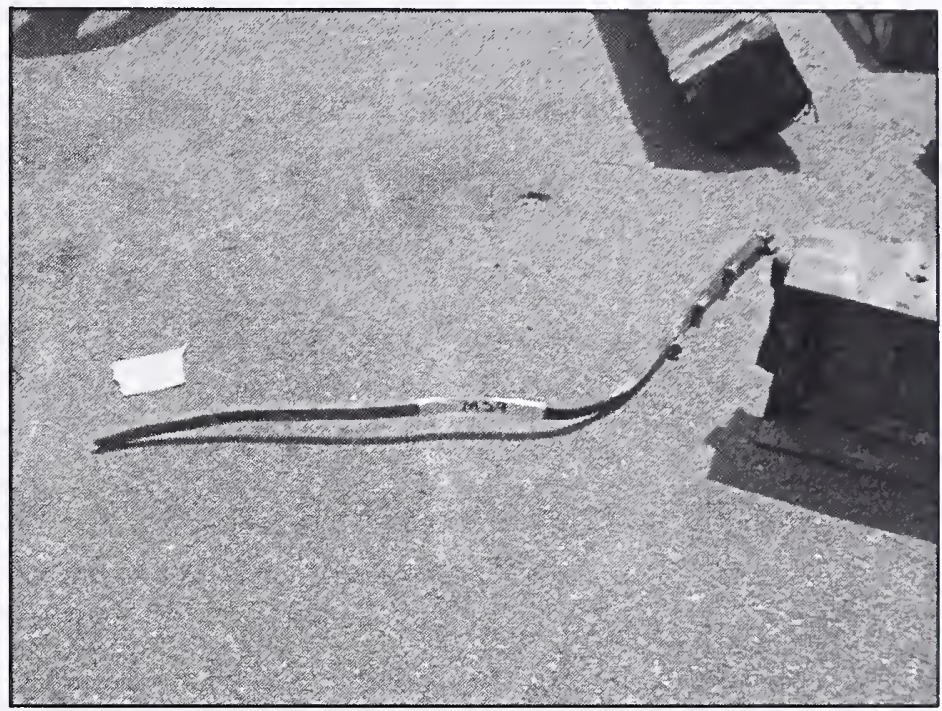

Source: NIST.

Figure A-5. Diagonal bracing strap shown on sample C-25 (top), and single strap labeled M-29 (bottom). 


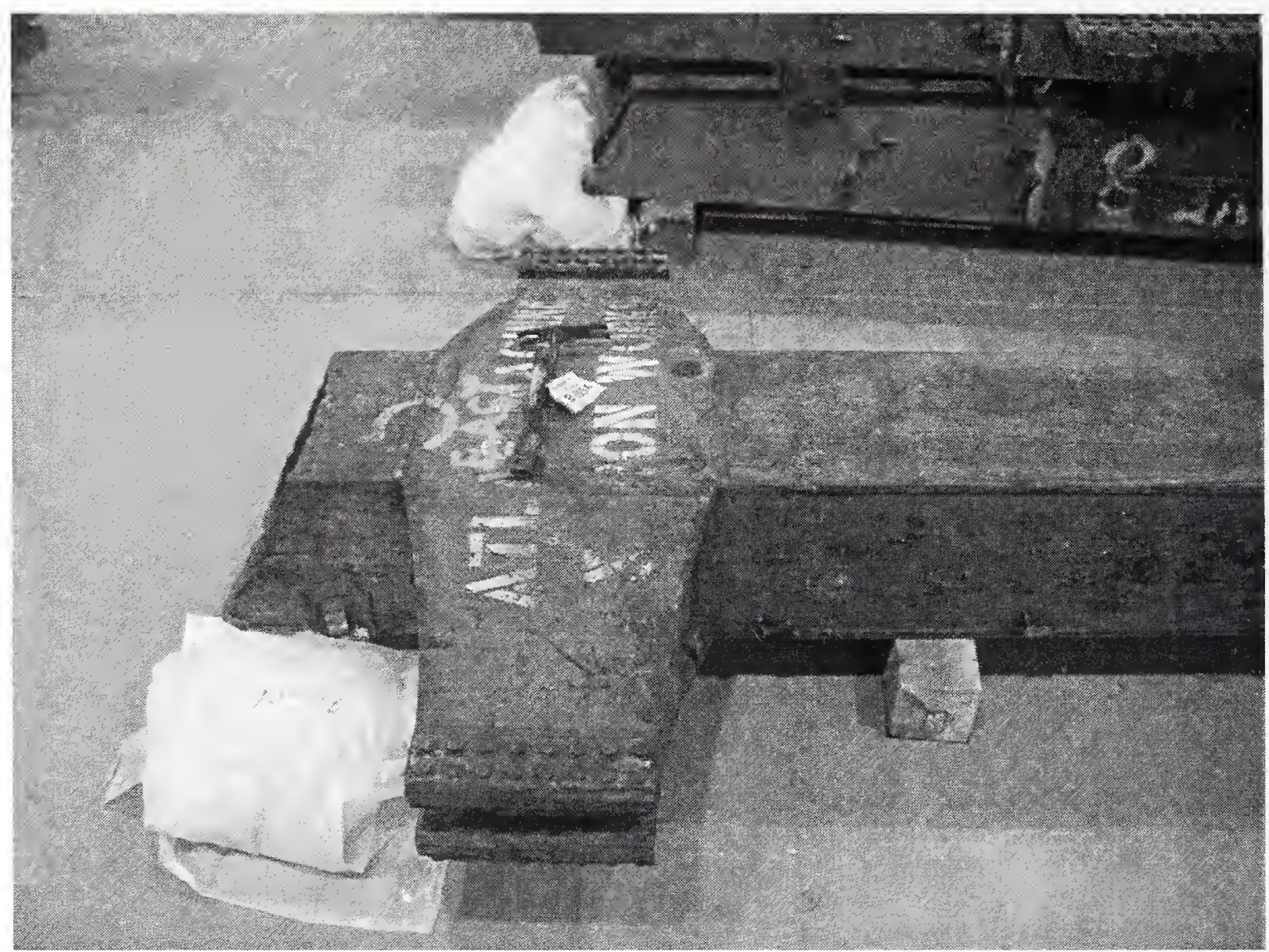

\section{B-5004 at JFK}

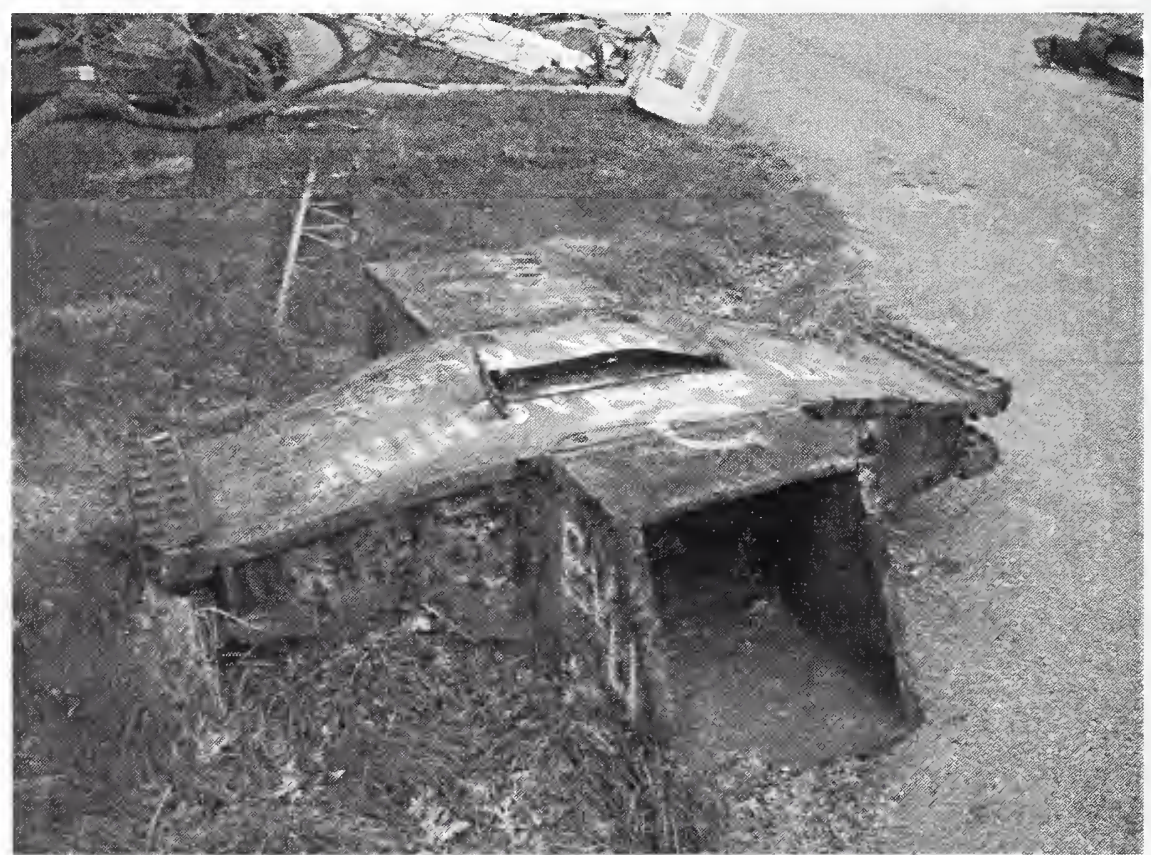

B-5004 portion cut and moved to NIST campus

Source: NIST.

Figure A-6. Bowtie section of exterior wall. 

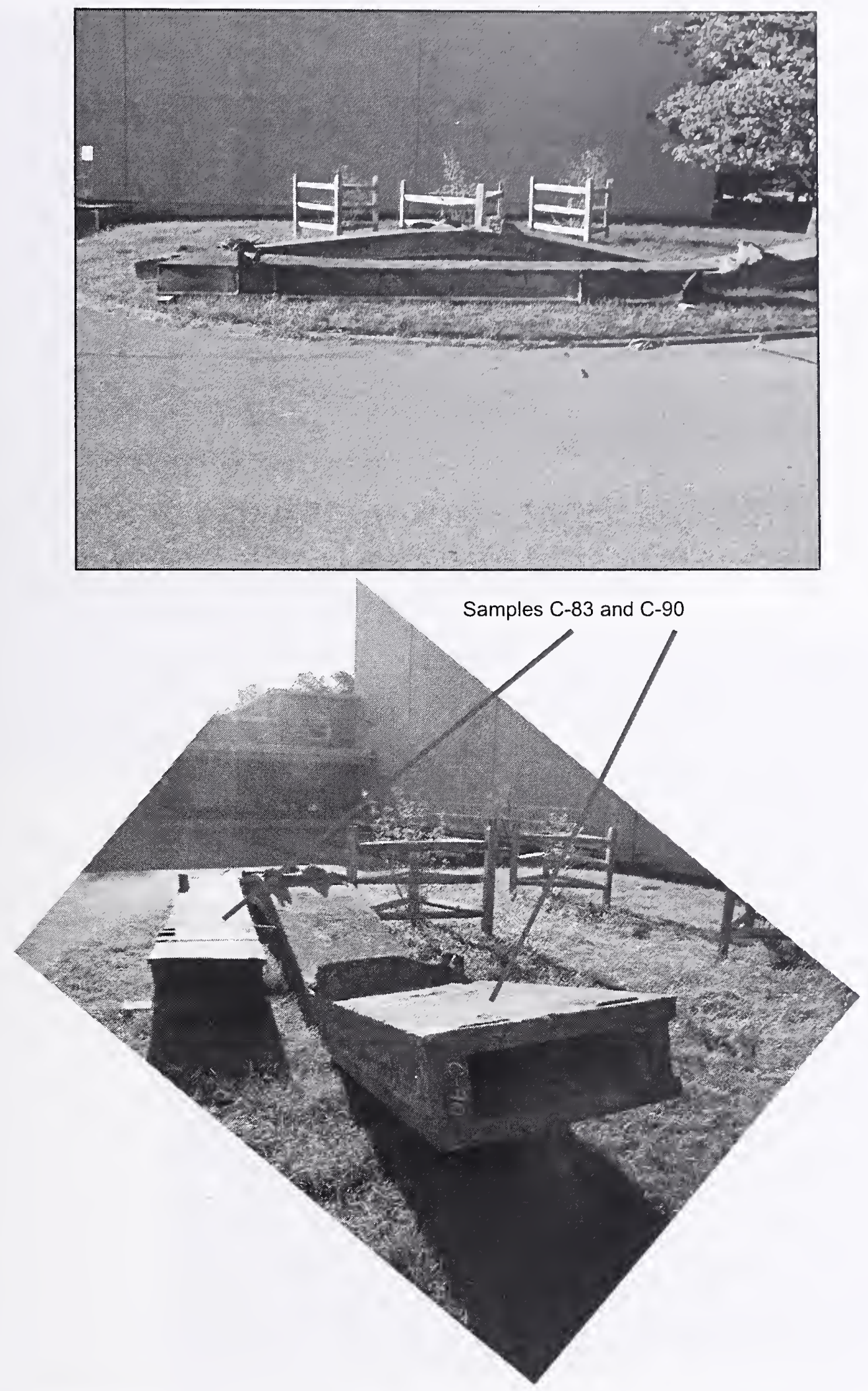

Source: NIST.

Figure A-7. Recovered rectangular built up box sections used as core columns. 


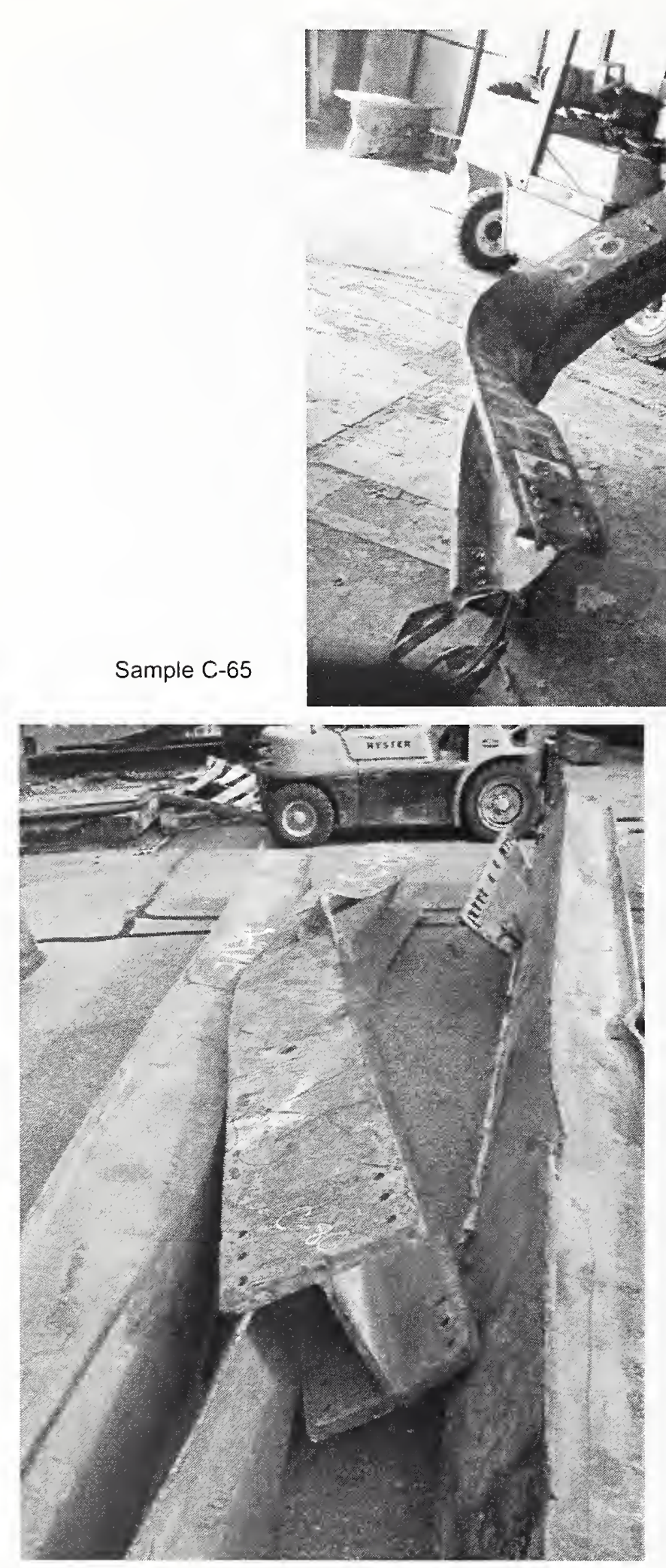

Sample C-80

Source: NIST.

Figure A-8. Recovered wide flange sections used as core columns. 

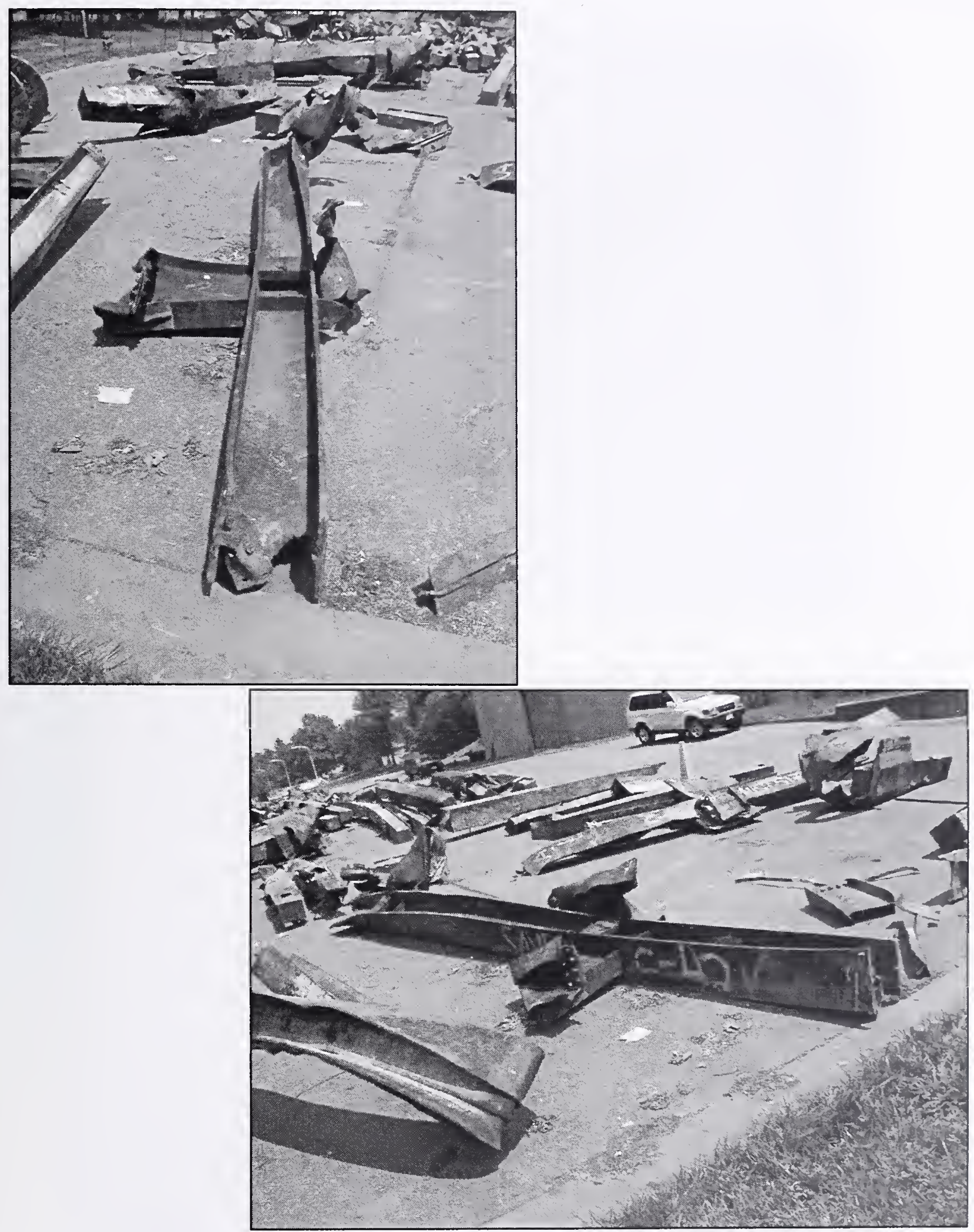

Source: NIST.

Figure A-9. Other recovered wide flange sections, shown is sample C-42. 

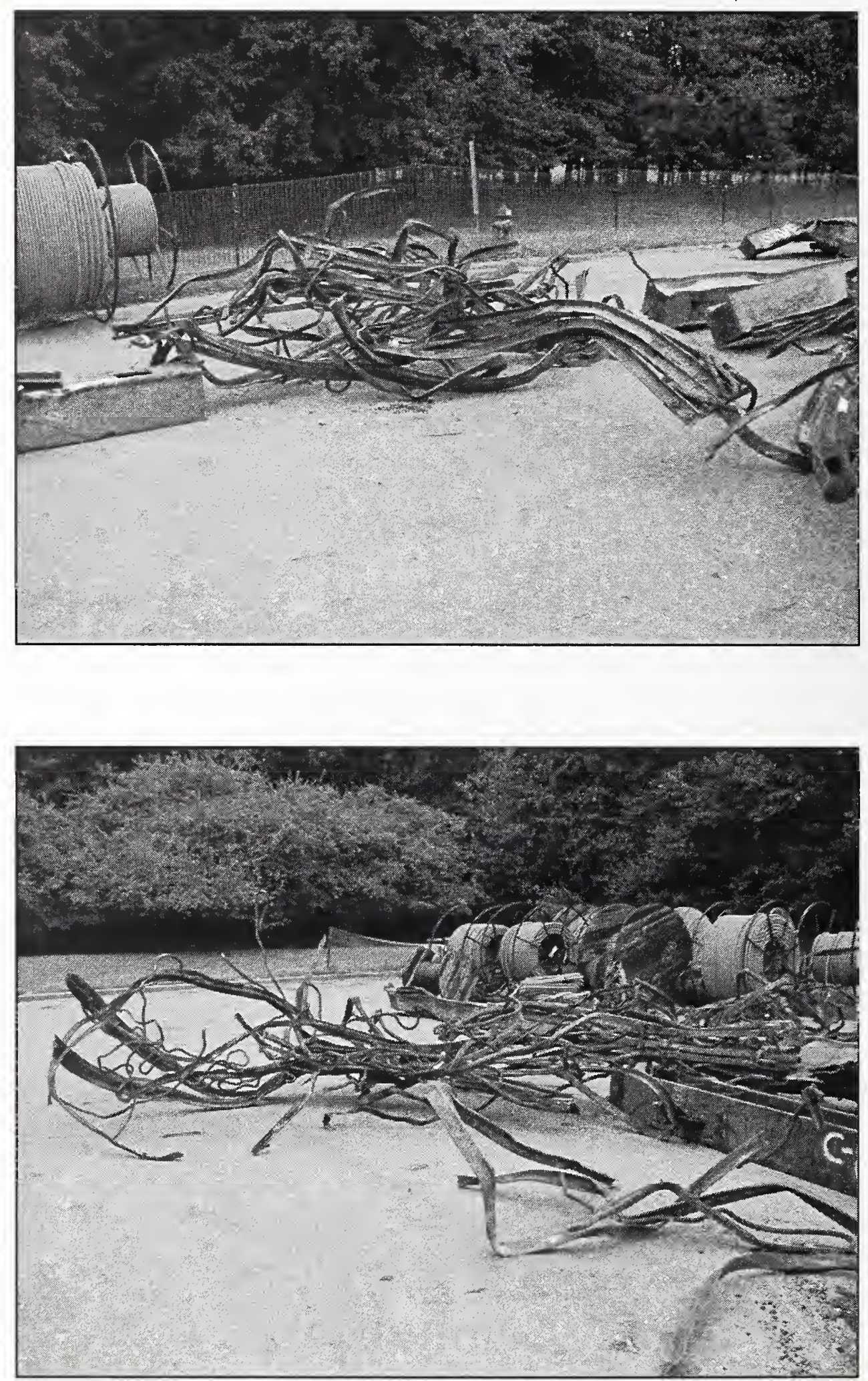

Source: NIST.

Figure A-10. Recovered floor truss material; shown are portions of sample C-53. 


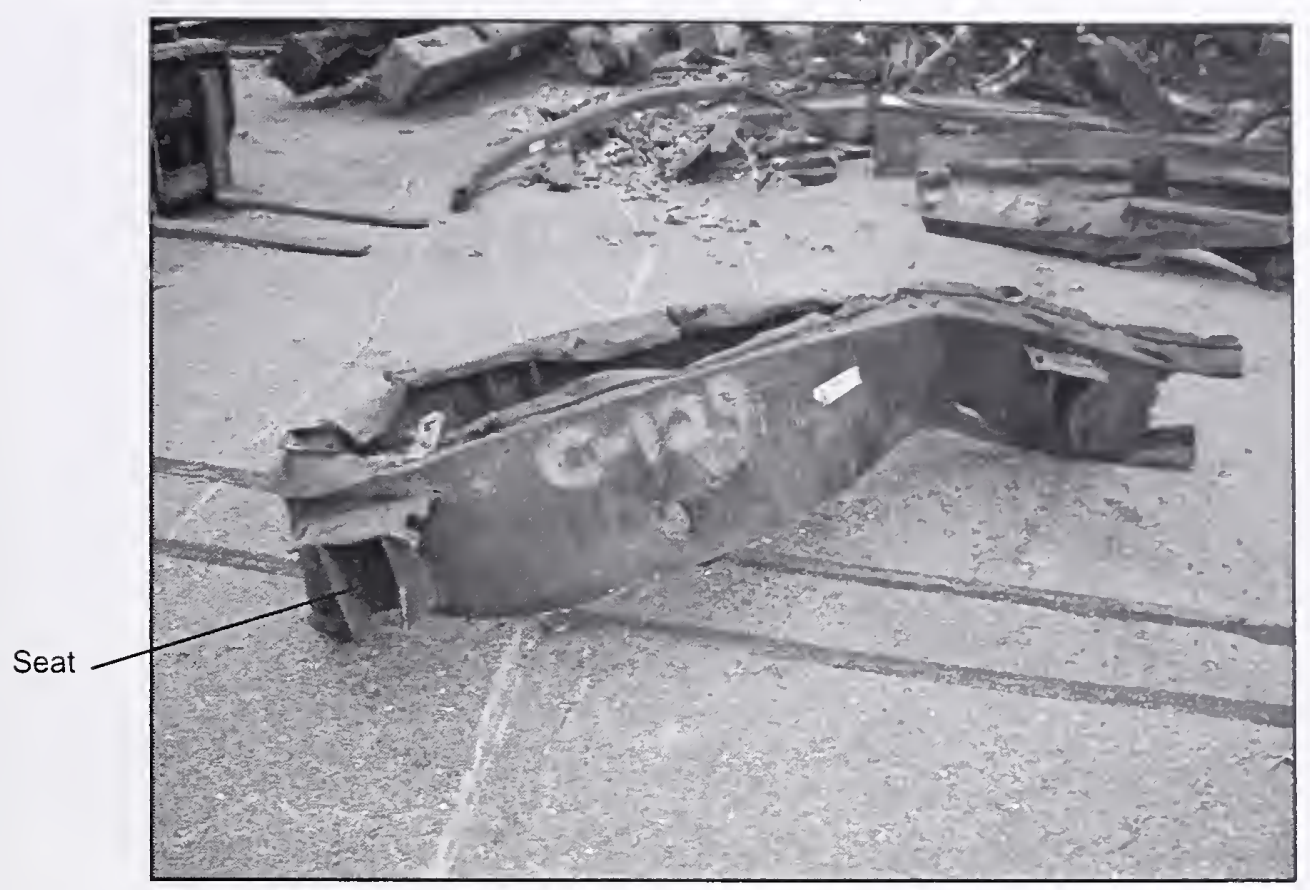

Source: NIST.

Figure A-11. Recovered inner channel material used to connect floor trusses to core columns; shown is sample C-129.
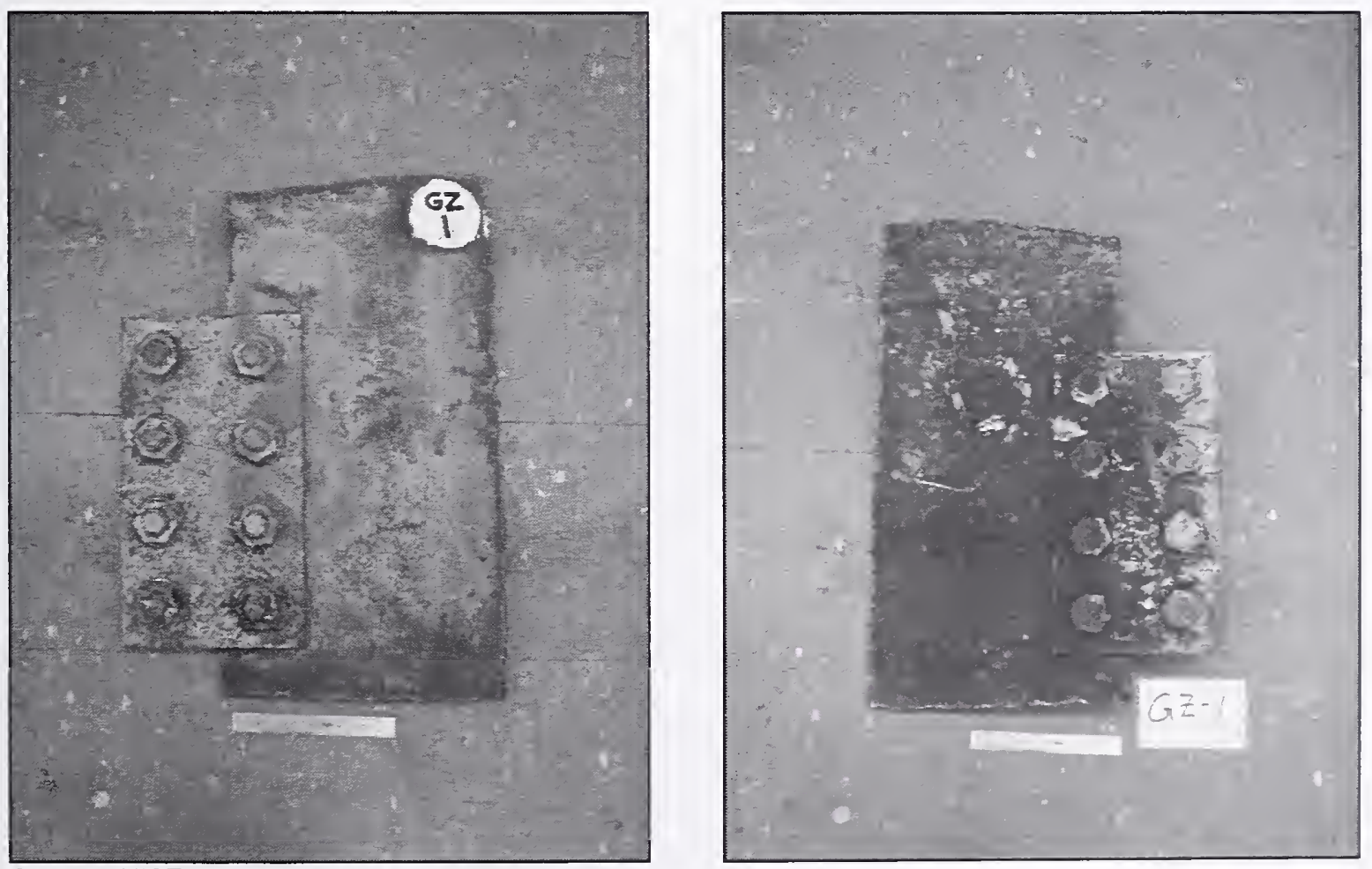

Source: NIST

Figure A-12. Coupons removed in the field from WTC 5; shown is sample GZ-1. 

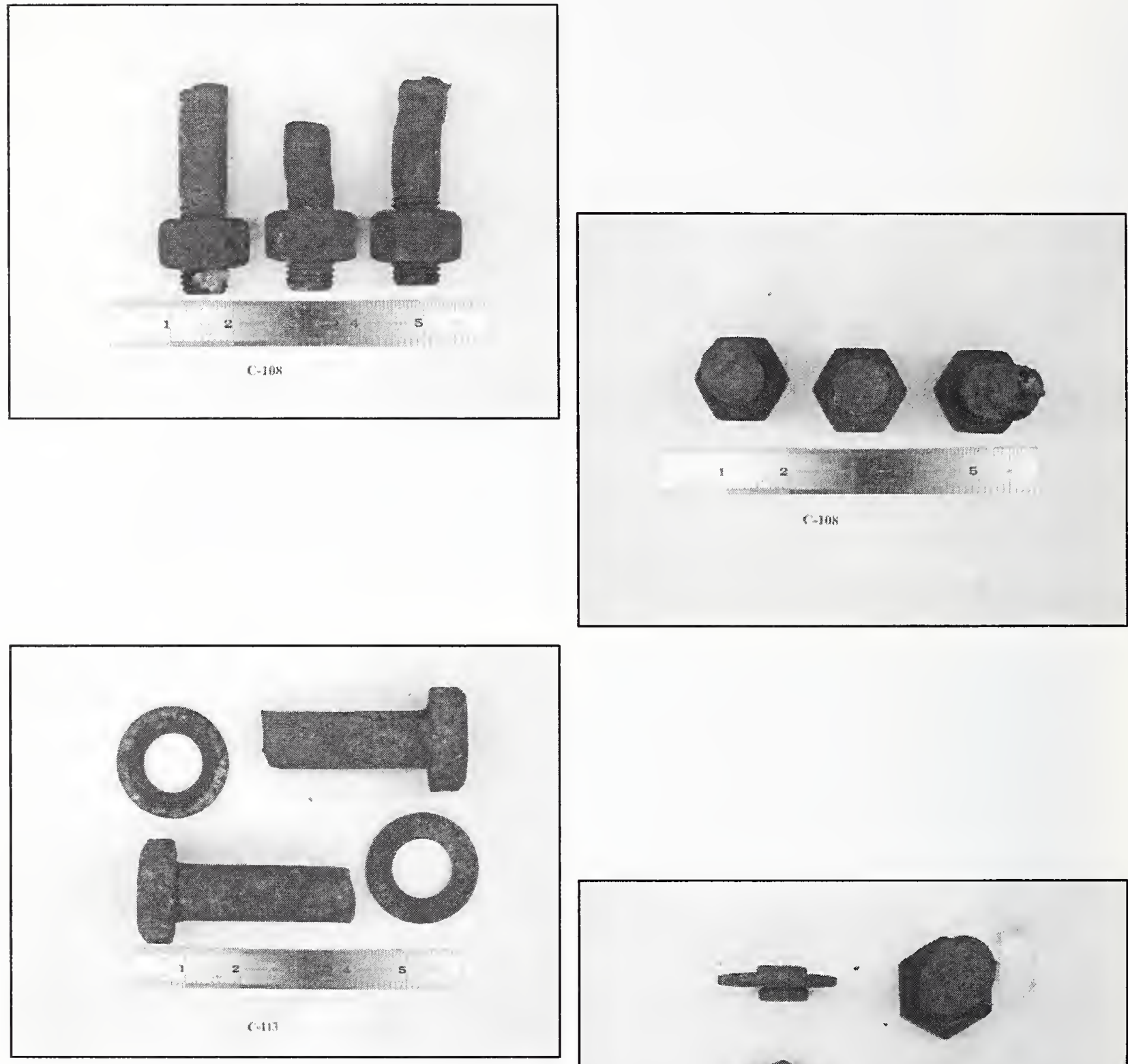

Source: NIST.

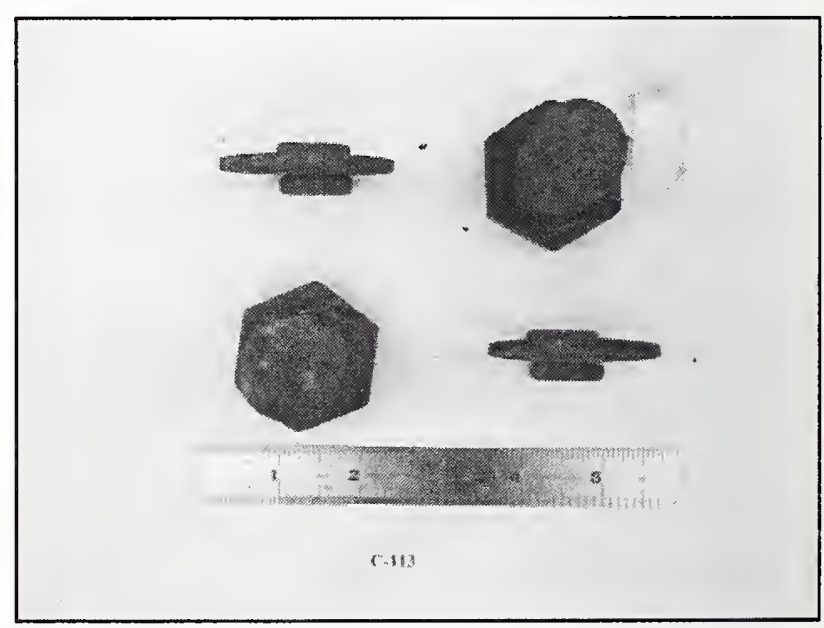

Figure A-13. Examples of recovered bolts from various samples. 


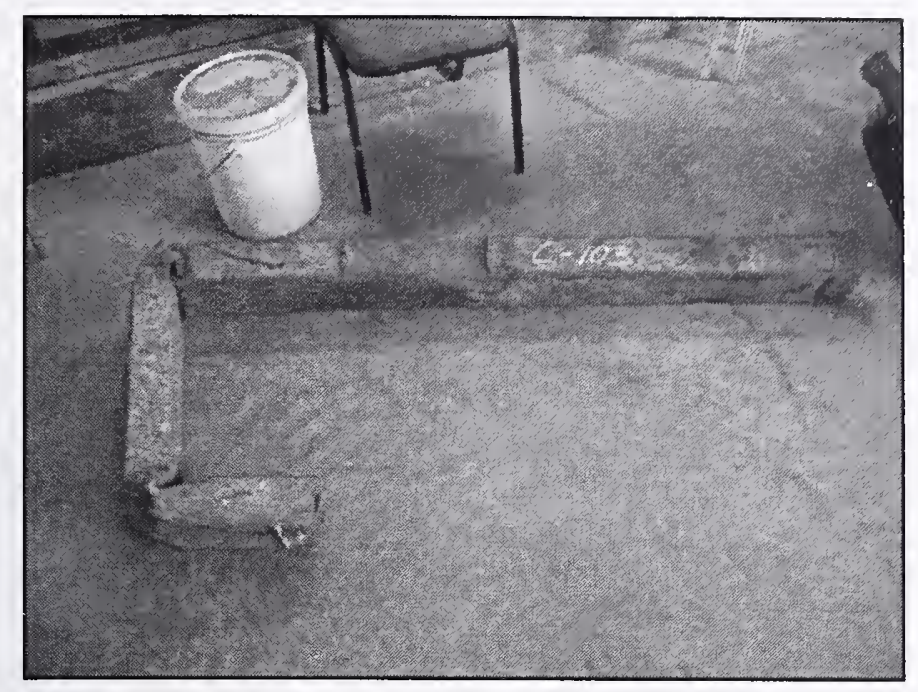

Square tubular piece

Sample C-103

Rectangular tubular piece

Sample C-135
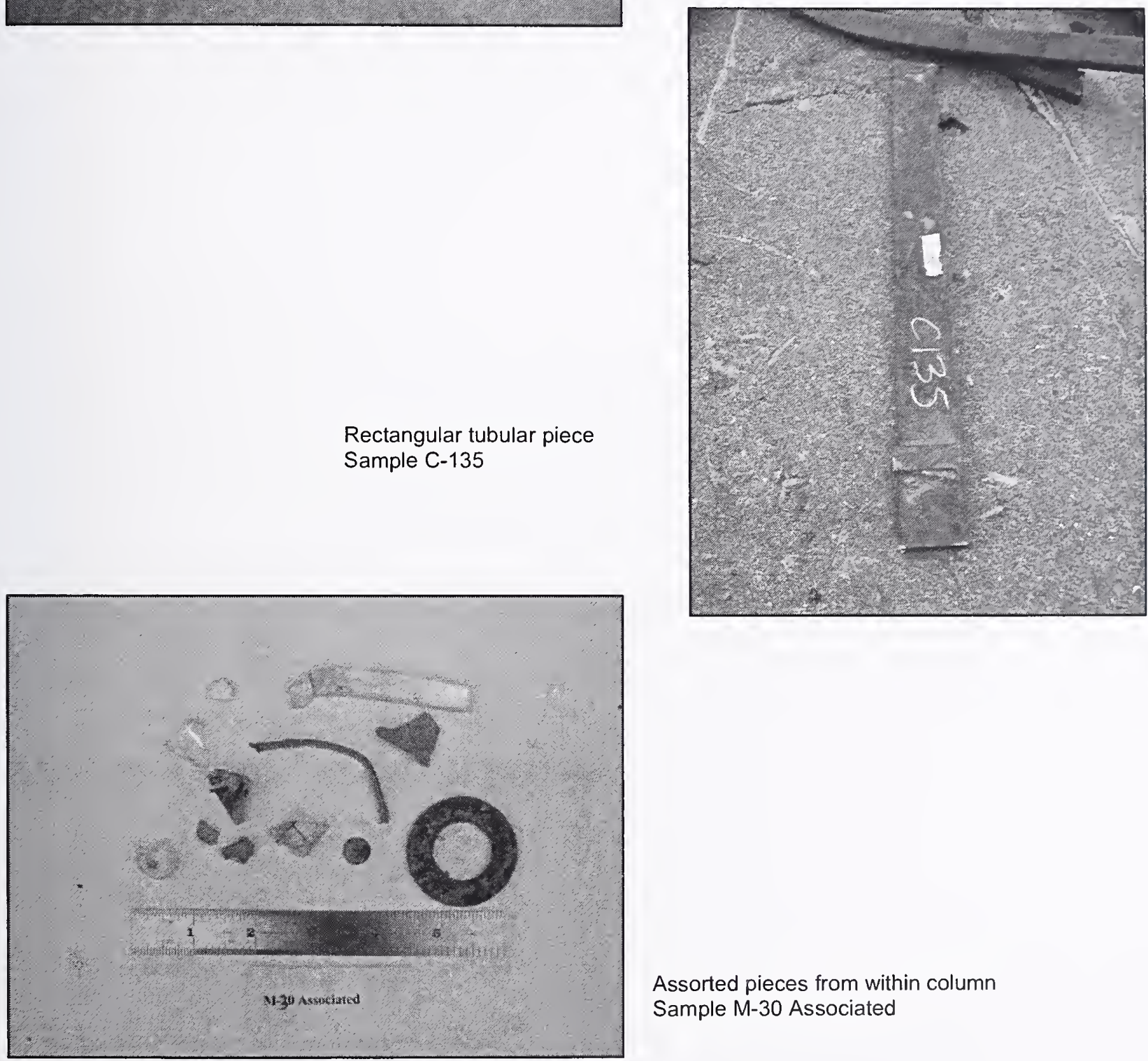

Assorted pieces from within column Sample M-30 Associated

Source: NIST.

Figure A-14. Examples of miscellaneous materials recovered. 
This page intentionally left blank. 



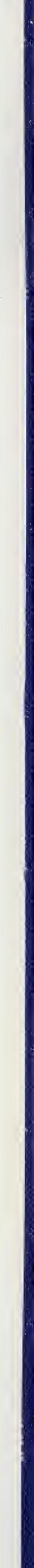

